FEDERAL RESERVE BANK OF SAN FRANCISCO

WORKING PAPER SERIES

\title{
Does Greater Inequality Lead to More Household Borrowing? New Evidence from Household Data
}

\author{
Olivier Coibion \\ UT Austin and NBER \\ Yuriy Gorodnichenko \\ UC Berkeley and NBER \\ Marianna Kudlyak \\ Federal Reserve Bank of San Francisco \\ John Mondragon \\ Northwestern University \\ August 2016 \\ Working Paper 2016-20 \\ http://www.frbsf.org/economic-research/publications/working-papers/wp2016-20.pdf
}

\section{Suggested citation:}

Coibion, Olivier, Yuriy Gorodnichenko, Marianna Kudlyak, John Mondragon. 2016. "Does Greater Inequality Lead to More Household Borrowing? New Evidence from Household Data" Federal Reserve Bank of San Francisco Working Paper 2016-20.

http://www.frbsf.org/economic-research/publications/working-papers/wp2016-20.pdf

The views in this paper are solely the responsibility of the authors and should not be interpreted as reflecting the views of the Federal Reserve Bank of San Francisco or the Board of Governors of the Federal Reserve System. 


\title{
Does Greater Inequality Lead to More Household Borrowing? New Evidence from Household Data
}

\author{
Olivier Coibion \\ UT Austin and NBER \\ ocoibion@austin.utexas.edu \\ Marianna Kudlyak \\ Federal Reserve Bank of San Francisco \\ marianna.kudlyak@sf.frb.org
}

\author{
Yuriy Gorodnichenko \\ UC Berkeley and NBER \\ ygorodni@econ.berkeley.edu \\ John Mondragon \\ Northwestern University \\ john.mondragon@kellogg.northwestern.edu
}

First Draft: December, 2013

This Draft: August, 2016

\begin{abstract}
Using household-level debt data over 2000-2012 and local variation in inequality, we show that low-income households in high-inequality regions (zip-codes, counties, states) accumulated less debt (relative to their income) than low-income households in lower-inequality regions, contrary to the prevailing view. Furthermore, the price of credit is higher and access to credit is harder for low-income households in high-inequality versus low-inequality regions. Lower quantities combined with higher prices suggest that the debt accumulation pattern by household income across areas with different inequality is a result of credit supply rather than credit demand. We propose a lending model to illustrate the mechanism.
\end{abstract}

JEL: E21, E51, D14, G21

Keywords: inequality, household debt, credit, income, Great Recession

We are grateful to Meta Brown, Donghoon Lee, and seminar participants at the CES-Ifo, Cologne, CREI, Boston College, LBS, NBER SI ME and EFACR, Rice, SED in Toronto, Tinbergen Institute, U. of Houston, VCU, FRB New York, FRB Richmond, FRB St. Louis, FRB San Francisco, FRB Philadelphia Payments Center, FR Board, Bank of Netherlands, European University Institute, EEA-ESEM in Toulouse, EEA-ESEM in Mannheim, BYU Red Rock Conference in Utah, IBEFA conference in Denver for helpful comments. The views expressed here are those of the authors and do not reflect those of the Federal Reserve Bank of San Francisco or the Federal Reserve System or any other institution with which the authors are affiliated. Mondragon thanks the Richmond Fed for their generous support while part of this paper was written as well as support from the NSF. Gorodnichenko thanks the NSF and Sloan Foundation for financial support. 


\section{Introduction}

The financial crisis of 2008-09 was preceded by an exceptional rise in borrowing by U.S. households, which had been on a rise since the 1980s. Over the same period, income inequality in the U.S. increased to the highest levels seen in the post-war period (see Figure 1). These striking movements motivate a question about a possible link between the two trends, and, in particular, whether the rise in income inequality may have caused some of the increase in household leverage.

Establishing a causal link has proven challenging for modern theories of consumption and income. A large literature documents that the rising inequality is a result of permanent changes of incomes rather than temporary increases in income volatility; ${ }^{1}$ standard theory then predicts that households facing permanent declines in income should adjust their consumption downwards and curb their borrowing. To rationalize the increase in household debt, the literature has called for alternative consumption theories and explanations: keeping up with the rich/Joneses (Veblen, 1899), expenditure cascades (Frank, Levine, and Dijk, 2014), a need to sustain past living standards (Stiglitz, 2009), or government incentives to lenders for expanding credit to low-income groups (Rajan, 2010). Implicit in these mechanisms is an assumption that the increased debt is mainly driven by lowerincome households. ${ }^{2}$ The assumption also appears in-line with the prevailing view of the role the lowincome/subprime segment in the 2008-09 crisis. $^{3}$ Despite the issue being at the heart of the debate regarding the 2007-09 crisis, no evidence exists on how household debt accumulations across income groups varies with income inequality.

In this paper, we study how household debt accumulation varied with income inequality over 2000-2012. Is it the case that poorer households accumulated more debt when faced with higher inequality? We use nationallyrepresentative household-level U.S. credit bureau data from the New York Federal Reserve Bank Consumer Credit Panel/Equifax (CCP) which provide comprehensive panel data on debt for millions of U.S. households since 1999. First, we exploit cross-sectional variation in income inequality (zip codes, counties and states) and examine how household debt accumulation (relative to income) varied with a household's relative standing in the local income distribution and local income inequality. Our estimation of the evolution of household debt is akin to a "differencein-differences” approach across income groups and regional inequality levels. Considerable cross-sectional variation in local inequality allows us to conduct numerous subsample and robustness checks to isolate the role of inequality from other potential local influences. ${ }^{4}$ Second, we use loan application data from Home Mortgage

\footnotetext{
${ }^{1}$ See, for example, Moffitt and Gottschalk (2002, 2008), Sablehaus and Song (2009), Kopczuk, Saez, and Song (2010), Piketty and Saez (2013).

${ }^{2}$ A long line of behavioral thought rationalizes income dispersion effects on household debt through "keeping up" motives. As inequality increases, high-income households are able to consume relatively more than low-income households. If low-income households experience a disutility from not consuming equivalent amounts as high-income households, they might try to maintain a higher level of consumption, potentially funded by debt.

${ }^{3}$ See, for example, Mian and Sufi (2009), Demyanyk and Van Hemert (2011), Keys, Mukherjee, Seru, and Vig (2010), and Mian and Sufi (2014), among others.

${ }^{4}$ Furthermore, much of the rise in income inequality in the U.S. since the 1970s reflects a rise in inequality within regions rather than inequality across regions.
} 
Disclosure Act (HMDA) and examine how credit prices-interest on loans and access to credit—varied across regions with different local inequality for households with different incomes.

In contrast to the prevailing view, we find that lower-income households accumulated less debt in highinequality regions than lower-income households in low-inequality regions. Furthermore, we find that the price of credit is higher and the access to credit is harder for low-income borrowers in high inequality areas than for low-income borrowers in low inequality regions. Lower quantities combined with higher prices suggest that the patterns of debt accumulation by household income across areas with different inequality are likely a results of credit supply rather than a credit demand mechanism. To demonstrate the mechanism, we present a simple lending model in which lenders use household position in local income distribution and local inequality to draw inferences about borrowers' types.

Our work is the first to challenge the prevailing narrative of the 2007-09 financial crisis by which the growth in debt was driven by low-income/subprime borrowers. ${ }^{5}$ Consistent with modern theories of consumption, we find no evidence of low-income households driving the debt increase when faced with higher inequality and our results are broadly consistent with new evidence that consumption inequality is in fact mirroring income inequality (Aguiar and Bils, 2015). Our results find no evidence of banks disproportionately expanding credit to the low-income households which are typically high risk.

As a side-product of our analysis, we develop a novel, reliable income imputation procedure for the credit bureau data. Specifically, while the CCP data provide detailed debt and location information, they do not contain information on income. Our imputation procedure exploits the relationship between household debt and income in the Survey of Consumer Finances. We demonstrate that our imputation is robust and capable of recovering local income distribution statistics with high accuracy. The imputation allows the study of the relationship between income and debt in an unprecedented detail and thus significantly increases the scope of the CCP.

The results that low-income households in high-inequality regions borrowed relatively less than lowincome households in low-inequality regions are robust to using different subsamples and specifications. The results hold within households with low or high credit scores, within regions which experienced either high or low home price appreciation, within households with either low or high initial debt levels, etc.; they hold across different levels of aggregation (zip code, county, and state) and are robust to controlling for a wide range of other local factors that are potentially correlated with inequality levels.

In addition to total household debt, we also examine the evolution of different forms of debt. We find that low-income households in high-inequality regions borrowed less in terms of both mortgage and auto debt than those in low-inequality regions, implying that our results are not driven entirely by local housing markets. Lowincome households in high-inequality regions also saw their credit limits rise by less than those in lower inequality regions. However, no economically significant heterogeneity is observed in credit card balances. Since lenders

\footnotetext{
${ }^{5}$ Our findings are echoed in the subsequent emerging studies by Adelino, Schoar, and Severino (2015), Gropp, Krainer, and Laderman (2014), Agarwal, Chomsisengphet, Mahoney, and Stroebel (2015), among others.
} 
have less control over credit card balances than over mortgage credit, auto credit or credit card limits, we interpret this result as providing evidence that the differences in household debt between low income households in high versus low inequality regions are driven by supply factors.

Our results on how credit prices and credit access vary with local inequality come from detailed data from mortgage applications and bank branch location. First, low-income households in high-inequality regions were more likely to be denied when applying for a mortgage relative to low-income households in low-inequality regions. Second, low income households were more likely to be charged higher interest rates for their mortgages relative to the low income households in low-inequality regions. Finally, lender branches are physically closer to high-income borrowers in high-inequality regions relative to similar households in low-inequality regions; and banks opening a branch are more likely to place that branch in a high-income neighborhood as local inequality increases.

Our empirical results show that as local inequality increases, the supply of credit to low-income households declines: these households borrow less at a higher cost. We present a simple lending model to illustrate the mechanism. In the model, high-type households have higher income on average than low-type households and are also less likely to (exogenously) default on debt. Banks in each region lend to these households but they do not observe households’ types, only their income and another signal correlated with the underlying type. As income inequality rises, banks treat an applicant's income as an increasingly precise signal about their type and therefore target lending toward higher-income households on average. How they do so, however, can vary with the local banking structure. For example, if banks are perfectly competitive and can charge different interest rates to different applicants, then higherincome applicants will on average face lower interest rates than low-income applicants, and this difference will be increasing in the amount of local income inequality. If instead we model the banking system as being monopolistic and forced to charge a common interest rate to all applicants, then this bank will reject low-income applicants more frequently than high-income applicants, and this difference will again be increasing in the amount of local inequality. In both cases, banks will make credit more accessible (or cheaper) to high-income households when local inequality is higher since income is a more precise signal of applicant types. Intuitively, as the income distribution becomes more dispersed it becomes easier for local creditors to differentiate between high- and low-quality borrowers. This allows lenders to offer cheaper credit to high-income households or, similarly, to charge low-income households more. This credit supply mechanism qualitatively matches the observed behavior of credit quantities and prices across households of different income and across locations with different inequality levels.

This paper relates to research investigating the macroeconomic consequences of income inequality and its link to financial crises. Kumhof et al. (2015), for example, argue that a rise in inequality driven by an increase in the share of income going to those at the top of the income distribution induces the latter to save more, lowering interest rates and inducing poorer households to borrow more, ultimately leading to more financial fragility and a higher likelihood of a financial crisis. Bordo and Meissner (2012) find little evidence of such a link based on aggregate data since 1920 for fourteen advanced economies, whereas Perugini et al. (2013) find a positive link between income inequality and private sector indebtedness since 1970 across eighteen economies. We contribute to this literature by documenting how, 
within U.S. regions, debt accumulation patterns across different segments of the population over the course of the 2000s were systematically related to local levels of income inequality. We also provide a novel interpretation for these effects: local income inequality can be used in combination with an applicant's income level to refine inference about borrower types. Higher levels of income inequality then induce banks to reallocate credit toward higher-income applicants and away from lower-income applicants, thereby potentially amplifying the implications of a more unequal income distribution for the distribution of consumption.

The relationship between income inequality and the allocation of credit emphasized in our paper also relates to the literature on consumption and income inequality. Our findings are consistent with Aguiar and Bils (2015) who argue that consumption inequality has tracked income inequality closely over the last three decades. In addition, there is a large literature documenting that rising consumption of the rich induces the non-rich to consume more. ${ }^{6}$ Our results show that these effects nevertheless do not generate differences in debt, and thus the documented differences in consumption are likely financed through channels other than debt, i.e., through increased labor force participation, longer working hours, etc. We also contribute to the vast literature on household borrowing that covers such diverse topics as pricing of mortgages, optimal portfolios of household debt, risk scoring, and determinants of default probabilities. Our paper is most related to studies of default determinants (e.g., Fay et al. 2002, Gross and Souleles 2002) and lenders' treatment of loan applications (e.g., Tootell 1996, Munnell et al. 1996, Turner and Skidmore 1999) in the sense that we attempt to understand who obtains credit and at what terms. However, while previous research studied these aspects for borrowers without relating a given individual to the pool of borrowers, we explicitly focus on how the relative positions of borrowers in the income distribution as well as the properties of the income distribution can affect the level of debt that households ultimately accumulate. Thus, in contrast to the previous literature, we examine directly the interplay between debt and inequality, which has been the subject of recent policy and academic debates.

This paper is structured as follows. We describe our primary source of data in Section 2 as well as our novel imputation procedure for income. In Section 3, we present household-level regressions describing the differential debt accumulation patterns across income levels in regions with different levels of income inequality. Section 4 examines the relationship between credit prices and access using data on mortgage applications, branch location, and local inequality. In section 5, we present a simple model that can rationalize these patterns. Section 6 concludes.

\section{Data}

In this section, we first describe the dataset used to measure household debt accumulation over the course of the 2000s. Second, we discuss how we impute household income based on observed patterns in the Survey of Consumer Finances. Third, we construct local income inequality measures and describe some of their properties.

\footnotetext{
${ }^{6}$ The evidence of such effects are provided by Bertrand and Morse (2013) includes Neumark and Postlewaite (1998), Zizzo and Oswald (2001), Christen and Morgan (2005), Luttmer (2005), Daly and Wilson (2006), Maurer and Meier (2008), Charles et al. (2009), Kuhn et al. (2010), Heffetz (2011), and Guven and Sorensen (2012).
} 


\subsection{The New York Federal Reserve Bank Consumer Credit Panel/Equifax}

We measure household debt accumulation using the New York Federal Reserve Bank Consumer Credit Panel/Equifax (CCP) data. The CCP is a quarterly panel of individuals with detailed information on consumer liabilities, delinquency, some demographic information, credit scores, and geographic identifiers to the zip level. ${ }^{7}$ The core of the database constitutes a 5\% random sample of all U.S. individuals with credit files. The database also contains information on all individuals with credit files residing in the same household as the individuals in the primary sample. The household members are added to the sample based on the mailing address in the existing credit files. Using the households' identifiers, we aggregate individual records into households' records and construct measures of households' debt. The resulting sample is a quarterly sample of U.S. households in which at least one member has a credit file. We use $100 \%$ of the CCP sample. ${ }^{8}$ The data cover all major categories of household debt including mortgages, home equity lines of credit (HELOC), credit cards, and student loans. Because of the large sample size, the breadth of variables observed, detailed location, and the ability to construct a quarterly household panel these data provide the most detailed picture of household debt available.

\subsection{Income Rank Imputation}

While the CCP provides detailed records of household debt and geographical location, it does not include information on household income. To address this issue, we impute income for the households in the CCP using information from the Survey of Consumer Finances (SCF). The SCF is a household-level survey that contains information on debt balances and income as well as a rich set of demographic characteristics. However, the SCF does not provide geographic identifiers in the publicly available data. We use the SCF to estimate how household income relates to debt and demographic characteristics available in both the CCP and SCF data sets. We then use these estimates to impute household income in the CCP data. Finally, we use the imputed income and the estimated error terms from the SCF to impute the household's income rank in the household's geographical area and the distribution of income in that area.

In our analysis, we restrict the sample to households for whom the household head's age is between 20 and 65 to minimize potential age-related selection effects. The data in the CCP are updated quarterly. We use data from the third quarter of the CCP for years 2001 - 2012. We follow Brown et al. (2011) and choose the third quarter to maximize the match with the SCF survey (typically administered between April and December). For consistency, we then use the third quarter of each subsequent year to generate annual measures of household debt.

Table 1 contains the summary statistics from the CCP and SCF samples from the third quarter of 2001. The statistics from the CCP and SCF are similar for most categories with the exception of credit card balances. This finding is consistent with Brown et al. (2011) reporting that overall and in the majority of disaggregated debt categories (mortgages, auto loans, and HELOCs), borrower characteristics and debt levels reported in the CCP and SCF are similar. Brown et al. (2011) suggest that some of the discrepancy between the credit card balance

\footnotetext{
${ }^{7}$ For complete details on the data set and variables construction, see Appendix B.

${ }^{8}$ Lee and van der Klaauw (2010) provide a detailed description of the database.
} 
statistics in the two datasets might come from the way credit card balances are recorded: the CCP contains records of all credit card balances, whereas the households in the SCF might only report the fraction of the balance they intend to roll over. ${ }^{9}$ The mortgage balance and HELOCs in the CCP are slightly higher than in the SCF because the CCP measure includes secondary/investment properties, while in the SCF it does not (see Brown et al. 2011). The auto debt balance is also slightly higher in the CCP because the CCP includes auto leases, while in the SCF respondents do not necessarily report car leases as auto debt. The bankruptcy rates are very similar between the two samples. The tables also show some differences between the delinquency statistics in the two datasets. It is possible that SCF households only report severe delinquencies on large quantities of debt and do not report delinquencies that they regard as temporary or small. ${ }^{10}$

To impute the rank in the income distribution for a household in the CCP, we first estimate the following relationship between the household's gross income and observable characteristics in the 2001 SCF,

$$
\log \left(Y_{i, S C F}\right)=\beta f\left(X_{i, S C F}\right)+\epsilon_{i, S C F}
$$

where $Y_{i, S C F}$ is the income of household $i$, and $X_{i, S C F}$ is the vector of the household's characteristics that include (logs of) mortgage balance, credit card balance, credit card limit, an indicator for positive credit card limit, the credit card utilization rate conditional on positive credit card limit, auto loan balance, HELOC balance, student loan balance, an indicator for bankruptcy, an indicator of 60 days or more past due on any loan, the age of the head of the household and the household size. $f($.$) is a vector-valued function that includes polynomials,$ interaction terms, and dummy variables. Appendix F provides more information on the specification and variables. We estimate equation (1) using OLS (with the SCF sampling weights) and eliminate outliers using Cook's distance. ${ }^{11}$ The unadjusted $R^{2}$ for this regression is 0.55 .

Using the estimated $\beta$, we construct the expected imputed (log) income for each household $i$ in the third quarter of 2001 in the CCP data:

$$
\mathrm{E}\left[\log \left(Y_{i}\right)\right]=\hat{\beta} f\left(X_{i, C C P}\right),
$$

and the expected imputed income (in levels)

$$
\mathrm{E}\left[Y_{i}\right]=\exp \left[\mathrm{E}\left[\log \left(Y_{i}\right)\right]+0.5 \sigma_{\hat{\epsilon}_{i, S C F}}^{2}\right]
$$

where $\sigma_{\hat{\epsilon}_{i, S C F}}^{2}=0.423$ is the variance of $\epsilon_{i, S C F}$ estimated in equation (1).

\footnotetext{
${ }^{9}$ In the CCP, the credit balance is recorded on some date during the quarter. For some individuals, this can be the date right before they pay off most of their credit balance, and the balance might largely reflect the transaction use of the credit cards. For other individuals, the date might be the date after they pay off the intended balance and the remaining amount reflects the carry-over balances. In the SCF, the credit balance reported likely does not reflect the use of credit card for transactions, but rather the debt that the household does not plan to repay in the current period. In addition, the households in the SCF might forget older balances.

${ }^{10}$ In the SCF data, the 60DPD indicator is the indicator of whether a household has ever been delinquent on any loan for 60 days or longer. In the CCP data, the 60DPD indicator is the indicator of whether a household is delinquent on any loan for 60 days or longer in the current quarter.

${ }^{11}$ Equation (1) is estimated only for observations with positive values of income. We also restrict our analysis to the 50 U.S. states and the District of Columbia, dropping the observations from Puerto Rico and U.S.-owned territories.
} 
Having imputed households' incomes in the CCP, we then estimate the household's rank in the local income distribution. For each household $i$ in area $c$ we construct its income rank in 2001, $R_{i, c, 2001}$, as the rank of the household's expected imputed income, $\mathrm{E}\left[\log \left(Y_{i, 2001}\right)\right]$, in the imputed income distribution for location $c$. We approximate the local income distribution through a resampling procedure. In particular, we assume that the distribution of income residuals estimated in the SCF is the same across all locations. Note that if this assumption is not appropriate, we will tend to bias our results against finding any role for inequality in accounting for debt dynamics. However, our results are robust to using alternative measures of inequality that do not rely on this imputation procedure, as illustrated in section 3.2. After drawing a household from location $c$ in the CCP and calculating its expected income, we add a randomly drawn residual estimated on the SCF sample to obtain a simulated household income:

$$
\log \left(Y_{i, c, C C P}\right)=\hat{\beta} f\left(X_{i, c, C C P}\right)+\hat{\epsilon}_{S C F} .
$$

By repeating the process 50,000 times, with draws done with replacement, we approximate the local income distribution. We then calculate each household's percentile rank $\left(R_{i, c, 2001}\right)$ using their expected income relative to the simulated distribution of incomes from that region. The higher the value of $R_{i, c, 2001}$, the relatively richer is household $i$ in its geographical location $c$ in 2001.

We separately construct the rank of the household by the household's location at the three different levels of aggregation: zip code, county, and state. When the measure is constructed at the zip code level, we restrict the analysis to zip codes with at least 100 households in our CCP sample. This gives us 14,529 distinct zip codes in 2001. At the county level, we restrict the analysis to counties with at least 300 households in our CCP sample. This procedure gives us 2,303 counties in 2001, covering over 35,000 zip codes.

The imputation is new and its reliability at relatively disaggregated geographic locations is not obvious since the SCF regression does not use geographic information. Therefore, we check the quality of our imputation in a number of ways. First, we can easily check the quality of the rank imputation within the SCF itself, although this does not speak to the quality of the imputation across geographies. Regressing the true percentile rank on the imputed rank and a constant gives us a coefficient of 0.69 with a robust standard error of 0.004, extremely significant. To test that the imputation is reliable across the income distribution, Table 2A presents the moments of the income distribution imputed in the CCP and the same moments calculated from the SCF. The two sets of moments are very similar, particularly away from the edges as one would expect.

Critically, our imputation does not use local information because it is not available in the public version of the SCF. Therefore, the quality of the imputation in the cross-section might be worse than the quality in the aggregate. While we cannot check how the quality of the imputation at the household level varies in the cross-section, we can examine slightly aggregated statistics. Figure 2 plots log 2001 county median household income from the Census against our imputed measure. Despite not using any local information in our training regression, the imputed and actual values are very closely related (correlation equal to 0.9 with a spearman correlation of 0.88 ). As with the aggregate statistics, the imputation performs worse at the edges of the distribution, overstating the incomes of counties with very low incomes and understating those with very high incomes. However, the relationship is remarkably tight. 
For a subset of households, we can examine the quality of our income imputation procedure directly by bringing household-level income information to the CCP data from an outside source. We merge the CCP data with the data from a proprietary database that has detailed mortgage-level panel data with information on a majority of mortgages originated in the U.S. Critically, these data include the debt-to-income ratio associated with each mortgage at the time of origination. We use information on the mortgage origination month, location (zip code) and balance from this proprietary database and the same attributes from the mortgage trade-line data in the CCP to match households in the two datasets as in Elul et al. (2010). The earliest year when the debt-to-income variable is available in the proprietary dataset and when the SCF is available is 2007; thus we merge the data using the first mortgages originated in 2007 and re-estimate our imputation equation for 2007. Prior to the merge, we eliminate all cases of multiple mortgages with the same combination of open month, initial balance and zip code in both datasets to ensure that the match is unique. For the sample of matched households we use the debt-to-income ratio from the proprietary database and the debt in the CCP to estimate the income. For this subset of matched households we compare the income rank derived from the proprietary data with the income rank derived from the SCF-CCP imputation. The two measures of rank are highly positively correlated (Spearman correlation is 0.55). Regressing the imputed CCP income measure on the actual measure of income yields a slope estimate that is practically one, consistent with a classical measurement error relationship between the two measures of income.

As described in more detail in section 3.3, we can also verify that our results are robust to using alternative imputed income measures from the Equifax Credit Risk Servicing McDash Dataset. These measures rely on a proprietary algorithm which, instead of using the SCF in the first step of the imputation, exploits a large national sample of employer-provided incomes to predict consumer incomes using credit bureau attributes. We summarize these results in Appendix H. Finally, to rule out systematic measurement error, we also check that the quality of our imputation does not vary with measured inequality, which we discuss in more detail in section 2.3.

\subsection{Local Inequality Measures}

Having imputed income in the CCP, we construct the local inequality measures for $2001\left(I_{c, 2001}\right)$. Our preferred measure of inequality is the difference between expected log income at the $90^{\text {th }}$ percentile and expected log income at the $10^{\text {th }}$ percentile, i.e.,

$$
I_{c, 2001}=p 90_{c}\left[E\left\{\log \left(Y_{i, c, 2001}\right)\right\}\right]-p 10_{c}\left[E\left\{\log \left(Y_{i, c, 2001}\right)\right\}\right] .
$$

We then compare this measure to inequality measures constructed from alternative sources. At the zip code level, we use data from the IRS on household adjusted gross income (AGI) drawn from the 2001 tax returns. At the county level, we use the Census data on household income from 2000. Both of these sources provide income bins and the fraction of the population within each bin. Using this information, we construct an approximation to the Gini coefficient. The CCP measure constructed from imputed incomes is highly correlated with Gini coefficients based on Census or IRS data. For example, the correlation between Gini coefficients from the 2000 Census and 90-10 differences in the CCP data at the county level is 0.59 . While these two alternative measures do not rely on income imputations, they have limitations (in addition to providing a different measure of inequality). The IRS and Census measures are based on 
income bins rather than actual incomes and therefore are imprecise measures of local inequality, especially for very high-income households and in areas with high incomes. In addition, Census data, which provide more detailed income bins, are only available at the county level. As a result, we rely primarily on our imputed income inequality measures in the analysis but verify that our results are robust to using these alternative measures of local inequality.

Figure 3 plots a map of U.S. inequality at the county level. Inequality is on average highest in the southern states, as well as California and the Pacific Northwest. Midwestern states, in contrast, stand out for having some of the lowest levels of inequality on average. The map also shows that inequality tends to be higher in large cities than in more rural areas. The map masks even greater regional heterogeneity in inequality at the zip code level. Figure 4 plots histograms of our CCP inequality measure at each level of aggregation. Average inequality is higher at lower levels of aggregation with a mean across zip codes of 2.24 and a mean of 1.68 across states. The standard deviation of inequality is twice as high (0.15) at the zip level compared to the state level (0.07).

We focus on local income inequality for a number of reasons. First, this is likely to be the most relevant metric when households compare themselves to others. Second, it avoids measurement issues associated with comparing incomes across very different areas (e.g. \$100K in New York vs. Tulsa). Third, much of the rise in aggregate inequality in the U.S. reflects rising inequality within regions rather than across regions. ${ }^{12}$ Finally, there is much more variation in income inequality across regions than in aggregate inequality over time, which is necessary for isolating any potential effects of inequality on household behavior (Figure 4).

For our analysis it is critical that the quality of the imputation is not correlated with local inequality. Otherwise we will systematically misstate household rank as inequality varies and so mistakenly compare households that do not actually have similar ranks. We cannot test this directly at the household level, but we can test if the quality of imputed ranks of counties varies with the level of inequality or across regions (Figure 3 showed that there was significant regional components to local inequality). Table 2B reports Spearman (or rank) correlations between actual and imputed median household income for subsets of counties split by measured inequality as well as by Census region. Strikingly, the correlation between the imputed and actual ranks is essentially invariant to local inequality (imputed or using Gini coefficients from the Census). Similarly, the correlation between actual and imputed county income is consistently strong across regions, varying between 0.83 and 0.87 . This suggests that the vast majority of the relationship between observables and income that our imputation relies on is invariant to the local income distribution.

\section{Empirical Analysis of Debt and Inequality}

In this section, we investigate how households' borrowing patterns from 2001 to 2012 varied with local inequality. We do so using household-level regressions of debt-to-income changes over time as a function of household

\footnotetext{
${ }^{12}$ In Appendix C, we describe in detail a decomposition of aggregate income inequality in the U.S. from 1970 to 2000 measured using Census income data. When we measure the relative importance of differences in mean incomes across regions ("between" inequality) versus the dispersion of incomes within regions ("within" inequality) for each Census, we find that "between" inequality has consistently accounted for less than two percent of total inequality and that this share has, if anything, been declining over time.
} 
characteristics, their position in the local income distribution, and interactions of the latter with local inequality measures. We find that local inequality is associated with differences in debt accumulation for households with different incomes. Specifically, low-income households borrow relatively less in high-inequality areas than lowincome households in low-inequality areas. We document the robustness of this result along a variety of dimensions.

\subsection{Baseline Results}

We are interested in estimating the role of local income inequality in the relationship between a household's debt accumulation and their rank in the initial local income distribution. In particular, we estimate the change in each household's debt between 2001 and year $t, 2002 \leq t \leq 2012$, as a function of their income rank in the 2001 local income distribution, conditional on local income inequality in 2001. The benchmark specification is

$$
\frac{\Delta D_{i c t}}{E[Y]_{i c, 2001}}=\alpha R_{i c, 2001}+\beta I_{c, 2001}+\gamma R_{i c, 2001} \times I_{c, 2001}+c^{+}+\epsilon_{i c t},
$$

where $\frac{\Delta D_{i c t}}{E[Y]_{i c, 2001}}$ is the change from year 2001 to year $t$ in the debt of household $i$ that resides in location $c$ relative to the household's (imputed expected) income in 2001 (in levels), i.e., $\frac{\Delta D_{i c t}}{E[Y]_{i c, 2001}} \equiv \frac{D_{i c t}-D_{i c, 2001}}{E[Y]_{i c, 2001}}$, where $D_{i c t}$ is deflated by the CPI-U and expressed in 2001 dollars. $c^{+}$is a fixed effect of the geographical location that is at one level of aggregation higher than the geographic area used to construct the income distribution and the income inequality measure. ${ }^{13}$ We use the 2001 measure of local income inequality because it is predetermined relative to subsequent household debt accumulation decisions, although inequality is highly persistent over time (see Appendix D).

Parameters $\alpha, \beta$ and $\gamma$ describe the relationship between a household's debt accumulation and local inequality. If $\alpha<0$, low-rank households within an area accumulate relatively more debt than high-rank households. If $\beta=\gamma=0$, then local inequality is irrelevant for household debt accumulation. This case is shown in Panel A of Figure 5. Panel B of Figure 5 illustrates the case when $\alpha<0, \beta>0, \gamma<0$. If $\beta>0$, an area with higher inequality is associated with higher debt accumulation. If $\gamma<0$, this effect weakens as household rank increases. The final panel illustrates a case where $\gamma>0$. In this case there is a crossing point such that to the right high-income households accumulate more debt as inequality increases. To the left of this crossing point lowincome households accumulate less debt as inequality increases. The aggregate effect depends on the exact crossing point and relative slopes.

We estimate equation (2) separately for each year $t, 2002 \leq t \leq 2012$. In each year $t$, we follow Guerrieri et al. (2013) and restrict the sample to households that reside in the same geographical area $c$ in 2001 and in $t$. In

\footnotetext{
${ }^{13}$ For example, in the regressions with zip code-level distribution of income and inequality, we control for county-level fixed effects. In the regressions with county-level rank and inequality, we control for state-level fixed effects. We do not control for the geographical fixed effects in the regressions with state-level income rank and inequality.
} 
each regression, we exclude the observations below the $2^{\text {nd }}$ and above the $98^{\text {th }}$ percentile of the distribution of $\frac{\Delta D_{i c t}}{E[Y]_{i c, 2001}}$ in year $t$. The standard errors are clustered by geographic location $c .^{14}$

Our baseline estimates of equation (2), estimated at the zip code level with county fixed effects for years ranging from 2002 to 2012, are reported in Panel A of Table $3 .{ }^{15}$ Our first finding is that the coefficient on a household's rank in the income distribution $(\alpha)$ is consistently negative, with a peak absolute value in 2007. Hence, debt accumulation over the course of the early to mid-2000s was, on average, greater for lower-income households. Second, the estimated coefficient on the inequality level of the zip code is systematically negative, again peaking in absolute value in 2007. This implies that, holding everything else constant, households living in the more unequal areas within a county accumulated less debt over the early to mid-2000s than did those in lower inequality areas in the same county.

The key parameter for us is $\gamma$, which captures the interaction of household rank in the local income distribution and local inequality. Our main finding is that $\gamma$ is positive over this time period. This implies that debt accumulation was relatively higher for (sufficiently) high-income households in high-inequality regions than in lowinequality regions, or equivalently that lower-income households in high-inequality regions borrowed relatively less than their counterparts in lower inequality regions. Panel C of Figure 5 describes our results qualitatively. Households with rank to the right of the crossing accumulate more debt on average as inequality increases. Households to the left of the crossing accumulate relatively less debt as inequality increases.

To give a sense of the economic magnitudes, we calculate the change in debt accumulation in response to a one standard deviation increase in local inequality for households of several different ranks. Panel A of Figure 6 plots these calculated effects at the $80^{\text {th }}, 50^{\text {th }}$, and $20^{\text {th }}$ percentiles for each time sample. At the $80^{\text {th }}$ percentile a one standard deviation increase in inequality implies an increase in household debt over expected income of more than nine percentage points in 2007. At the $20^{\text {th }}$ percentile we estimate that households decreased debt relative to income by a little over seven percentage points in 2007. In the same year, the median household saw an increase in debt-to-income of little more than one percentage point.

\subsection{Specifications with Additional Controls}

Our baseline specification does not include any household-specific controls other than their rank in the income distribution. To control for potentially confounding household characteristics, we consider an expanded specification augmented to include a vector of household-specific regressors:

$$
\frac{\Delta D_{i c t}}{E[Y]_{i c, 2001}}=\alpha R_{i c, 2001}+\beta I_{c, 2001}+\gamma R_{i c, 2001} \times I_{c, 2001}+\psi X_{i c}+c^{+}+\epsilon_{i c t},
$$

where $X_{i c}$ is the set of household-specific controls. The latter include the age of the head of the household, household size, (logarithm of) the level of household's mortgage debt, (logarithm of) the level of household's auto

\footnotetext{
${ }^{14}$ Each specification below is estimated using household sampling weights from 2001, as described in Appendix B.

${ }^{15}$ In general we report standard errors uncorrected for the fact that rank and inequality are generated regressors. The standard errors are very similar but extremely computationally burdensome when we use a bootstrap to correct for the generated regressor.
} 
debt, (logarithm of) the level of household's HELOC debt, (logarithm of) the level of household's student loan debt, an indicator for a non-zero credit card debt limit, (logarithm of) the level of household's credit card debt, (logarithm of) the level of household's credit card limit, the credit card utilization rate conditional on non-zero credit card limit, default indicators, and the average of household members' credit scores. All controls are from 2001, with the exception of credit scores for which we include both 2001 values (to control for initial access to credit) as well as year $t$ values (to control for access to credit in subsequent years). Results from this augmented specification are presented in Panel B of Table 3. The results for the estimated effects of rank, inequality, and the interaction of the two are almost identical to those from the parsimonious specification.

We then include an additional vector of zip-level control variables:

$$
\frac{\Delta D_{i c t}}{E[Y]_{i c, 2001}}=\alpha R_{i c, 2001}+\beta I_{c, 2001}+\gamma R_{i c, 2001} \times I_{c, 2001}+\psi X_{i c}+\kappa W_{c}+c^{+}+\epsilon_{i c t},
$$

where $W_{c}$ is the set of location-specific controls. The set of location-specific controls includes the median expected income in the zip code in 2001, the median of (log of) the household's total debt in 2001, and the median of (log of) the household's mortgage debt in 2001. Results are presented in Panel C of Table 3. Again, our baseline estimates of the effects of household rank, local inequality and their interaction are almost unchanged. This is also illustrated graphically in Panel B of Figure 6: our estimates with both household and regional controls suggest that increasing inequality by one standard deviation is associated with households at the $80^{\text {th }}$ percentile increasing borrowing relative to income by almost 11 percentage points, at the $50^{\text {th }}$ percentile households increase borrowing over income by over one percentage point, and at the $20^{\text {th }}$ percentile households decrease borrowing over income by about eight percentage points. The difference between high- and low-rank households is essentially identical.

Another way to control for regional characteristics is to estimate our baseline specification with fixed effects at the level of the zip code rather than the county:

$$
\frac{\Delta D_{i c t}}{E[Y]_{i c, 2001}}=\alpha R_{i c, 2001}+\gamma R_{i c, 2001} \times I_{c, 2001}+\psi X_{i c}+\delta_{c}+\epsilon_{i c t} .
$$

With zip code-specific fixed effects $\delta_{c}$, we can no longer separate the effect of local inequality from other regional characteristics, but we can still estimate the coefficient on the interaction term between the household's income rank and local inequality, $\gamma$. The results from estimating equation (5) are presented in Panel D of Table 3: the estimate of $\gamma$ is again almost unchanged relative to those from our parsimonious specification (2) or specifications augmented with household (3) and regional controls (4).

We also check for omitted variable bias in the interaction term by adding the interaction of the household credit risk score with local inequality to the specification in equation (3). Specifically, this deals with the concern that income might be a proxy for some other variable actually driving debt accumulation. If the measure of income rank primarily picked up the relative importance of the household's credit risk score, the estimate of $\gamma$ should differ significantly after including this interaction. We estimated the following modification of specification (3):

$$
\begin{aligned}
\frac{\Delta D_{i c t}}{E[Y]_{i c, 2001}}=\alpha & R_{i c, 2001}+\beta I_{c, 2001}+\gamma R_{i c, 2001} \times I_{c, 2001}+\psi X_{i c} \\
& +\phi \operatorname{Risk}_{i c, 2001}+\sigma \operatorname{Risk}_{i c, 2001} \times I_{c, 2001}+c^{+}+\epsilon_{i c t},
\end{aligned}
$$


The estimates of $\gamma$ across all years (Panel A, Table 4) are robust to the inclusion of the interaction term.

Similarly, we check whether the results are sensitive to including an interaction of the household's initial debt level with local inequality in specification (3):

$$
\begin{aligned}
\frac{\Delta D_{i c t}}{E[Y]_{i c, 2001}}=\alpha & R_{i c, 2001}+\beta I_{c, 2001}+\gamma R_{i c, 2001} \times I_{c, 2001}+\psi X_{i c} \\
& +\phi D e b t_{i c, 2001}+\sigma D e b t_{i c, 2001} \times I_{c, 2001}+c^{+}+\epsilon_{i c t},
\end{aligned}
$$

Our baseline findings are unchanged with these additional controls (Panel B of Table 4).

We verify that our results do not hinge on the CCP measure of income inequality. We replicate our results from Table 3 in Appendix Table A1 using the measure of inequality constructed from IRS data and described in section 2.3 and find almost identical results. Finally, we also check that we are not mechanically inducing any spurious correlation between the interaction term and our outcome by using the imputed income on the left hand side and imputed rank in the interaction. To check this we estimate two additional specifications. The first replaces rank with the inverse of imputed income

$$
\frac{\Delta D_{i c t}}{E[Y]_{i c, 2001}}=\alpha \frac{1}{E[Y]_{i c, 2001}}+\beta I_{c, 2001}+\gamma \frac{1}{E[Y]_{i c, 2001}} \times I_{c, 2001}+\psi X_{i c}+\kappa W_{c}+c^{+}+\epsilon_{i c t} .
$$

By including the inverse of imputed income on the right hand side, we are inherently removing any first-order correlation between the outcome and variables on the right hand side. Thus, any higher-order correlation must be a feature of the data. The results of this estimation are found in Appendix Table A2 Panel A and show that with this specification we get qualitatively the same results since now the signs are reversed. In Appendix Table A2 Panel B we also estimate a specification where the outcome variable is the log difference of total debt keeping the baseline regressors and controls as in (4). We again find qualitatively similar results: low-income households saw their debt grow by less in high inequality areas than similar households in less unequal areas.

In short, the differential debt-accumulation patterns by households of differing income levels across inequality regions are a robust feature of the data.

\subsection{Subsample analysis}

Our finding that debt accumulation was higher for poorer households in low-inequality regions than highinequality regions is robust to controlling for a wide variety of household and regional observables. One may be concerned however that our interaction effect is capturing some other nonlinear characteristic of household borrowing, which need not be captured by linear controls. Alternatively, the income imputation could introduce spatial correlations due to omitted geographic differences. To address these possibilities, we consider an additional set of robustness checks in which we verify that our results still obtain within subsets of the data. Specifically, we break our regions along four dimensions: geographic areas, initial debt burdens, credit scores and house price growth. Note that in each of the subsample regressions we do not normalize inequality so that differences in magnitude are not necessarily the result of differences in economic effects.

For geographic areas, we estimate our specification with household and regional controls (equation (4)) separately for each of the four Census regions: Midwest, Northeast, South and West. We present the results of the 
household level regressions of debt accumulation from 2001 to 2007 (the main period over which household debt increased sharply) for each region in Panel A of Table 5, with the full set of yearly regressions by region available in Appendix Table A3. For each region, the coefficients are of the same sign as before and of approximately the same order of magnitude. Hence, our baseline results are confirmed within each region of the country.

Second, we decompose zip codes by the average level of credit scores among households in each locale in 2001. Specifically, we group zip codes into three bins: low credit scores (below the $33^{\text {rd }}$ percentile of average credit score distribution), medium (between the $33^{\text {rd }}$ and $67^{\text {th }}$ percentiles) and high credit scores (above the $67^{\text {th }}$ percentile of the average credit score distribution). We then rerun our specification with household and regional controls within each of these three credit score areas. The results for 2001-2007 are presented in Panel B of Table 5, with all yearly regressions by credit score grouping available in Appendix Table A4. Again, the results are qualitatively similar across credit score groups, although they are somewhat smaller in high credit score regions.

Third, we split zip codes according to median debt-to-income ratios in 2001. Specifically, we construct median initial debt-to-income ratios across all households in a zip code, then split zip codes into three groups based on these median ratios: low initial debt levels (below the $33^{\text {rd }}$ percentile of the debt-to-income distribution), medium (between the $33^{\text {rd }}$ and $67^{\text {th }}$ percentiles) and high debt-to-income ratios (above the $67^{\text {th }}$ percentile of the debt-to-income distribution). We then estimate our specification with household and regional controls within each of these three subsets of zip codes. We again present results for 2001-2007 in Panel C of Table 5, with the full set of yearly regressions by initial debt-to-income ratio available in Appendix Table A5. We find that our qualitative result holds across zip codes of different initial debt-to-income ratios but that the differential effects of inequality on household borrowing across income groups were largest in regions with higher initial debt-to-income ratios.

Fourth, we assess whether our results are sensitive to either the growth in house prices or the initial level of house prices relative to income. We measure house prices for each zip code using data from the Core Logic index. These data are only available for a subset of our zip codes (about 6,600) which constitutes about 70\% of our original sample. We split zip codes according either to their growth rates in house prices between 2001 and 2005 or according to their initial (2001) ratio of average house price to median income. In each case, we group zip codes into three bins: low (below the $33^{\text {rd }}$ percentile), medium (between the $33^{\text {rd }}$ and $67^{\text {th }}$ percentiles), and high (above the $67^{\text {th }}$ percentile). We re-estimate the specification with household and regional controls within each sub-grouping of zip codes and present results from 2001-2007 in Panels D (for house price growth) and E (for initial levels of house prices relative to income) of Table 5, with the full set of yearly regressions in Appendix Tables A6 and A7 respectively. The interaction of household rank and local inequality remains statistically significant within each subset of the data, with the results varying little depending on initial relative house price levels or subsequent house price appreciation. ${ }^{16}$

\footnotetext{
${ }^{16}$ Another way to characterize the insensitivity of our results to housing is to split the sample into households who had mortgage debt in 2001 vs. those who did not. As we document in Appendix Table A8, we find the same qualitative results for both groups: debt accumulation of low-income households was more pronounced in low-inequality regions than highinequality regions regardless of whether individuals already had a mortgage in 2001.
} 
Finally, we verify that our results are robust to the use of an alternative income imputation procedure which incorporates credit bureau attributes as independent variables in a model where actual and verified employer provided income is used to predict consumer income. Specifically, we utilize imputed income measures from the Equifax Credit Risk Servicing McDash (CRISM) dataset. Equifax constructs imputed income using detailed proprietary information about households' credit histories and mortgage information. The predicted relationship between income and other household information underlying their imputation comes from a large national sample of employer-provided known incomes to which Equifax applies a proprietary algorithm. This dataset is available starting in 2005. We reproduce all of our baseline results using this alternative measure of imputed income (results and more details about the data are in Appendix H) and find the same qualitative results: low-income households in high-inequality regions accumulated less debt than similar households in lower inequality regions.

\subsection{Results from a Nonparametric Specification}

The specification in equation (2) assumes a linear relationship between debt accumulation, income and rank and local inequality. In this section, we relax this assumption and estimate a nonparametric specification. Specifically, we first split the sample of households into three bins according to the level of local inequality. In particular, each location (zip code) is assigned to one of the three bins based on the location's level of inequality in the distribution of inequality across locations in 2001, i.e., low-inequality bin (less than the $20^{\text {th }}$ percentile of the distribution of local inequality levels), mid-level inequality bin (between the $20^{\text {th }}$ and $80^{\text {th }}$ percentile), and high-inequality bin (above the $80^{\text {th }}$ percentile). The assignment of locations to inequality bins remains constant through 2002-2012. We similarly group households into bins based on income ranks (below $20^{\text {th }}$ percentile, above $80^{\text {th }}$ percentile, and between $20^{\text {th }}$ and $80^{\text {th }}$ percentiles). We then run a regression of households' relative debt accumulation on dummies for each income rank category and inequality bin, with regional controls and the county-specific fixed effects for each year separately. The omitted category is the dummy for low-rank households in low-inequality regions.

Figure 7 shows the estimated coefficients for low- and high-rank households in each type of region. ${ }^{17}$ The differences across inequality regions for high-ranked households (i.e. those above the $80^{\text {th }}$ percentile) are small throughout the time sample. In contrast, low-ranked households display much larger differences in debt accumulation patterns across low- and high-inequality regions, with differences in debt accumulation reaching over 50 percent of initial income levels by 2008. Hence, the link between inequality and debt accumulation was relatively more important for low-income households than for high-income households.

\subsection{Results with County- and State-Level Income Distribution and Inequality Measures}

Previous work on inequality and consumption has used measures of inequality at the state level (see Bertrand and Morse, 2013) and most discussion of inequality and debt has focused on measures of inequality at the national level, as in Figure 1. We explore how our results vary as we increase the level of geographic aggregation for

${ }^{17}$ Results for mid-rank households are included in Appendix Figure 1. They display no meaningful differences across areas of high or low-inequality. 
inequality by estimating equation (4) using the income distribution at the county and state level. We construct the area income distribution using the same resampling procedure we used for zip codes and now we compute a household's percentile rank within the larger area (e.g. county) income distribution and inequality statistics of that distribution. We keep all household and regional-level controls that we used before except now we include state fixed effects for county-level regressions and no fixed effects for state-level regressions.

Panels A and B of Table 6 report the results with county- and state-level income distribution and inequality measures, respectively. At the county level, we find very similar results to our zip code regressions once we consider that the standard deviation of inequality is smaller at the county level. We also find very similar estimates of the interaction term when inequality is measured at the state level, although there is some loss of precision in our estimates due to the aggregation. These results indicate that the effects we measure at the zip-level are also apparent at higher levels of aggregation. Also noteworthy is that the estimate of $\beta$ is positive at the state level, implying that households on average accumulated relatively more debt in states with higher levels of inequality. This is similar to the result obtained by Bertrand and Morse (2013) that typical households consumed more in states where consumption of the rich was higher.

\subsection{Results by Form of Debt}

We now consider debt accumulation patterns along different dimensions of debt: mortgages, auto loans and credit cards. For each, we reproduce our household-level regressions with household and regional controls and county fixed effects and report yearly results in Table 7. Panel A documents that the results for mortgages are almost identical to those found for total debt. Because mortgage debt on average accounts for two-thirds of total debt, it is likely the primary driver of total debt patterns described above. Panel B documents that very similar qualitative results obtain for auto loans: both $\alpha$ and $\beta$ are estimated to be negative while the interaction term $\gamma$ is positive. However, the interaction effects are significantly smaller for auto loans than for mortgages, even if we adjust for the relative magnitudes of each form of debt (i.e. convert to growth rates). For example, the peak interaction effect on auto loans is about 0.05 , which when adjusted by the average ratio of auto debt to mortgage debt (mortgage debt is almost eight times as large as auto debt on average) becomes 0.4, one-third to one-fourth of the mortgage interaction effect. Though auto loans display the same qualitative patterns, the mapping from local inequality to differential borrowing patterns across households is quantitatively weaker than for mortgages.

Panels C and D report equivalent results for credit card balances and credit card limits. The distinction between credit card balances and limits is useful because the former can be expected to be very elastic with respect to the demand for credit while credit limits should be significantly less elastic with respect to household demand. ${ }^{18}$ Strikingly, we find very different results for the two measures. With credit card limits, we recover the same qualitative features as in our baseline estimates for total debt, $\alpha$ and $\beta$ are both estimated to be systematically

\footnotetext{
${ }^{18}$ This distinction is somewhat offset by the fact that households can endogenously raise their credit limits by applying for more credit cards or requesting higher limits from their current credit card providers.
} 
negative while the interaction term $\gamma$ is positive. With credit card limits being approximately half of mortgage debt on average, the estimated peak level of $\gamma$ of around 0.6 is approximately one-third as large as the peak interaction effect estimated for mortgages in terms of implied growth rates of each form of debt. In contrast, we find no consistent or economically significant relationship between local inequality and the credit card balances of households across different income groups: both $\beta$ and $\gamma$ are estimated to be very small (in some years becoming statistically insignificant) and the sign of $\gamma$ unstable across years. Thus, to the extent that we can interpret credit card balances and limits as reflecting credit demand and supply respectively, these results suggest that the differential borrowing patterns of lower- and higher-income households across regions of different inequality reflect differential credit supply conditions, not differential credit demand.

\section{Credit Prices and Access to Credit}

In the previous section we documented that inequality and debt accumulation are related and we provided suggestive evidence that supply-side forces might be the source of these relationships rather than demand-side mechanisms as previously emphasized. In this section, we consider and test three ways in which a differential supply of credit could manifest itself, focusing specifically on the supply of credit for mortgages. First, we look at the geographic locations of bank branches. Individuals with no ready access to bank branches face extra costs to acquiring mortgages, so areas with more branch locations provide readier access to credit for local households. The location of bank branches (e.g. relatively more branches in wealthy neighborhoods in higher inequality areas) can therefore serve as a way to make credit access easier to some subsets of a population within a geographic area. Second, we assess whether, once an individual has made it to a branch and applied for a mortgage, they are equally likely to get it across locations or whether their probability of approval varies depending on the local level of inequality. Finally, we focus on the interest rate on a mortgage received by a successful applicant, and the extent to which it varies with local inequality for a given applicant. We also argue that alternative demand-side explanations are inconsistent with these results. Intuitively, by observing the co-movement of credit prices and quantities, we will be able to determine if supply-side or demand-side factors are behind the role of inequality.

\subsection{Data and Framework}

Because CCP does not have information on interest rates or access to credit, we use information on mortgage applications from the publicly available Home Mortgage Disclosure Act database (HMDA), 2001-2012, to generate measures of credit prices. The HMDA data are compiled from reports filed by mortgage lenders. The HMDA was passed by Congress in 1975 and began requiring lenders to submit data reports in 1989. The initial intention of the act according to the Consumer Financial Protection Bureau (2012) was to monitor the provision of credit in urban neighborhoods to monitor discriminatory lending practices. The coverage is thought to be very extensive with Dell'Ariccia et al. (2012) reporting that HMDA covers between 77\% and 95\% of all mortgage originations from 2000 to 2006. Reporting criteria differ between depository and non-depository institutions and 
across years. ${ }^{19}$ Lenders who file reports include detailed information on every mortgage application received by the lender during a calendar year. All years of the data contain the size of the loan, income on the application, location of the property down to the census tract, demographics of the applicants, a lender identifier, and the action taken on the loan. Since 2004 the data include additional information including a censored picture of interest rates and the loan's lien status. We use a random sample of all HMDA records.

While the data are very detailed in many respects there are some limitations. First, the data do not identify “piggyback” loans, i.e. loans with subordinate liens used to finance a larger first-lien loan. These secondary loans can be used to lower financing costs and to avoid requirements that a loan being sold to Fannie Mae or Freddie Mac be accompanied by private mortgage insurance if a loan does not meet certain standards. The HMDA does not require lenders to report HELOCs and some piggyback loans might be issued by a lender not covered by HMDA, but some piggyback loans are almost certainly included in the dataset. Given that these loans are not identified, a researcher might infer a much lower loan-to-value ratio than the actual loan-to-value on the property. Since we are not able to identify piggyback loans reliably and these loans are relatively small, we drop all applications where the loan-toincome (LTI) ratio is less than one. In contrast to the CCP database, the HMDA data set does not track applicants over time and hence we do not have a panel of applicants/borrowers. To be consistent with the CCP analysis we report results measuring inequality at the county level.

We focus on three outcome variables that primarily measure supply-side choices. First, given that households have a stated and revealed preference for dealing with banks that are more accessible (CFPB 2015), we measure the distance between lenders and borrowers since lenders might choose to locate near neighborhoods with households they hope to serve. Second, we assess whether the probability of a loan being rejected depends on the applicant's income rank (within the pool of applicants) interacted with regional inequality. Third, we examine if the size of the loan relative to income varies with inequality. Finally, we consider whether the probability of the loan being "high-interest” (conditional on a loan application being approved) varies with inequality and the applicant's rank. ${ }^{20}$ All of these observables are arguably measures of some dimension of the price of credit.

To be consistent with our previous analyses, we use the following regression ${ }^{21}$

$$
\text { Outcome }_{i c t}=\alpha \text { Rank }_{i c t}+\gamma \text { Rank }_{i c t} * \text { Inequality }_{c, 2001}+\beta Z_{i c t}+\lambda_{c}+\text { error },
$$

\footnotetext{
${ }^{19}$ Depository institutions have typically been required to report if they satisfy an asset threshold, make at least one home mortgage, are federally regulated or insured, and have a branch in a metropolitan area. Non-depository institutions were required to report if the share of home mortgages exceeded a threshold of all loan originations, the lender operated in an MSA, and met an asset threshold. In 2004 the share threshold was supplemented with a level of home mortgage originations to increase the coverage of the market.

${ }^{20}$ The HMDA reporting guidelines require lenders to report the spread between the Treasury yield and the mortgage interest rate if the spread is greater than three percentage points for first-lien loans or five percentage points for subordinate-lien loan. ${ }^{21}$ Our baseline specification includes a county fixed effect because the county-level controls are not as detailed as those we can construct in the CCP data. Specifications with a state-level fixed effects and controlling for applicant income in addition to rank are available in Appendix Tables A10-12.
} 
where $\operatorname{Rank}_{i c t}$ is the percentile rank of applicant $i$ 's income within the pool of applicants in area $c$ in year $t .^{22}$ The inequality measure and the income distribution are defined at the county level. The explanatory variables in vector $Z_{i c t}$ include indicators for whether or not the loan is for an owner-occupied property, several race categories and gender, as well as the interaction of the applicant's income rank with the share of applicants in the county who are nonwhite. ${ }^{23}$ We also control for the loan-to-income ratio in the application. We restrict the analysis to loans for home purchases, applications where the loan-to-income ratio is at most eight and not less than one, loans where the reporter was directly making the origination decision (i.e. the loan was not purchased), and where the loan did not fail because of incompleteness or because it was not pre-approved. Notice that we retain in the sample loans that are not denied but also not originated. Excluding these does not change our results. As before, we are interested in the sign of the interaction term between income rank and inequality, $\gamma$. All standard errors are clustered at the county level. The regressions are estimated separately for each year, 2001-2012. We use the log of the 90/10 income ratio derived from the income imputed in the CCP data in 2001 as the measure of inequality, but the results are similar using the Gini coefficient from the Census data.

\subsection{Access to Credit}

We first consider how banks choose to locate their branches relative to potential borrowers. We estimate the distance between a borrower and a lender for the subset of borrowers taking out loans from lenders with branches recorded in the FDIC Summary of Deposits data within a 50 mile radius. ${ }^{24}$ This amounts to approximately $25 \%$ of all originated home purchase mortgages in the data. We miss all loans outside of 50 miles as well as loans to lenders without branches (e.g. thrifts without branches, online lenders). We measure the borrower's location as the centroid of the census tract recorded on the originated mortgage, which refers to the relevant property. The lender's location is taken as the nearest branch to that borrower's census tract. On average borrowers are almost eight miles away from their mortgage originator, but the distribution is heavily skewed with a median of three miles. The results are presented in Panel C of Table 8. The coefficient $\gamma$ is the parameter of interest and we consistently estimate it to be negative across all years, although the precision is relatively lower in 2004 and 2005. This estimate implies that as inequality increases high-rank households are nearer to their lender's branch while the distance between low-rank households and lenders is increasing. In response to a standard deviation increase in inequality the difference amounts to a $3 \%$ difference in distance between the $80^{\text {th }}$ and $20^{\text {th }}$ percentile borrowers. This estimate is consistent with lenders making credit more accessible to borrowers more likely to be of a high quality in more unequal areas.

To sharpen this result, we test if lenders are more responsive to neighborhood income when opening a new branch in counties with more inequality. Specifically, we identify where FDIC member institutions open new branches. We then rank census tracts within a county by median household income and estimate a logit model for whether or not

22 The results are also robust to measuring an applicant's rank in the distribution of income of all households in the county.

${ }^{23}$ We include this interaction as an additional control because previous studies have suggested that banks may treat differentially areas with predominantly non-white population. See Turner and Skidmore (1996) for a review.

${ }^{24}$ Available at https://www5.fdic.gov/sod/. To match bank branches to lender codes we rely on the file from Robert Avery. 
a census tract had a new branch open in a year (i.e., each observation is a census tract-year combination). As with our other specifications we include the rank of the census tract, our measure of the county's inequality, and the interaction of the two. Because branch openings are relatively infrequent and uneven across the sample (about 11\% of the observations have a branch opening) we pool the data across years. We also include controls for minority population, share of owner-occupied units, and the share of units that are single-family housing. Table 9 reports these estimates and shows that high-rank census tracts are more likely to have a branch open as inequality increases. This estimate is also quite robust across various levels of fixed effects. The implied difference in probability is economically significant: a standard deviation increase in inequality implies that a census tract ranked 0.8 is about five percentage points more likely to see a new branch open relative to a census tract ranked 0.2.

We then consider how banks treat individuals once they have submitted mortgage applications. The probability of an application being rejected by a bank is reported in Panel A of Table 8. The estimated $\gamma$ is consistently negative: applications from high-ranked households in high-inequality regions are less likely to be rejected than those from highranked households in low-inequality regions. This result suggests that banks use an applicant's position in the local income distribution, along with the dispersion of that distribution, to make inferences about default risk. Using our 2007 estimates, we find that a one standard deviation increase in inequality will decrease the probability of denial of a household in the $80^{\text {th }}$ percentile rank relative to the $20^{\text {th }}$ percentile rank by approximately 2 percentage points. This is comparable in magnitude to the association between rank and the probability of denial.

We also consider whether the size of the mortgage (intensive margin) varies across inequality regions and ranks within the income distribution by using the loan-to-income ratios associated with each originated mortgage. We use the same controls as with rejection probabilities (with the exception of LTI ratios) and county fixed effects. The results for each year are presented in Panel B of Table 8. Unlike mortgage rejection rates, we find little evidence that loan-to-income ratios vary across households in different inequality regions. To the extent that requested loans reflect demand for credit by households, we again find little evidence that demand-side factors related to local inequality levels mattered for the debt-accumulation decisions of households. However, the HMDA dataset does not allow us to establish if households have multiple loans or reliably link piggyback loans to standard loans.

\section{3. $\quad$ Price of Credit}

Results for the probability of a loan being high-interest, conditional on origination, are in Panel D of Table 8 (this variable is not available before 2004). Similar to the results for access to credit, high-rank applicants are less likely to face higher rate loans in high-inequality regions than in low-inequality regions. Doing the same calculation as above with the 2007 estimate, we find that high-rank households will see the probability that they pay a high interest loan decline by 1.5 percentage points relative to low-rank household.

These results tend to show that in addition to high-income households borrowing more as inequality increases, these same households are facing lower credit costs and better access to credit. The reverse is true for lowincome households. This conditional negative correlation between prices and quantities is strongly suggestive that 
inequality affects local credit markets through a supply-side mechanism. However, in the next section we also examine several plausible demand-side mechanisms that could potentially drive our results.

\subsection{Additional Tests of Credit Demand Mechanisms}

One potential demand-side explanation for our findings is that high- and low-income households' income expectations or growth vary systematically with inequality. If high-income households expect a relatively larger increase in permanent income growth in areas where inequality is high then we might expect them to borrow more.

While we do not have the income expectations data necessary to test this channel directly, we can test implications of this alternative explanation. One such implication is that if high-income households' incomes were growing faster relative to low-income households in more unequal areas, then we would expect to see divergence in income inequality across regions. Specifically, areas with higher initial levels of inequality should experience rising levels of inequality relative to other regions in subsequent years so that $\beta$ in the following cross-sectional regression should be greater than one

$$
\text { Inequality }_{i t+1}=\alpha+\beta_{t} \text { Inequality }_{i t}+e_{i} .
$$

We test this implication using data from the Integrated Public Use Microdata Series (IPUMS) on household incomes in metro areas. We restrict the sample to the set of metro areas identified consistently from 1970 to 2000, to households where the respondent's age is between 25 and 65, and where the respondent is the head of the household or the spouse of the head of the household. To calculate income we use total family income. This leaves us with a sample of 117 metro areas covering roughly $60 \%$ of the U.S. population. ${ }^{25}$ We measure inequality in each period as log of the p90/p10 ratio although results for other measures are similar. Table 10 provides the OLS coefficients from these regressions using base years of 1970, 1980, and 1990 and inequality levels for 2000 as the dependent variable. For all years the estimated coefficient is positive but significantly below one, suggesting that income distributions are stable on average. Estimates using quantile and robust regression give nearly identical results.

We also test if income growth by income decile varies with local inequality. For decile $j$ in area $i$, the average income is $\bar{Y}_{i j}$ so that we estimate

$$
\log \left(\bar{Y}_{i j t+1}\right)-\log \left(\bar{Y}_{i j t}\right)=\alpha+\beta_{j} \text { Inequality }_{i t}+e_{i}
$$

Figure 8 plots these coefficients along with 95\% confidence intervals measuring income growth from 1970 to 2000 and 1990 to 2000. While the bottom decile appears to be a strong outlier, the observed patterns do not suggest that high-income deciles experienced higher income growth in areas that were more unequal. In fact, the graphs appear to have a downward slope, which suggests a convergence in the income distributions across regions over time. This is consistent with the results in Table 10.

Neither of these exercises suggests that income growth for high-income households was relatively higher in high-inequality areas. Instead, we find that lower-income households living in high-inequality regions have tended

${ }^{25}$ See Appendix C for more details on the data. 
to experience relatively higher income growth, leading to convergent dynamics in regional inequality over time. These results suggest that differential income growth is not likely to be driving our results.

Another potential demand-side mechanism that could explain our findings is if households try to segregate themselves more when local inequality levels are higher. For example, as high-income households become increasingly richer than low-income households, then high-income individuals may have a greater desire to live with other high-income individuals. One immediate limitation of this story is that it only has implications for mortgage debt while Table 7 documents the qualitative consistency of our results across auto debt and credit card limits. Additionally, in Appendix Table A9, we introduce the interaction of several local observables likely to be correlated with the motivation for economic segregation. We separately interact rank with the share of homeowners, the share of nonwhite residents, the county-level crime rate (computed from the Uniform Crime Reporting Statistics), and the dispersion of housing quality (measured as the log ratio of average house prices at the top and bottom third from Zillow). Our results for the interaction of rank and local inequality are essentially unchanged even though a number of these additional interactions are economically and statistically significant.

\section{Model}

In this section, we present a stylized model to illustrate how our empirical findings can be rationalized via credit supply mechanism. In this model, lenders use local inequality to extract information about applicant types in order to differentiate between borrowers of varying credit quality. Intuitively, as inequality increases it becomes easier for the lender to tell applicants of different quality apart and so price credit more efficiently, which results in borrowing patterns similar to those we find in the CCP and HMDA data. We demonstrate these results under two types of market structure: perfect competition and monopoly.

Suppose there are two types of households: High $(H)$ and Low $(L)$. To simplify algebra, we assume that High type households never default on debt while Low type households default with probability $d$ and that the share of High type households is $0.5 .{ }^{26}$ The income for an individual $i$ of type $j \in\{H, L\}$ is given by $y_{i, j}=\mu_{j}+e_{i}$ where $\mu_{H}>\mu_{L}$ are constants and $e_{i} \sim N\left(0, \sigma^{2}\right)$. Hence, $y_{H} \sim N\left(\mu_{H}, \sigma^{2}\right)$ and $y_{L} \sim N\left(\mu_{L}, \sigma^{2}\right)$. Denote the pdfs for each distribution with $\phi_{H}$ and $\phi_{L}$. The average income in this economy is $\bar{y}=\frac{1}{2} \mu_{H}+\frac{1}{2} \mu_{L}$.

We also assume banks observe $s$, another signal about the quality of borrowers that can incorporate other information about borrowers and is not observed by the econometrician, to capture the idea that loan officers have more information than econometricians. Similar to the income signal, $s_{i, j}=\rho_{j}+\eta_{i}$ where $\rho_{H}>\rho_{L}$ are constants and $\eta_{i} \sim$ iid $N\left(0, \omega^{2}\right)$. Denote the pdfs for each distribution with $q_{H}$ and $q_{L}$. To simplify algebra, we assume without loss of generality that idiosyncratic shocks to income and signal $s$ are independent.

\footnotetext{
${ }^{26}$ We document in Appendix F that high-income households are indeed less likely to default than low-income households.
} 
Banks do not observe household types directly but they observe applicants' incomes and signal $s .{ }^{27}$ They can then infer the probability of a given type conditional on observed income. Specifically, using Bayes’ theorem, the posterior probability of being High type for a household $i$ with signals $y_{i}$ and $s_{i}$ is given by

$$
\begin{aligned}
\operatorname{Pr}\left(H \mid y_{i}, s_{i}\right) & =\frac{\operatorname{Pr}\left(y_{i} \mid H\right) \operatorname{Pr}\left(s_{i} \mid H\right) \operatorname{Pr}(H)}{\operatorname{Pr}\left(y_{i} \mid H\right) \operatorname{Pr}\left(s_{i} \mid H\right) \operatorname{Pr}(H)+\operatorname{Pr}\left(y_{i} \mid L\right) \operatorname{Pr}\left(s_{i} \mid L\right) \operatorname{Pr}(L)} \\
& =\frac{\phi_{H}\left(y_{i}\right) q_{H}\left(y_{i}\right) \frac{1}{2}}{\phi_{H}\left(y_{i}\right) q_{H}\left(y_{i}\right) \frac{1}{2}+\phi_{L}\left(y_{i}\right) q_{L}\left(y_{i}\right) \frac{1}{2}}=\frac{\Phi\left(y_{i}\right) Q\left(s_{i}\right)}{\Phi\left(y_{i}\right) Q\left(s_{i}\right)+1}
\end{aligned}
$$

where $\Phi\left(y_{i}\right) \equiv \phi_{H}\left(y_{i}\right) / \phi_{L}\left(y_{i}\right)$ and $Q\left(s_{i}\right) \equiv q_{H}\left(s_{i}\right) / q_{L}\left(s_{i}\right)$ are the likelihood ratios. Given our assumptions, we have $\Phi^{\prime}>0$ and $Q^{\prime}>0$, that is, High type households are monotonically more likely to be observed as income $y$ or signal $s$ increase. Since there are only two types, it follows that

$$
\operatorname{Pr}\left(L \mid y_{i}, s_{i}\right)=1-\operatorname{Pr}\left(H \mid y_{i}, s_{i}\right)=\frac{1}{\Phi\left(y_{i}\right) Q\left(s_{i}\right)+1} .
$$

Clearly, $\frac{\partial \operatorname{Pr}\left(L \mid y_{i}, s_{i}\right)}{\partial y_{i}}<0, \frac{\partial \operatorname{Pr}\left(L \mid y_{i}, s_{i}\right)}{\partial s_{i}}<0, \frac{\partial \operatorname{Pr}\left(H \mid y_{i}, s_{i}\right)}{\partial s_{i}}>0$, and $\frac{\partial \operatorname{Pr}\left(H \mid y_{i}, s_{i}\right)}{\partial y_{i}}>0$.

Banks potentially have two margins to determine which borrowers obtain loans: 1) price of loans; 2) loan denial probability. While in reality banks are likely to use both margins, we consider polar cases to illustrate the workings of each margin separately. For the price margin, we will assume that banks can price discriminate borrowers perfectly, banks compete in all population segments, and banks can freely obtain resources at rate $R_{0}$ (“perfect competition”). For the loan denial probability, we assume that there is only one bank serving the market but this bank is threatened by entry of other banks if this bank makes a profit (“monopoly”).

\subsection{Perfect Competition}

With perfect competition and free entry in each lending segment, banks can have only one interest rate for a borrower of a given quality. Since there is a continuum of borrower quality, there is also a continuum of markets where each market is indexed by borrower quality. Consider a set of households with income $y_{i}$ and signal $s_{i}$. Given by the zero profit condition, the interest rate is set to

$$
\begin{gathered}
R^{*}\left\{(1-d) \operatorname{Pr}\left(L \mid y_{i}, s_{i}\right)+\operatorname{Pr}\left(H \mid y_{i}, s_{i}\right)\right\}=R_{0} \Rightarrow \\
R^{*}=\frac{R_{0}}{(1-d) \operatorname{Pr}\left(L \mid y_{i}, s_{i}\right)+\operatorname{Pr}\left(H \mid y_{i}, s_{i}\right)}=R_{0} \frac{\Phi\left(y_{i}\right) Q\left(s_{i}\right)+1}{\Phi\left(y_{i}\right) Q\left(s_{i}\right)+(1-d)}=R^{*}\left(y_{i}, s_{i}\right)
\end{gathered}
$$

Note that households with other levels of $y$ and $s$ pay the same interest rate as long as $\Phi\left(y_{i}\right) Q\left(s_{i}\right)=\Phi(y) Q(s)$. That is, each lending segment is characterized by a pair of signals

$$
\mathcal{S}\left(R^{*}\right)=\left\{(y, s): R_{0} \frac{\Phi(y) Q(s)+1}{\Phi(y) Q(s)+(1-d)}=R^{*}\right\} .
$$

\footnotetext{
${ }^{27}$ Obviously, banks observe many other characteristics of households. We abstract from this additional information available to banks to simplify derivations. One may interpret this approach as partialling out these other characteristics. Typically, one of the important indicators of individual's risk is individual's credit score. In the analysis in section 3, we show that the household's income rank has explanatory power for the household's debt even after we control for the credit score.
} 
where $R^{*}$ is a sufficient statistic for the quality of borrowers. Because the quality of borrowers is the same in $\mathcal{S}\left(R^{*}\right)$, every borrower in $\mathcal{S}\left(R^{*}\right)$ obtains a loan at the interest rate $R^{*}$. Borrowers of a worse quality are offered loans at higher interest rates while borrowers of better quality can obtain a loan with a lower interest rate.

Clearly, $\frac{\partial R^{*}}{\partial y}<0$ and $\frac{\partial R^{*}}{\partial s}<0$ so that households with high income $y$ and strong signal $s$ pay lower rates because banks believe that these applicants are more likely to be of the High type. To see the tradeoff between $y$ and $s$, one can fix $R^{*}(y, s)$ at level $R^{\#}$ and find the required signal $s$ to allow a household to borrow at rate $R^{\#}$ given that this household has income $y$ :

$$
S^{*}(y)=Q^{-1}\left\{\frac{1}{\Phi(y)} \times \frac{R_{0}-R^{\#}(1-d)}{R^{\#}-R_{0}}\right\}
$$

where $Q^{-1}$ is the inverse function of $Q$. Given that $Q^{\prime}>0$ and $\Phi^{\prime}>0$, it follows that $\frac{\partial s^{*}(y)}{\partial y}<0$.

Although we (unlike loan officers) do not observe signal $s$ in the data, we can still calculate the interest rate paid on average by households with income $y$, which is observed by the econometrician:

$$
R^{*}(y)=\int R^{*}(y, s)\left\{q_{H}(s) \frac{1}{2}+q_{L}(s) \frac{1}{2}\right\} d s
$$

Given that $R^{*}(y, s)$ is differentiable and otherwise well behaved as well as $\frac{\partial R^{*}(y, s)}{\partial y}<0$, we have that

$$
\frac{\partial R^{*}(y)}{\partial y}=\int \frac{\partial R^{*}(y, s)}{\partial y}\left\{q_{H}(s) \frac{1}{2}+q_{L}(s) \frac{1}{2}\right\} d s<0 .
$$

Hence, the model predicts that the interest rate decreases in household income.

One can then consider a thought experiment of raising the income inequality in this economy without changing the mean level of income. Specifically, we increase the distance between $\mu_{H}$ and $\mu_{L}$ but the average income $\bar{y}$ is held constant. ${ }^{28}$ Because income levels are now a stronger signal of an applicant's type, banks put a higher weight on signal $y$, hence the slope of the tradeoff becomes steeper as it takes a larger change in signal $s$ to justify lending at a given interest rate (see Panel A of Figure 9). This will lead to higher borrowing on the part of low-income households in low-inequality regions than in high-inequality regions because, in the former, banks are less sure about the underlying type of the applicant based on income and therefore are more willing to lend to households of different incomes. In other words, $R_{\text {equal }}^{*}(y)<R_{\text {unequal }}^{*}(y)$ when $y<\bar{y}$ where “equal” and “unequal” denote the level of inequality, captured by mean-preserving changes in $\mu_{H}$ and $\mu_{L}$, and $R_{\text {equal }}^{*}(y)>$ $R_{\text {unequal }}^{*}(y)$ when $y>\bar{y}$. Panel B of Figure 9 illustrates this point. In short, banks charge lower interest rates to

\footnotetext{
${ }^{28}$ Notice that increasing inequality in this manner is not innocuous. If we assumed instead that the variance of income increased, we would generate the opposite dynamic as income would now be a less precise signal of type. Modeling the increase in inequality as an increase in the distance between types of incomes is consistent with the nature of the increase in U.S. inequality. Debaker et al. (2013) decompose the increase in income inequality into permanent and transitory components and find the vast majority of the increase in inequality is due to dispersion in the permanent component of income. We view the spread in mean income between types as analogous to an increased dispersion in the permanent component of income.
} 
high-income households than to low-income households and the difference in the interest rates across income groups rises as the difference between these groups widens. ${ }^{29}$

We also study the effects of an increase in the supply of credit. Since perfect competition prices each borrower type fairly, we can only increase the supply of credit by reducing the cost of funds rate $R_{0}$. Equation (9) shows that a decrease in $R_{0}$ shifts schedule $s^{*}(y)$ down and hence all borrowers enjoy a lower cost of credit.

A combination of a positive credit supply shock ( $R_{0}$ decreases) and an increase in inequality $\left(\mu_{H}-\mu_{L}\right.$ increases) can reconcile how all types of households increased their borrowing on average over the course of the mid 2000s with the cross-sectional variation in debt-accumulation patterns across income groups at different levels of local inequality documented in section 3 . The supply shock by itself can explain the former while the increased inequality by itself can explain only the latter.

\subsection{Monopoly}

In practice, regulatory or informational constraints limit the ability of banks to charge different prices to different borrowers and therefore they often can charge only one rate or a limited number of rates for a given type of loan. To keep exposition simple, suppose that i) the market has only one bank and it is threatened by entry of other banks, ii) regulators impose a minimum quality of borrowers who may obtain loans (e.g., to qualify for Freddie Mac and Fannie Mae guarantees), and iii) the bank can charge only one rate $\bar{R}$.

To model assumption ii), we know that $R^{*}(y, s)$ can be used as a sufficient statistic for the quality of a borrower. The bank makes a profit on borrowers with $(y, s)$ such that $R^{*}(y, s)<\bar{R}$ and losses on borrowers with $(y, s)$ such that $R^{*}(y, s)>\bar{R}$. We will denote the cutoff interest rate $R^{+}$that meets the regulation requirements. With this cutoff rate, the threat of entry sets $\bar{R}$ at the level that yields zero profits as implied by assumption i).

$$
\bar{R} \frac{\iint_{(y, s): R^{*}(y, s) \leq R^{+}}\{(1-d) \operatorname{Pr}(L \mid y, s)+\operatorname{Pr}(H \mid y, s)\} \bar{\phi}(y) \bar{q}(s) d y d s}{\iint_{(y, s): R^{*}(y, s) \leq R^{+}} \bar{\phi}(y) \bar{q}(s) d y d s}=R_{0}
$$

where $\bar{\phi}(y) \equiv \frac{1}{2} \phi_{L}(y)+\frac{1}{2} \phi_{H}(y)$ and $\bar{q}(s) \equiv \frac{1}{2} q_{L}(s)+\frac{1}{2} q_{H}(s)$. Using the insight of equation (9), we can find the threshold level of signal $s$ such that a bank will lend to a household with income $y$ :

$$
S^{+}(y)=Q^{-1}\left\{\frac{1}{\Phi(y)} \times \frac{R_{0}-R^{+}(1-d)}{R^{+}-R_{0}}\right\}
$$

As before, we have $\frac{\partial s^{+}(y)}{\partial y}<0$. The set of households who obtain a loan is:

$$
\mathcal{S}^{+}\left(R^{+}\right)=\left\{(y, s): R_{0} \frac{\Phi(y) Q(s)+1}{\Phi(y) Q(s)+(1-d)} \geq R^{+}\right\}
$$

The probability that a household with income $y$ is denied a loan is

\footnotetext{
${ }^{29}$ Note that the value at which a household does not experience a change in the interest rate is equal to the average income $\bar{y}$. This value is insensitive to the level of inequality because by construction the average income is held constant and at the average income the likelihood ratios are equal to 1 and therefore the posterior probability is equal to $1 / 2$. This value, however, can move in more complex models and alternative parameterizations.
} 


$$
\operatorname{Pr}(\text { denied loan } \mid y)=\operatorname{Pr}\left(s<s^{+}(y)\right)=\int_{-\infty}^{s^{+}(y)} \bar{q}(s) d s
$$

Since $\frac{\partial s^{+}(y)}{\partial y}<0$, it follows that $\frac{\partial \operatorname{Pr}(\text { denied loan } \mid y)}{\partial y}<0$ : the probability of loan denial decreases in income.

Now we repeat the thought experiment with rising inequality. Similar to the perfect competition case, it takes a larger increment in signal $s$ to compensate for a given decrease in income $y$ because income is a more informative signal. As a result, if the quality of lending standard $R^{+}$is held constant, some low-income households may be denied a loan more often (see Panel C of Figure 9). Panel D of Figure 9 shows how the denial probability changes with rising inequality. The probability of denial increases for households with $y<\bar{y}$ and decreases for households with $y>\bar{y}$.

In contrast to the perfect competition case, the monopoly case has two ways to model an increase in the supply of credit. First, one can continue to model it as a reduction in the cost of funds rate $R_{0}$. Second, one can model it as an increase in $R^{+}$, i.e., relaxing lending standards to cover high-risk borrowers. In the first case, a decrease in $R_{0}$ lowers $\bar{R}$ and thus makes credit cheaper for households with $R^{*} \leq R^{+}$. However, it does not affect the interest rate for households with $R^{*}>R^{+}$as these continue to receive no loans (they do not meet lending requirements). In the second case, an increase in $R^{+}$raises $\bar{R}$ because a wider coverage now includes high risk households and losses made on these high-risk households have to be compensated by larger profit margins on low-risk households. Thus, while credit is now available to a broader spectrum of households, the cost of borrowing increases for relatively high-income borrowers. On the other hand, the probability of obtaining a loan increases for all households as schedule $s^{+}(y)$ shifts down. Hence, although high-income households pay a higher price for credit, they are denied loans less frequently.

Thus, our model can qualitatively account for why lower-income households accumulated relatively less debt in high-inequality regions than did similar households in low-inequality regions during the 2000s: if banks in higher-inequality regions placed more weight on applicants' incomes as a signal of their underlying creditworthiness and therefore channeled more funds toward higher-income applicants than did banks in lowerinequality regions. Under perfect competition, this differential access to funds is predicted to happen through higher interest rates being offered to low-income applicants than high-income applicants whereas under monopoly banking, our model predicts that banks will reject low-income applicants more frequently than high-income applicants. Because banking in the U.S. lies in between these two extremes, we can replicate both margins that were apparent in the data.

\section{Conclusion}

Using household level measures of debt over the course of 2001 - 2012, we document a systematic link between local levels of income inequality and the debt-accumulation decisions of households of different income levels. Specifically, we find that low-income households in low-inequality regions accumulated more debt during the mid-2000s than did low-income households in high-inequality regions, with reverse (albeit smaller) effects 
operating for high-income households. While these results point to an economic channel linking economic inequality and borrowing by households of different income groups, they are inconsistent with a prevailing view that low income households accumulate more debt when faced with higher inequality. Our results suggest that supply effects substantially curb such demand mechanisms. Instead, we document that lower-income mortgage applicants in high-inequality regions are rejected more frequently and pay higher interest rates than similar applicants in low-inequality regions. Similarly, lenders are more likely to open a new branch in a high-income neighborhood and high-income borrowers tend to be closer to lenders when inequality is higher. While it is possible that income inequality implicitly captures other factors that are not included in the data, our extensive robustness checks and the negative co-movements between prices and quantities suggest that the causality between inequality and debt is running through the credit supply channel.

Accordingly, we develop a simple lending model where income inequality matters for the information content of income when evaluating a borrower's credit risk. In the model, this channel leads to relatively more credit being allocated to low-income applicants when local inequality is low rather than high, since higher levels of inequality imply that applicant incomes are stronger signals of credit-worthiness. As a result, high-income borrowers are able to borrow at lower rates or more easily as inequality increases.

Our results suggest that a continuation of recent trends toward rising inequality might reduce access to credit for lower-income households. As it becomes easier for lenders to differentiate between high- and lowquality borrowers the credit allocation potentially becomes more efficient, but this can also have negative effects that we do not explicitly model. Because limited access to credit restricts households' ability to smooth their consumption and to engage in long-term investments (e.g. sending children to college, retraining for different careers), such differential access to credit could ultimately have negative longer term consequences. To the extent that many of these activities likely have positive societal externalities not captured in our model, such a development could have important policy implications.

\section{References}

Adelino, Manuel, Antoinette Schoar, and Felipe Severino. 2016. "Loan Originations and Defaults in the Mortgage Crisis: The Role of the Middle Class,” Review of Financial Studies, Vol. 29 (7): 1635-1670.

Agarwal, Sumit, Souphala Chomsisengphet, Neale Mahoney, and Johannes Stroebel. 2016. "Do Banks Pass Through Credit Expansions to Consumers Who Want to Borrow?,” NYU, mimeo.

Aguiar, Mark, and Mark Bils. 2015. "Has Consumption Inequality Mirrored Income Inequality?" American Economic Review 105(9), 2725-56.

Bertrand, Marianne, and Adair Morse. 2013. “Trickle-Down Consumption,” NBER WP No. 18883.

Blundell, Richard, Luigi Pistaferri, and Ian Preston. 2008. "Consumption Inequality and Partial Insurance," American Economic Review 98(5), 1887-1921.

Bordo, Michael D. andChristopher M. Meissner, 2012. “Does Inequality Lead to a Financial Crisis?” Journal of International Money and Finance 31(8), 2147-2161.

Brown, Meta, Andrew Haughwout, Donghoon Lee, and Wilbert van der Klaauw. 2011. "Do We Know What We Owe? A Comparison of Borrower- and Lender-Reported Consumer Debt.” N.Y. Fed Report no. 523.

Charles, Kerwin K., Erik Hurst, and Nikolai Roussanov, 2009. “Conspicuous Consumption and Race,” Quarterly Journal of Economics 124(2), 425-467. 
Christen, Markus and Ruskin M. Morgan, 2005. "Keeping Up with the Joneses: Analyzing the Effect of Income Inequality on Consumer Borrowing,” Quantitative Marketing and Economics 3, 145-173.

Consumer Financial Protection Bureau. 2012. Supervision and Examination Manual. Available at http://files.consumerfinance.gov/f/201210_cfpb_supervision-and-examination-manual-v2.pdf.

Consumer Financial Protection Bureau. 2015. Consumer's Mortgage Shopping Experience. Available at http://files.consumerfinance.gov/f/201501_cfpb_consumers-mortgage-shopping-experience.pdf.

Daly, Mary C. and Daniel J. Wilson, 2006. "Keeping Up with the Joneses and Staying Ahead of the Smiths: Evidence from Suicide Data,” Federal Reserve Bank of San Francisco WP 2006-12.

Debaker, Jason, Brad Heim, Vasia Panousi, Shanthi Ramnath, and Ivan Vidangos. 2013. "Rising Inequality: Transitory or Persistent? New Evidence from a Panel of US Tax Returns,” Brookings Papers on Economic Activity, Spring.

Dell’Ariccia, Giovanni, Deniz Igan, and Luc Laeven. 2012. “Credit Booms and Lending Standards: Evidence from the Subprime Mortgage Market,” Journal of Money, Credit and Banking, Vol. 44 (2-3), 367-384.

Demyanyk, Yuliya, and Otto Van Hemert. 2011. "Understanding the Subprime Mortgage Crisis," Review of Financial Studies, Vol. 24 (6): 1848-1880.

Elul, Ronel, Nicholas S. Souleles, Souphala Chomsisengphet, Dennis Glennon, and Robert Hunt, 2010. "What “Triggers” Mortgage Default?” American Economic Review Papers and Proceedings 100(2), 490-494.

Fay, Scott, Erik Hurst, and Michelle J. White, 2002. “The Household Bankruptcy Decision,” American Economic Review 92(3), 706-718.

Frank, Robert H., Adam Seth Levine, and Oege Dijk. 2014. "Expenditure Cascades", Review of Behavioral Economics, Vol. 1(1-2): 55-73.

Gropp, Reint, John Krainer, and Elizabeth Laderman. 2014. Did Consumers Want Less Debt? Consumer Credit Demand Versus Supply in the Wake of the 2008-2009 Financial Crisis, Federal Reserve Bank of San Francisco WP Np. 2014-08.

Gross, David B., and Nicholas S. Souleles, 2002. "An Empirical Analysis of Personal Bankruptcy and Delinquency,” Review of Financial Studies 15(1), 319-347.

Guerrieri, Veronica, Daniel Hartley, and Erik Hurst, 2013. "Endogenous Gentrification and Housing Price Dynamics,” Journal of Public Economics 100, 45-60.

Guven, Cahit, and Bent E. Sørensen, 2012. "Subjective Well-Being: Keeping Up with the Joneses. Real or Perceived?” Social Indicators Research 109(3), 439-469.

Heffetz, Ori, 2011. "A Test of Conspicuous Consumption: Visibility and Income Elasticities," Review of Economics and Statistics 93(4), 1101-1117.

Kennickell, Arthur B., 1998, “Multiple Imputation in the Survey of Consumer Finances,” Working paper, Federal Reserve Board, available at: http://www.federalreserve.gov/pubs/oss/oss2/method.html.

Keys, Benjamin J, Tanmoy Mukherjee, Amit Seru, and Vikrant Vig. 2010. "Did securitization lead to lax screening? Evidence from subprime loans,” Quarterly Journal of Economics, Vol. 125(1): 307-362.

Kuhn, Peter, Peter Kooreman, Adriaan R. Soetevent, and Arie Kapteyn, 2011. "The Effects of Lottery Prizes on Winners and their Neighbors: Evidence from the Dutch Postcode Lottery,” American Economic Review 101(5), 2226-2247.

Kumhof, Michael, Romain Rancière, and Pablo Winant. 2015. "Inequality, Leverage, and Crises." American Economic Review, 105(3): 1217-45.

Lee, Donghoon, and Wilbert van der Klaauw. 2010. “An Introduction to the FRBNY Consumer Credit Panel.” Federal Reserve Bank of New York, Staff Report no. 4799.

Luttmer, Erzo F. P., 2005. “Neighbors as Negatives: Relative Earnings and Well-Being,” Quarterly Journal of Economics 120(3), 963-1002.

Maurer, Jürgen, and André Meier, 2008. "Smooth It Like the Joneses? Estimating Peer-Group Effects in Intertemporal Consumption Choice,” The Economic Journal 118(527), 454-476.

Munnell, Alicia H., Geoffrey M. B. Tootell, Lynn E. Browne, and James McEneaney, 1996. "Mortgage Lending in Boston: Interpreting HMDA Data,” American Economic Review 86(1), 25-53.

Mian, Atif, and Amir Sufi. 2009. The Consequences of Mortgage Credit Expansion: Evidence from the U.S. Mortgage Default Crisis,” Quarterly Journal of Economics, Vol. 124(4):1449-1496. 
Mian, Atif, and Amir Sufi. 2014. House of debt: How they (and you) caused the Great Recession, and how we can prevent it from happening again. University of Chicago Press.

Neumark, David, and Andrew Postlewaite, 1998. "Relative Income Concerns and the Rise in Married Women’s Employment,” Journal of Public Economics 70(1), 157-183.

Perugini, Cristiano, Jens Holscher, and Simon Collie, 2013. "Inequality, Credit Expansion and Financial Crises,” Munich Personal RePec Archive Paper 51336.

Rajan, Raghuram G., 2010. Fault Lines: How Hidden Fault Lines Still Threaten the World Economy, Princeton University Press, Princeton N.J.

Stiglitz, Joseph . 2009. "Inequality and Economic Growth," Columbia University, mimeo. Accessed at: http://www8.gsb.columbia.edu/faculty/jstiglitz/sites/jstiglitz/files/Inequality\%20and\%20Economic\%20 Growth.pdf

Tootell, Geoffrey M. B., 1996. "Redlining in Boston: Do Mortgage Lenders Discriminate against Neighborhoods?” Quarterly Journal of Economics 111(4), 1049-1079.

Turner, Margery Austin, and Felicity Skidmore, 1999. Mortgage Lending Discrimination: A Review of Existing Evidence. The Urban Institute, Washington D.C.

Veblen, Thorstein. 1899. The Theory of the Leisure Class: An Economic Study in the Evolution of Institutions. Macmillan, 400 pp.

Zizzo, Daniel J. and Andrew J. Oswald, 2001. “Are People Willing to Pay to Reduce Others’ Income,” Annales d'Economie et de Statistique 63/64 39-65. 
FIGURE 1: INEQUALITY AND DEBT IN THE U.S.

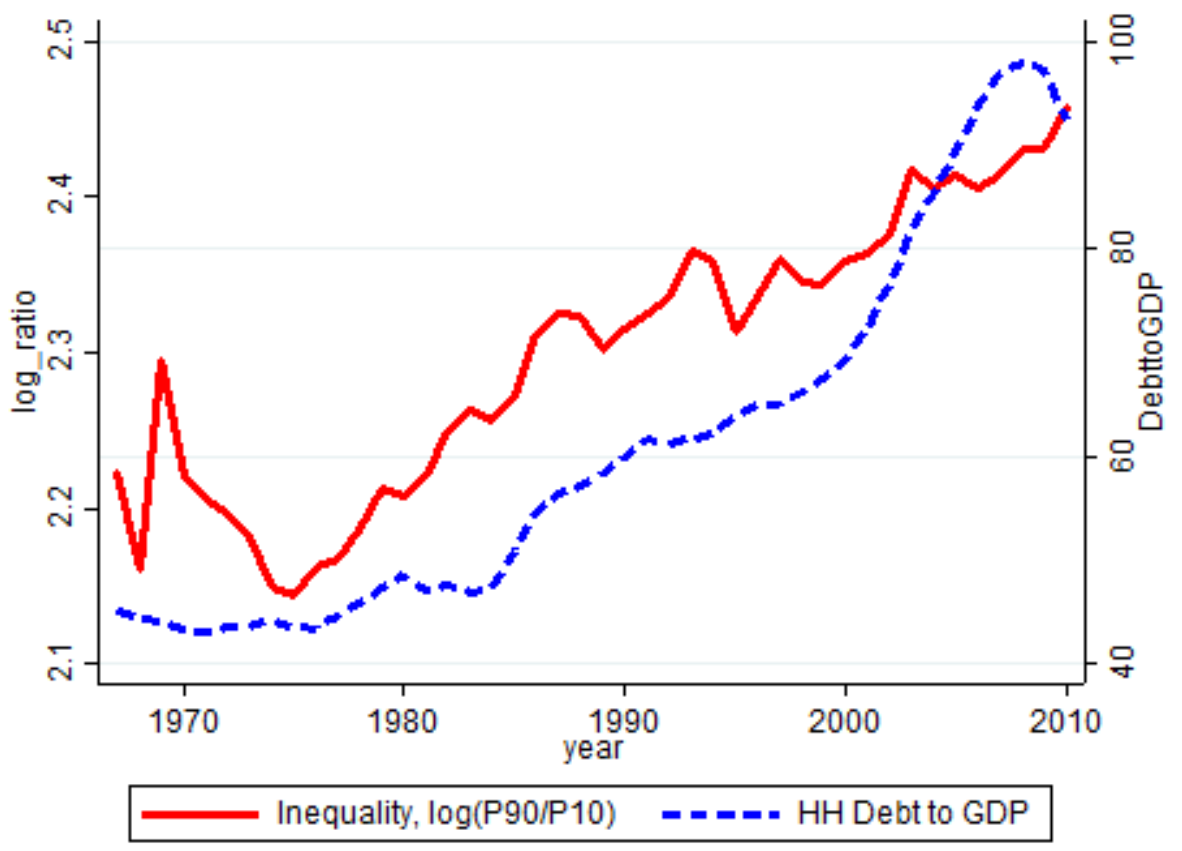

Note: The figure plots the $(\log )$ ratio of the $90^{\text {th }}$ percentile to the $10^{\text {th }}$ percentile of incomes of U.S. households (source: U.S. Census Bureau) and the ratio of household (and non-profit) total liabilities relative to GDP (source: Federal Reserve).

Figure 2: ACTUAL AND IMPUTED COUNTY LOG MEDIAN INCOME

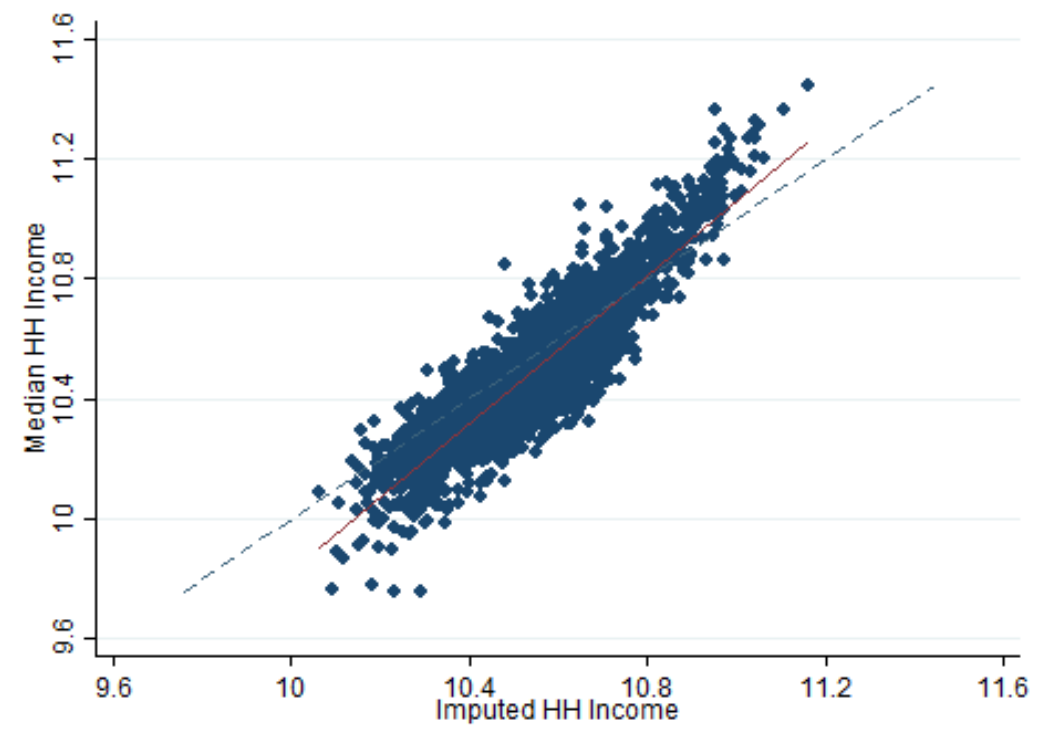

Note: The figure plots the log of median household income for each county against the median log household income from our imputation. The solid red line is the linear fit and the dotted blue line is the 45 degree line (source: Census SAIPE and authors' calculations). 
FIGURE 3: INEQUALITY ACROSS U.S. COUNTIES

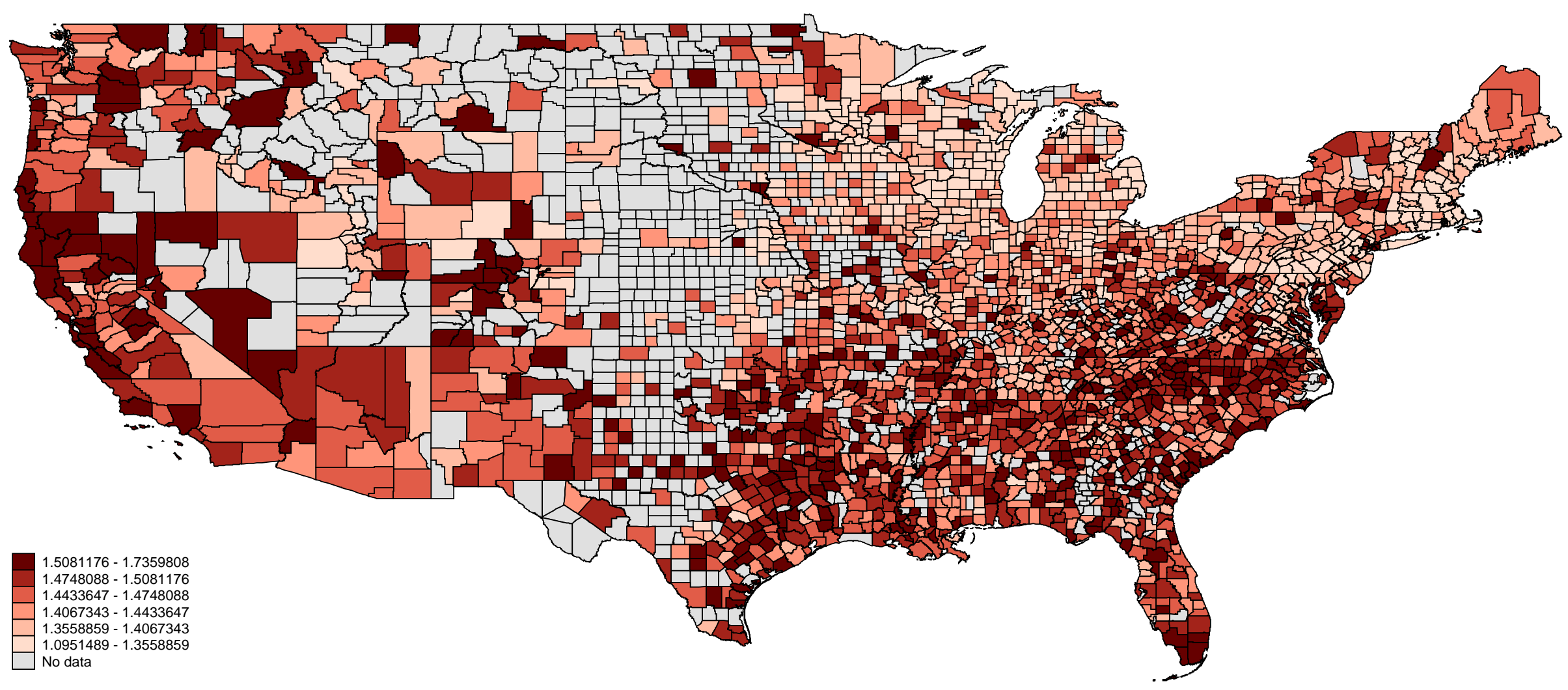

Note: The figure plots inequality in 2001 at the county level. Inequality is measured as the difference in log expected incomes at the $90^{\text {th }}$ and $10^{\text {th }}$ percentiles computed from the CCP. Darker counties are more unequal with each bin representing a quintile of the distribution across counties. 
FIGURE 4: CROSS-SECTIONAL INEQUALITY IN THE U.S.
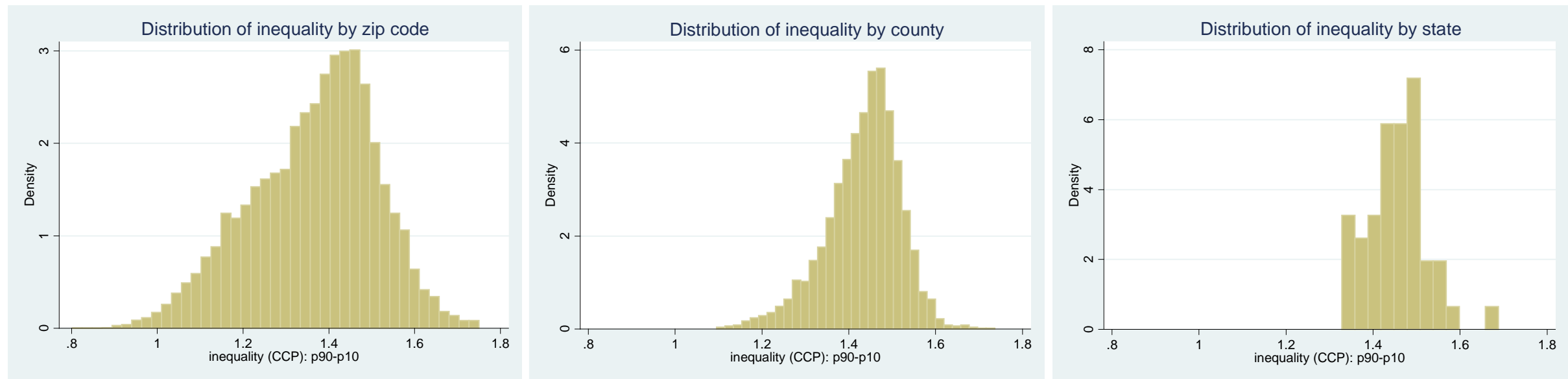

Note: The figures plot the regional distribution of inequality, measured using differences in expected log income between the $90^{\text {th }}$ and $10^{\text {th }}$ percentiles as computed from the CCP, at three levels of aggregation: zip code, county, and state level.

FIgURE 5: DEBT ACCUMUlATION, INCOME RANK AND LOCAL INEQUALITY
A) $\boldsymbol{\alpha}<\mathbf{0}, \boldsymbol{\beta}=\mathbf{0}, \boldsymbol{\gamma}=\mathbf{0}$
B) $\boldsymbol{\alpha}<\mathbf{0}, \boldsymbol{\beta}>\mathbf{0}, \boldsymbol{\gamma}<\mathbf{0}$

C) $\boldsymbol{\alpha}<\mathbf{0}, \boldsymbol{\beta}<\mathbf{0}, \gamma>\mathbf{0},|\gamma|>|\boldsymbol{\beta}|$

$\Delta D / Y$

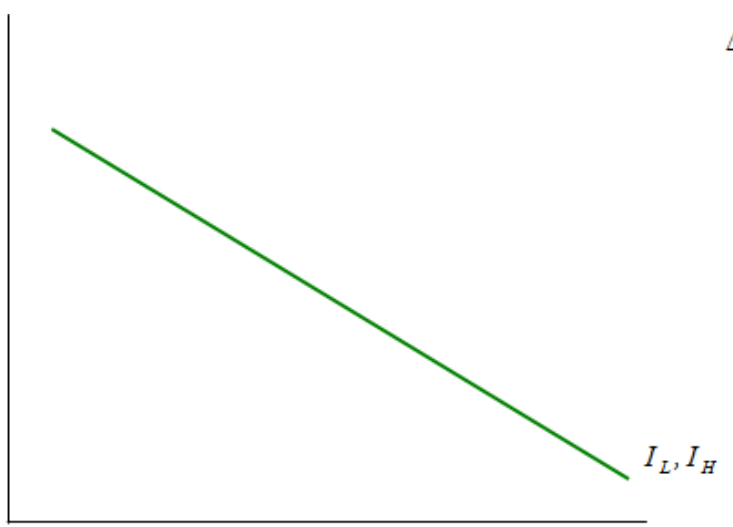

Rank

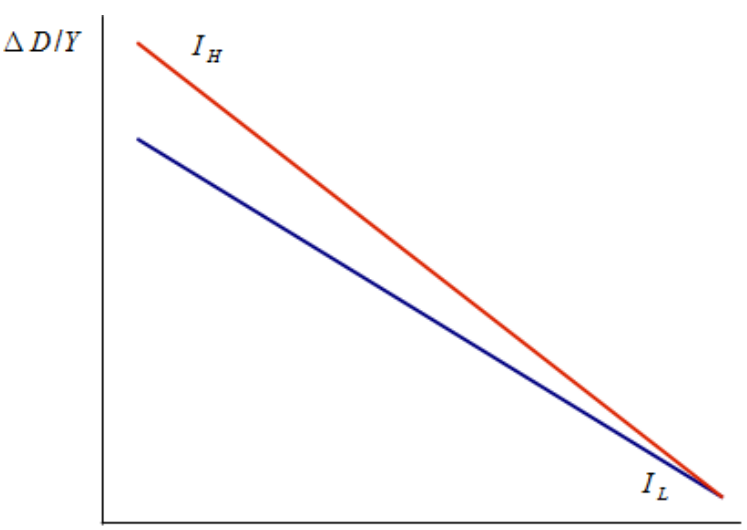

Rank

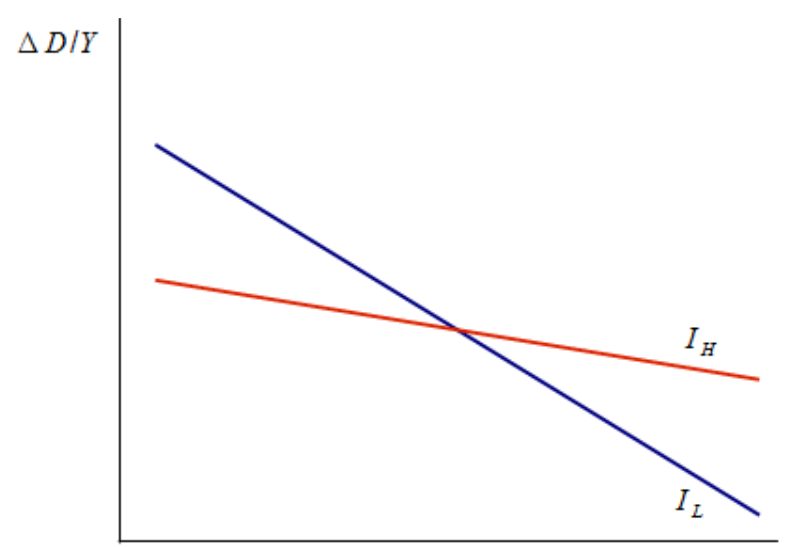

Rank

Note: The figure plots qualitative predictions for various theories of how borrowing and inequality interact. Panel A shows a case where the local inequality is irrelevant for borrowing. Panel B demonstrates a case when debt accumulation of the richest household does not depend on the local inequality and inequality increases overall debt accumulation. Panel C shows the case where increased inequality results in high-income households borrowing more and low-income households borrowing less. See section 3.1 in the text for details. 


\section{FIGURE 6: THE ESTIMATED EFFECT OF ONE SD INCREASE IN INEQUALITY ON DEBT ACCUMULATION $\boldsymbol{\sigma}($ Inequality $) *(\beta+\gamma *$ Rank $)$}

Panel A: Parsimonious Specification

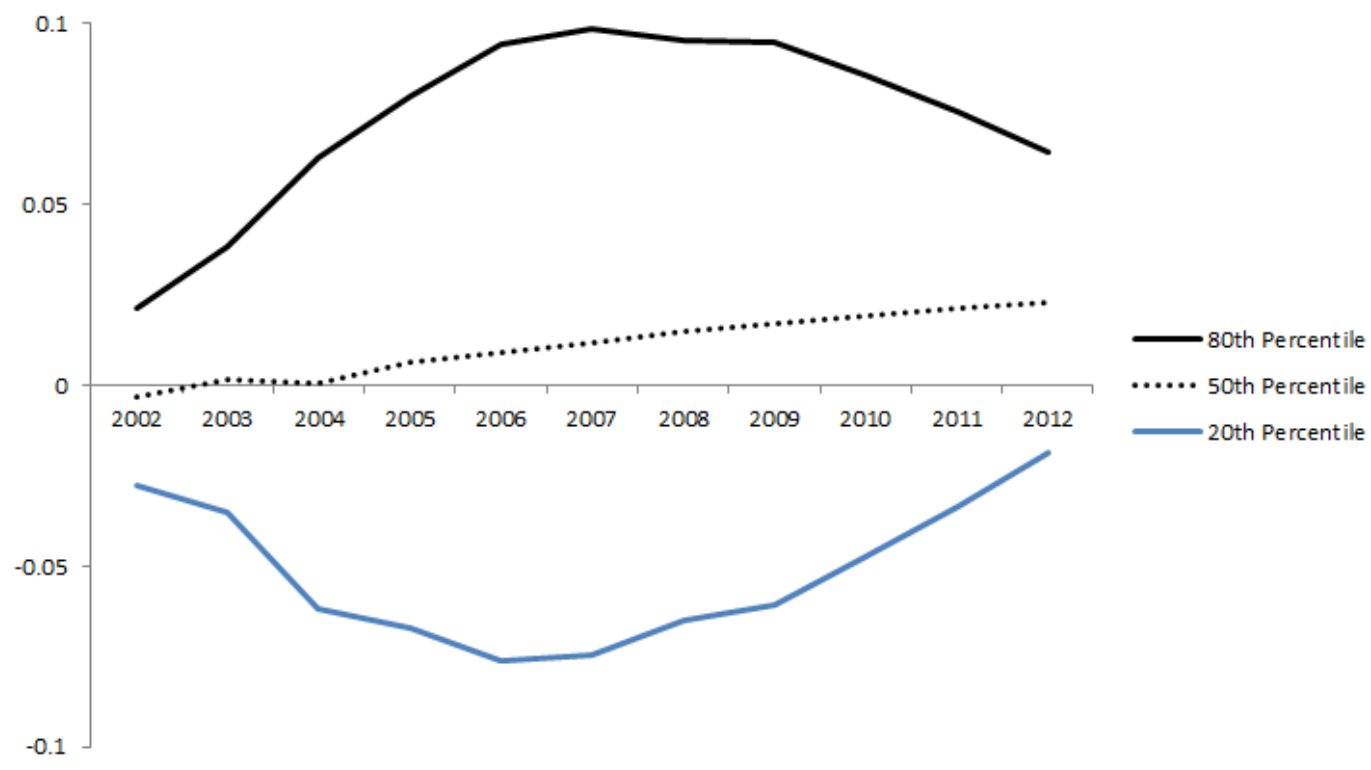

Panel B: Specification with Full Set of Controls

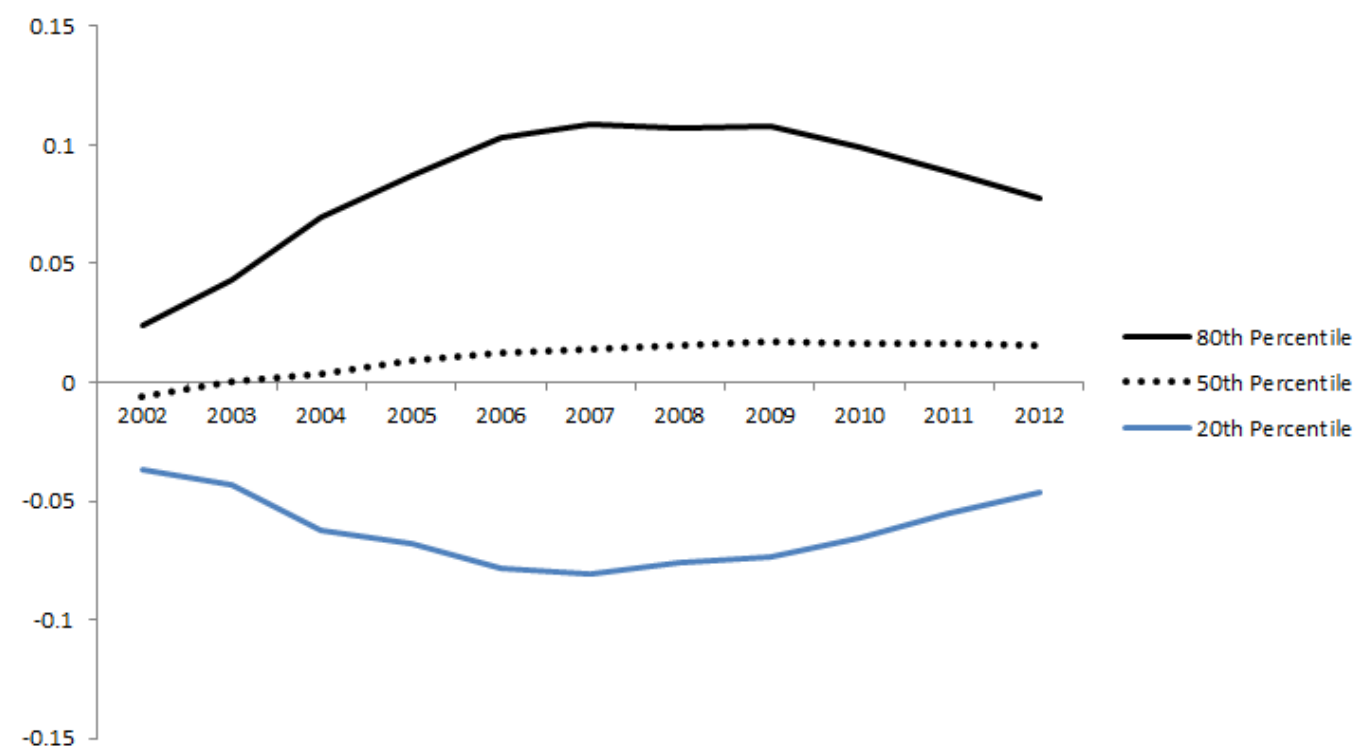

Note: These figures plot the calculated effects of a one standard deviation increase in inequality using estimated coefficients on rank, inequality, and the interaction of rank and inequality from the baseline specification (Table 3: Panel A) and the specification with full controls (Table 3: Panel C). 


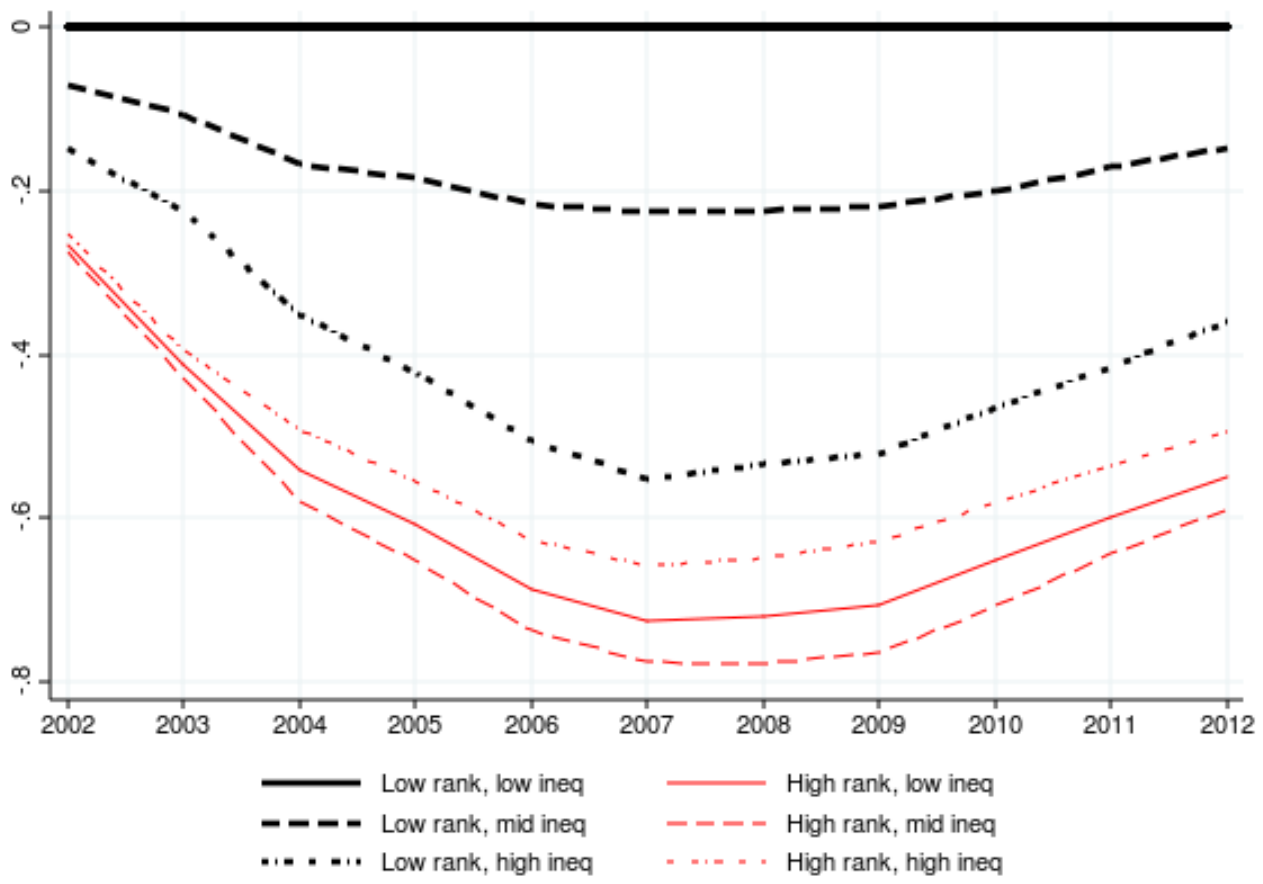

Note: The figure shows the estimated coefficients on the income rank dummies from the nonparametric regressions of the relative household debt accumulation between 2001 and year $t$. Each regression contains dummies for income ranks and inequality levels (with low-rank households in low-inequality regions being the benchmark), and a full set of controls described in equation (3) and the countyspecific fixed effects. Mid-rank households are not shown in Figure. See section 3.4 for details.

FIGURE 8. GROWTH OF AVERAGE INCOME WITHIN DECILE AND INEQUALITY
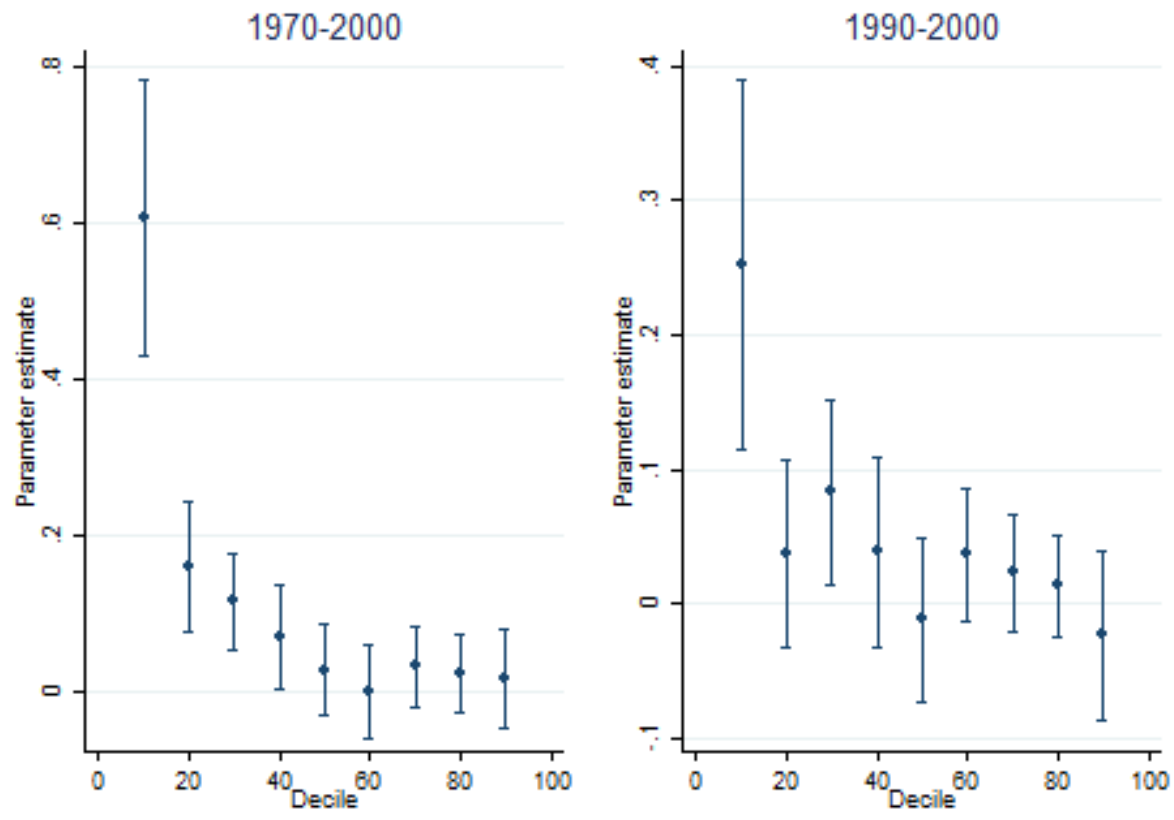

Note: The figure shows the estimated coefficients on inequality in the base year (i.e. 1970 or 1990) from regressing the log difference of average income within a decile across metro areas on measured inequality. Data are from IPUMS. Inequality is measured as the log P90/P10. Confidence intervals are at the 95\% level using heteroskedasticity-robust standard errors and each regression contains a constant. See section 3.7 and Appendix C for more details. 
Figure 9. TheOretical EFFECTS Of A CHANGE IN INEQUALITy ON PROVISION OF CREDIT

Bank Sorting and Inequality under Perfect Competition

Panel A

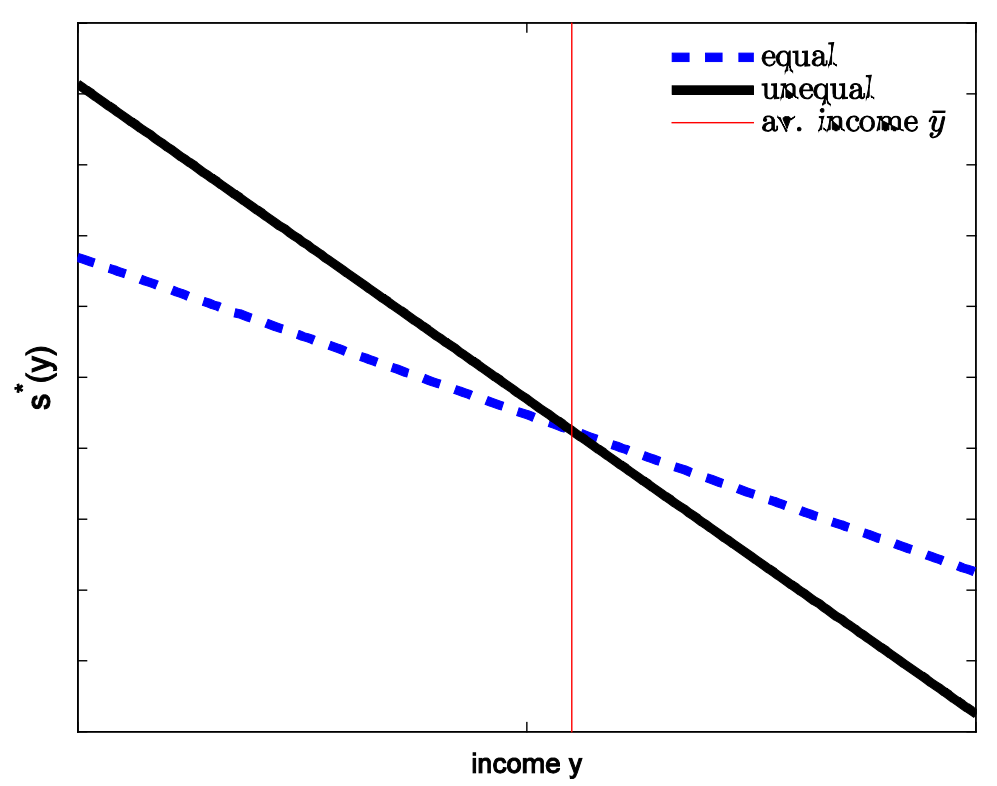

$\underline{\text { Panel B }}$

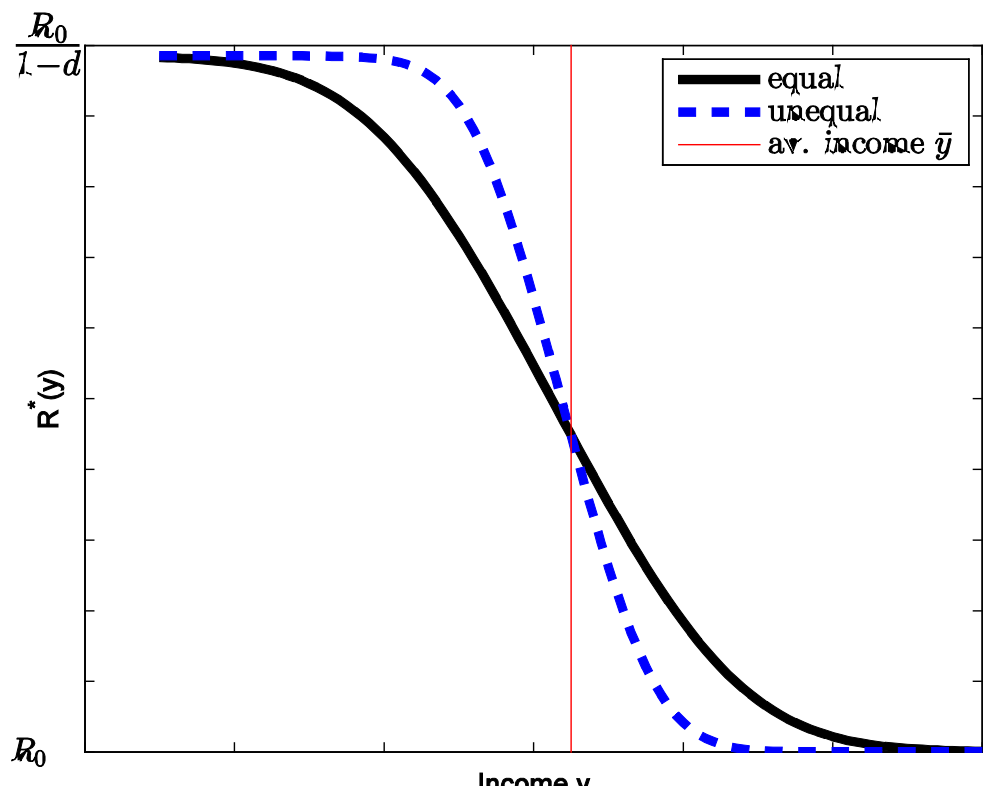

Income y

Bank Sorting and Inequality under Monopoly Banking

Panel C

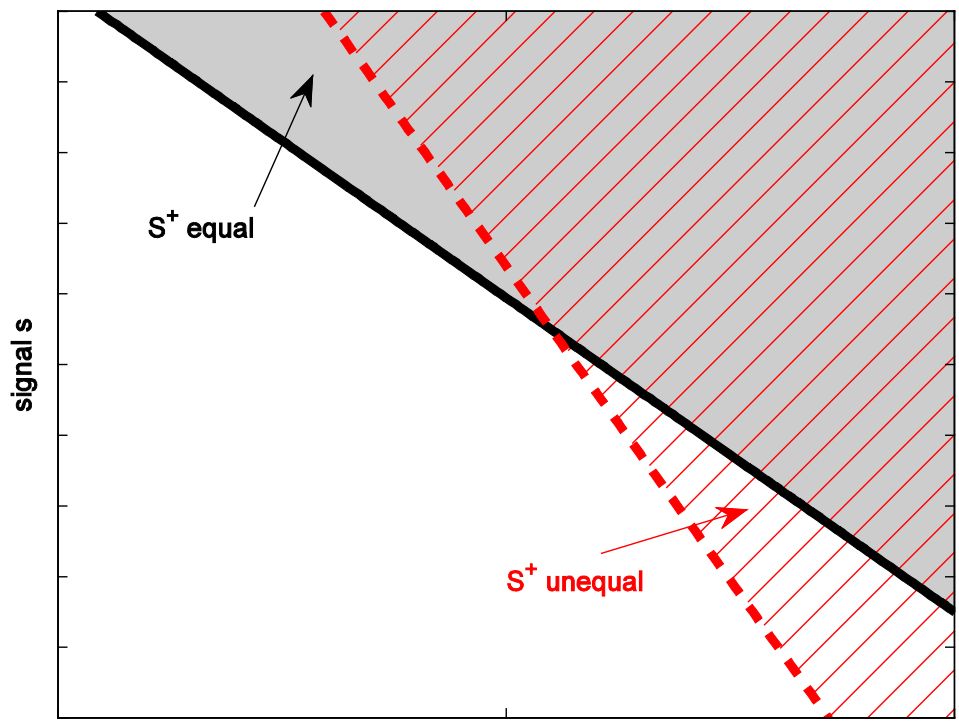

income $y$ $\underline{\text { Panel D }}$

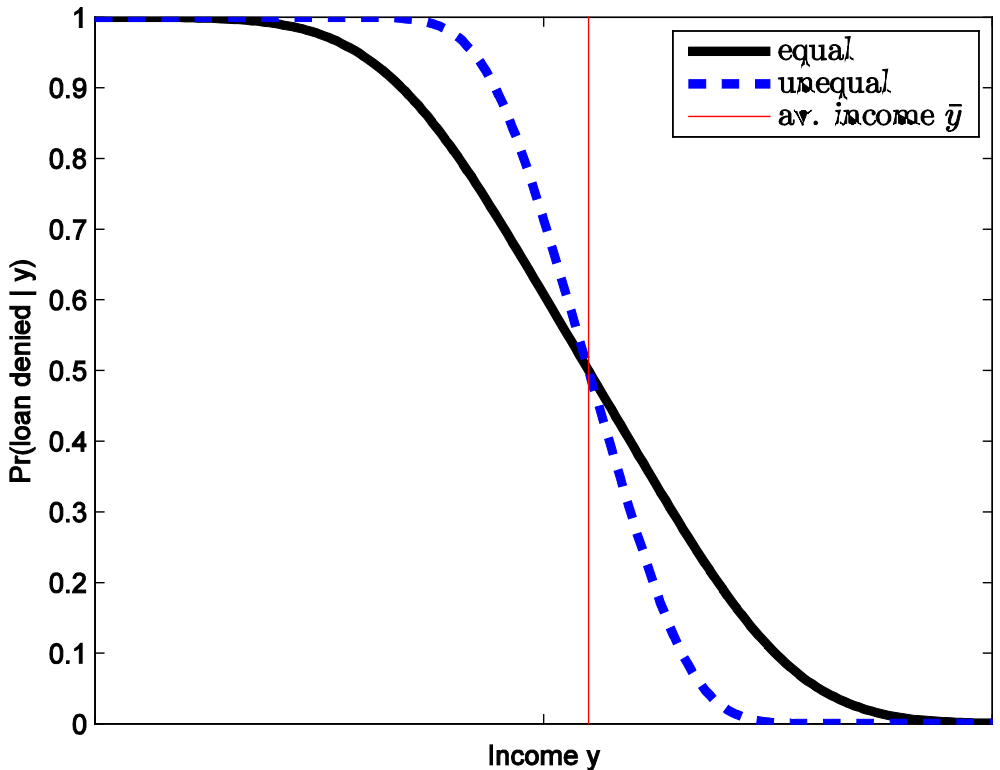

Note: Panel A shows the tradeoff $s^{*}(y)$ for baseline income distribution ("equal”) and more unequal income distribution ("unequal"). Panel B plots the interest rate for each income level and for different levels of income inequality. In Panels A and B banks can price discriminate perfectly. Panel C plots sets of households with signals $s$ and $y$ who obtain loans for two "equal" and "unequal" income distributions. Shaded regions indicate combinations of signals that yield an approved loan. Panel D plots loan deny probability as a function of income. In Panels C and D, the bank changes the same rate for all applicants. 


\begin{tabular}{|c|c|c|c|c|c|c|c|}
\hline \multirow[b]{2}{*}{ Category } & \multirow{2}{*}{ Mean } & \multirow{2}{*}{ St. Dev. } & \multicolumn{5}{|c|}{ Percentiles } \\
\hline & & & 10 & 25 & 50 & 75 & 90 \\
\hline \multicolumn{8}{|c|}{ Panel A: FRBNY Consumer Credit Panel/ Equifax, Q3 2001} \\
\hline $\begin{array}{l}\text { Age of head of } \\
\text { household }\end{array}$ & 42.6 & 11.0 & 28 & 34 & 42 & 51 & 58 \\
\hline Household size & 3.0 & 1.7 & 1 & 2 & 3 & 4 & 5 \\
\hline Housing debt & 56,423 & 99,938 & 0 & 0 & 12,351 & 83,255 & 156,082 \\
\hline Mortgage & 54,658 & 97,202 & 0 & 0 & 8,267 & 81,163 & 153,000 \\
\hline HELOC & 1,765 & 12,565 & 0 & 0 & 0 & 0 & 0 \\
\hline Auto loans & 6,876 & 11,543 & 0 & 0 & 0 & 10,805 & 21,376 \\
\hline Credit card limit & 30,459 & 36,452 & 1,609 & 6,127 & 19,320 & 42,288 & 73,009 \\
\hline Credit card balance & 8,884 & 14,812 & 261 & 1,120 & 3,923 & 10,881 & 22,893 \\
\hline Student loan & 1,639 & 7,849 & 0 & 0 & 0 & 0 & 2,723 \\
\hline Consumer financing & 929 & 5,861 & 0 & 0 & 0 & 178 & 2,033 \\
\hline Other debt & 4,044 & 22,158 & 0 & 0 & 0 & 0 & 10,410 \\
\hline Total debt & 78,794 & 112,167 & 1,368 & 9,437 & 42,311 & 111,335 & 193,395 \\
\hline Bankruptcy rate & 0.12 & 0.32 & 0.00 & 0.00 & 0.00 & 0.00 & 1.00 \\
\hline Delinquency rate & 0.30 & 0.46 & 0.00 & 0.00 & 0.00 & 1.00 & 1.00 \\
\hline $\begin{array}{l}\text { Credit card utilization } \\
\text { rate }\end{array}$ & 0.41 & 0.35 & 0.02 & 0.09 & 0.31 & 0.71 & 0.99 \\
\hline \multicolumn{8}{|c|}{ Panel B: Survey of Consumer Finances, 2001} \\
\hline $\begin{array}{l}\text { Age of head of } \\
\text { household }\end{array}$ & 43.3 & 11.3 & 28 & 35 & 43 & 52 & 59 \\
\hline Household size & 2.8 & 1.4 & 1 & 2 & 2 & 4 & 5 \\
\hline Housing debt & 60,783 & 119,310 & 0 & 0 & 29,000 & 90,000 & 150,000 \\
\hline Mortgage debt & 57,643 & 90,243 & 0 & 0 & 27,000 & 88,000 & 147,000 \\
\hline HELOC & 3,140 & 73,981 & 0 & 0 & 0 & 0 & 0 \\
\hline Auto loans & 5,182 & 8,280 & 0 & 0 & 0 & 8,700 & 18,000 \\
\hline Credit card limit & 19,290 & 43,636 & 1,400 & 4,500 & 10,000 & 22,000 & 42,000 \\
\hline Credit card balance & 2,586 & 5,459 & 0 & 0 & 500 & 3,000 & 7,200 \\
\hline Student loan & 2,271 & 9,786 & 0 & 0 & 0 & 0 & 5,000 \\
\hline $\begin{array}{l}\text { Consumer financing } \\
\text { Other debt }\end{array}$ & & & & & & & \\
\hline Total debt & 70,822 & 121,163 & 30 & 6,140 & 40,000 & 101,000 & 164,800 \\
\hline Bankruptcy rate & 0.10 & 0.30 & 0.00 & 0.00 & 0.00 & 0.00 & 1.00 \\
\hline Delinquency rate & 0.05 & 0.21 & 0.00 & 0.00 & 0.00 & 0.00 & 0.00 \\
\hline $\begin{array}{l}\text { Credit card utilization } \\
\text { rate }\end{array}$ & 0.27 & 0.34 & 0.00 & 0.00 & 0.08 & 0.47 & 0.93 \\
\hline
\end{tabular}

Note: The sample is restricted to the households with 20-65 year old head of household. The statistics are calculated using sampling weights. Housing debt is the sum of Mortgage and HELOC. The credit card limit is the maximum of the originally recorded credit card limit in the CCP and the credit card balance. The credit card utilization rate is calculated using this credit card limit. The table shows the statistics from the sample restricted to observations with nonzero credit card limit. The delinquency rate is a share of households with at least one member with an account that is 60 day past due or more. The number of observations in Panel A is 7,710,406. The number of observations in Panel B is 14,356. 
TABLE 2A: INCOME STATISTICS FROM SCF (ACTUAL) AND CCP (IMPUTED)

\begin{tabular}{lccccccc}
\hline \hline & \multirow{2}{*}{ Mean } & \multirow{2}{*}{ St. dev. } & \multicolumn{5}{c}{ Percentiles } \\
\cline { 4 - 8 } & & & 10 & 25 & 50 & 75 & 90 \\
\hline \hline Ln(Y), actual in SCF & 10.64 & 0.97 & 9.40 & 10.09 & 10.69 & 11.23 & 11.70 \\
Ln(Y), imputed in CCP & 10.91 & 1.18 & 9.55 & 10.15 & 10.81 & 11.51 & 12.36 \\
\hline \hline
\end{tabular}

Note: The sample is restricted to households with the 20-65 y.o. head of household and positive gross income. The sample in the SCF is further restricted to remove outliers. See text for more details.

TABLE 2B: SPEARMAN (RANK) CORRELATION BETWEEN ACTUAL AND IMPUTED INCOME

\begin{tabular}{cccccc}
\hline \hline & $\begin{array}{c}\text { Spearman } \\
\text { Correlation }\end{array}$ & $\mathrm{N}$ & & $\begin{array}{c}\text { Spearman } \\
\text { Correlation }\end{array}$ & $\mathrm{N}$ \\
\hline \hline Base & 0.88 & 2194 & & & \\
By Inequality: Imputed & & & By Region & & \\
& & & & & \\
Low & 0.85 & 725 & Northeast & 0.86 & 210 \\
Middle & 0.84 & 744 & Midwest & 0.83 & 665 \\
High & 0.84 & 725 & South & 0.87 & 1049 \\
& & & West & 0.87 & 270 \\
By Inequality: Census & & & & & \\
Low & 0.89 & 263 & & & \\
Middle & 0.82 & 267 & & & \\
High & 0.90 & 253 & & & \\
\end{tabular}

Note: The table reports the estimated Spearman correlations between the log of median household income and imputed median log household income at the county level for several samples. Base refers to the total sample. We also divide the counties into low, middle and high inequality counties where the counties are ranked by our own inequality measures and by Gini coefficients constructed by the Census. Finally, we divide counties into Census regions. See the text for more details. 
TABle 3: BASEline Results on Household DebT AcCumulation

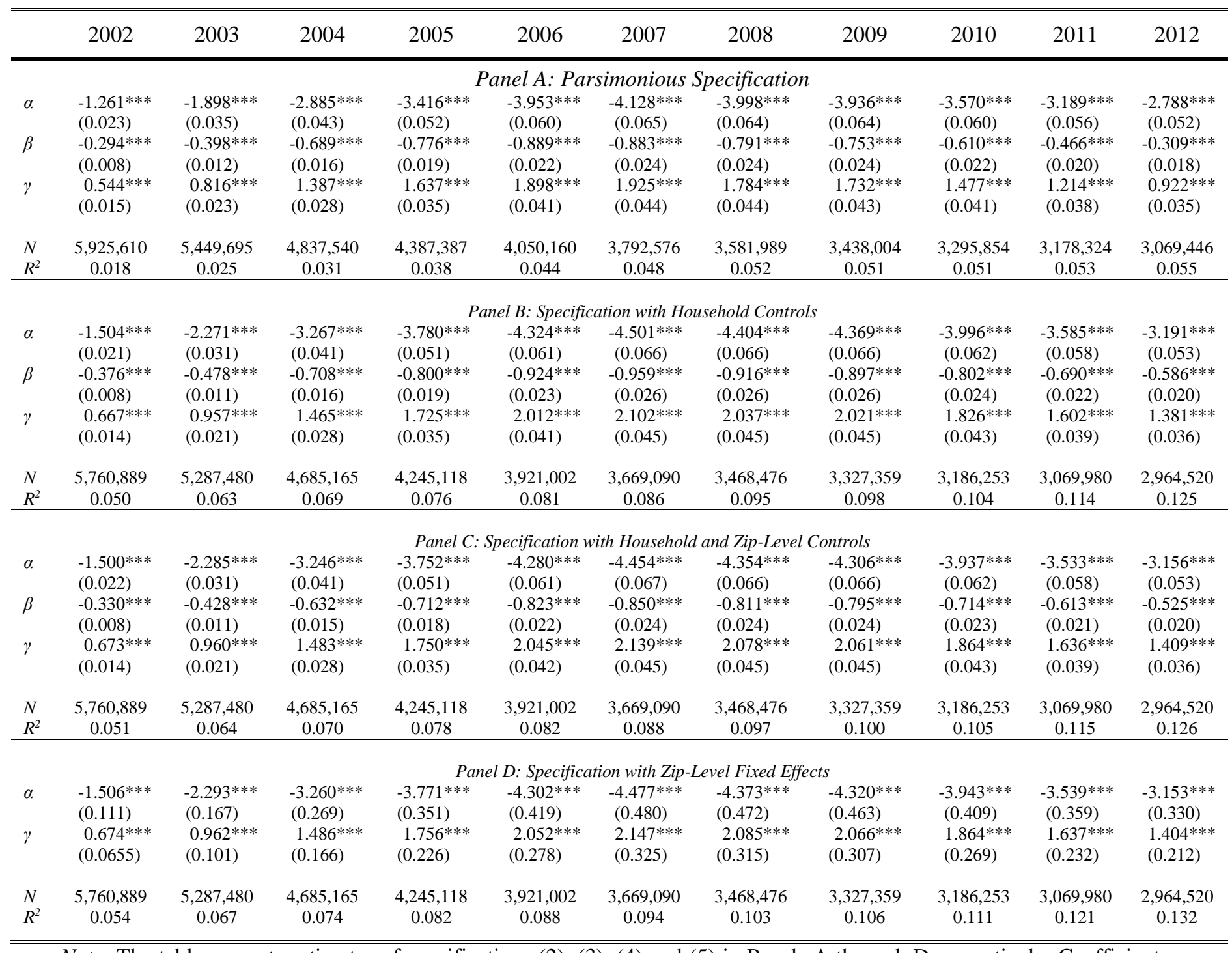

Note: The table presents estimates of specifications (2), (3), (4) and (5) in Panels A through D respectively. Coefficient $\alpha$ corresponds to the partial correlation of household income rank and debt accumulation between 2001 and the year indicated in each column (relative to household's 2001 income). Coefficient $\beta$ corresponds to the partial correlation of local inequality and household debt accumulation. Coefficient $\gamma$ is for the interaction of household income and local inequality. Each regression is run at the household level. Statistical significance at the $1 \%, 5 \%$, and $10 \%$ levels are indicated by ***, ${ }^{* *}$, and * respectively. In Panels A-C, the standard errors are clustered by zip code; in Panel D, standard errors are clustered by state. See sections 3.1 and 3.2 in the text for details. 
TABLE 4: INTERACTIONS OF RANK WITH CREDIT SCORES AND INITIAL DEBT LEVELS

\begin{tabular}{|c|c|c|c|c|c|c|c|c|c|c|c|}
\hline & 2002 & 2003 & 2004 & 2005 & 2006 & 2007 & 2008 & 2009 & 2010 & 2011 & 2012 \\
\hline & \multicolumn{11}{|c|}{ Panel A: Include Interaction of Household Credit Score and Local Inequality } \\
\hline$\alpha$ & $\begin{array}{l}-1.361 * * * \\
(0.023)\end{array}$ & $\begin{array}{l}-2.046 * * * \\
(0.033)\end{array}$ & $\begin{array}{l}-2.876 * * * \\
(0.044)\end{array}$ & $\begin{array}{l}-3.340 * * * \\
(0.053)\end{array}$ & $\begin{array}{l}-3.827 * * * \\
(0.062)\end{array}$ & $\begin{array}{l}-4.036^{* * *} \\
(0.068)\end{array}$ & $\begin{array}{l}-4.003^{* * *} \\
(0.067)\end{array}$ & $\begin{array}{l}-3.962 * * * \\
(0.067)\end{array}$ & $\begin{array}{l}-3.625 * * * \\
(0.063)\end{array}$ & $\begin{array}{l}-3.244 * * * \\
(0.058)\end{array}$ & $\begin{array}{l}-2.914 * * * \\
(0.053)\end{array}$ \\
\hline$\beta$ & $\begin{array}{l}-0.708^{* * *} \\
(0.019)\end{array}$ & $\begin{array}{l}-1.076 * * * \\
(0.030)\end{array}$ & $\begin{array}{l}-1.631 * * * \\
(0.041)\end{array}$ & $\begin{array}{l}-1.861^{* * *} \\
(0.051)\end{array}$ & $\begin{array}{l}-2.133^{* * *} \\
(0.064)\end{array}$ & $\begin{array}{l}-2.106^{* * *} \\
(0.074)\end{array}$ & $\begin{array}{l}-1.905^{* * *} \\
(0.078)\end{array}$ & $\begin{array}{l}-1.890^{* * *} \\
(0.079)\end{array}$ & $\begin{array}{l}-1.729 * * * \\
(0.074)\end{array}$ & $\begin{array}{l}-1.583 * * * \\
(0.069)\end{array}$ & $\begin{array}{l}-1.354 * * * \\
(0.065)\end{array}$ \\
\hline$\gamma$ & $\begin{array}{l}0.577^{* * *} \\
(0.015)\end{array}$ & $\begin{array}{l}0.795^{* * *} \\
(0.022)\end{array}$ & $\begin{array}{l}1.227^{* * *} \\
(0.029)\end{array}$ & $\begin{array}{l}1.465^{* * *} \\
(0.036)\end{array}$ & $\begin{array}{l}1.731^{* * *} \\
(0.043)\end{array}$ & $\begin{array}{l}1.849^{* * * *} \\
(0.047)\end{array}$ & $\begin{array}{l}1.835 * * * \\
(0.046)\end{array}$ & $\begin{array}{l}1.823^{* * *} \\
(0.046)\end{array}$ & $\begin{array}{l}1.647^{* * *} \\
(0.043)\end{array}$ & $\begin{array}{l}1.436 * * * \\
(0.039)\end{array}$ & $\begin{array}{l}1.241^{* * * *} \\
(0.036)\end{array}$ \\
\hline$\varphi$ & $\begin{array}{l}-0.307 * * * \\
(0.038)\end{array}$ & $\begin{array}{l}-0.690^{* * *} \\
(0.058)\end{array}$ & $\begin{array}{l}-1.386^{* * *} \\
(0.076)\end{array}$ & $\begin{array}{l}-1.727 * * * \\
(0.095)\end{array}$ & $\begin{array}{l}-2.128^{* * *} \\
(0.117)\end{array}$ & $\begin{array}{l}-2.007^{* * *} \\
(0.136)\end{array}$ & $\begin{array}{l}-1.553^{* * *} \\
(0.142)\end{array}$ & $\begin{array}{l}-1.359^{* * *} \\
(0.142)\end{array}$ & $\begin{array}{l}-1.269 * * * \\
(0.132)\end{array}$ & $\begin{array}{l}-1.281^{* * *} \\
(0.123)\end{array}$ & $\begin{array}{l}-1.113^{* * *} \\
(0.116)\end{array}$ \\
\hline$\sigma$ & $\begin{array}{l}0.512^{* * *} \\
(0.025)\end{array}$ & $\begin{array}{l}0.879 * * * \\
(0.039)\end{array}$ & $\begin{array}{l}1.353^{* * *} \\
(0.052)\end{array}$ & $\begin{array}{l}1.545^{* * *} \\
(0.065)\end{array}$ & $\begin{array}{l}1.751^{* * *} \\
(0.079)\end{array}$ & $\begin{array}{l}1.668^{* * *} \\
(0.092)\end{array}$ & $\begin{array}{l}1.445^{* * *} \\
(0.096)\end{array}$ & $\begin{array}{l}1.441^{* * *} \\
(0.097)\end{array}$ & $\begin{array}{l}1.333^{* * *} \\
(0.090)\end{array}$ & $\begin{array}{l}1.268^{* * *} \\
(0.083)\end{array}$ & $\begin{array}{l}1.082^{* * *} \\
(0.078)\end{array}$ \\
\hline $\begin{array}{l}N \\
R^{2} \\
\end{array}$ & $\begin{array}{c}5,760,889 \\
0.051 \\
\end{array}$ & $\begin{array}{c}5,287,480 \\
0.064 \\
\end{array}$ & $\begin{array}{c}4,685,165 \\
0.070 \\
\end{array}$ & $\begin{array}{c}4,245,118 \\
0.078 \\
\end{array}$ & $\begin{array}{c}3,921,002 \\
0.083 \\
\end{array}$ & $\begin{array}{c}3,669,090 \\
0.088 \\
\end{array}$ & $\begin{array}{c}3,468,476 \\
0.097 \\
\end{array}$ & $\begin{array}{c}3,327,359 \\
0.100 \\
\end{array}$ & $\begin{array}{c}3,186,253 \\
0.106 \\
\end{array}$ & $\begin{array}{c}3,069,980 \\
0.115 \\
\end{array}$ & $\begin{array}{c}2,964,520 \\
0.126 \\
\end{array}$ \\
\hline \multicolumn{12}{|c|}{ Panel B: Include Interaction of Initial Household Debt Level and Local Inequality } \\
\hline$\alpha$ & $\begin{array}{l}-0.516 * * * \\
(0.027)\end{array}$ & $\begin{array}{l}-1.171^{* * *} \\
(0.0387)\end{array}$ & $\begin{array}{l}-2.017^{* * *} \\
(0.0489)\end{array}$ & $\begin{array}{l}-2.422^{* * *} \\
(0.060)\end{array}$ & $\begin{array}{l}-2.970^{* * *} \\
(0.073)\end{array}$ & $\begin{array}{l}-3.069 * * * \\
(0.081)\end{array}$ & $\begin{array}{l}-2.916^{* * *} \\
(0.084)\end{array}$ & $\begin{array}{l}-2.814^{* * *} \\
(0.085)\end{array}$ & $\begin{array}{l}-2.316^{* * * *} \\
(0.080)\end{array}$ & $\begin{array}{l}-1.848 * * * \\
(0.076)\end{array}$ & $\begin{array}{l}-1.309 * * * \\
(0.071)\end{array}$ \\
\hline$\beta$ & $\begin{array}{l}-0.312^{* * *} \\
(0.011)\end{array}$ & $\begin{array}{l}-0.452^{* * *} \\
(0.017)\end{array}$ & $\begin{array}{l}-0.670 * * * \\
(0.022)\end{array}$ & $\begin{array}{l}-0.758^{* * *} \\
(0.027)\end{array}$ & $\begin{array}{l}-0.878^{* * *} \\
(0.032)\end{array}$ & $\begin{array}{l}-0.910^{* * * *} \\
(0.035)\end{array}$ & $\begin{array}{l}-0.881 * * * \\
(0.037)\end{array}$ & $\begin{array}{l}-0.857^{* * *} \\
(0.037)\end{array}$ & $\begin{array}{l}-0.770 * * * \\
(0.036)\end{array}$ & $\begin{array}{l}-0.659 * * * \\
(0.034)\end{array}$ & $\begin{array}{l}-0.556^{* * * *} \\
(0.032)\end{array}$ \\
\hline$\gamma$ & $\begin{array}{l}0.233^{* * *} \\
(0.020)\end{array}$ & $\begin{array}{l}0.530^{* * *} \\
(0.028)\end{array}$ & $\begin{array}{l}0.987 * * * \\
(0.035)\end{array}$ & $\begin{array}{l}1.203^{* * *} \\
(0.044)\end{array}$ & $\begin{array}{l}1.481^{* * *} \\
(0.054)\end{array}$ & $\begin{array}{l}1.529 * * * \\
(0.060)\end{array}$ & $\begin{array}{l}1.460^{* * *} \\
(0.062)\end{array}$ & $\begin{array}{l}1.433^{* * *} \\
(0.063)\end{array}$ & $\begin{array}{l}1.221^{* * *} \\
(0.059)\end{array}$ & $\begin{array}{l}1.014^{* * *} \\
(0.056)\end{array}$ & $\begin{array}{l}0.744^{* * *} \\
(0.052)\end{array}$ \\
\hline$\varphi$ & $\begin{array}{l}-2.97 * * * \\
(0.089)\end{array}$ & $\begin{array}{l}-3.79 * * * \\
(0.115)\end{array}$ & $\begin{array}{l}-4.09 * * * \\
(0.125)\end{array}$ & $\begin{array}{l}-4.47 * * * \\
(0.147)\end{array}$ & $\begin{array}{l}-4.59 * * * \\
(0.167)\end{array}$ & $\begin{array}{l}-5.00^{* * *} \\
(0.200)\end{array}$ & $\begin{array}{l}-5.37 * * * \\
(0.214)\end{array}$ & $\begin{array}{l}-5.49 * * * \\
(0.213)\end{array}$ & $\begin{array}{l}-6.05^{* * *} \\
(0.199)\end{array}$ & $\begin{array}{l}-6.21 * * * \\
(0.214)\end{array}$ & $\begin{array}{l}-6.876^{* * * *} \\
(0.195)\end{array}$ \\
\hline$\sigma$ & $\begin{array}{l}1.67 * * * \\
(0.063)\end{array}$ & $\begin{array}{l}2.15^{* * *} \\
(0.082)\end{array}$ & $\begin{array}{l}2.49 * * * \\
(0.891)\end{array}$ & $\begin{array}{l}2.81 * * * \\
(0.105)\end{array}$ & $\begin{array}{l}3.05^{* * *} \\
(0.122)\end{array}$ & $\begin{array}{l}3.38 * * * \\
(0.147)\end{array}$ & $\begin{array}{l}3.54 * * * \\
(0.158)\end{array}$ & $\begin{array}{l}3.55^{* * *} \\
(0.153)\end{array}$ & $\begin{array}{l}3.67 * * * \\
(0.144)\end{array}$ & $\begin{array}{l}3.53^{* * *} \\
(0.152)\end{array}$ & $\begin{array}{l}3.71^{* * *} \\
(0.140)\end{array}$ \\
\hline$N$ & $3,989,837$ & $3,643,849$ & $3,203,783$ & $2,882,349$ & $2,650,275$ & $2,470,570$ & 2,329,399 & $2,228,828$ & 2,128,927 & $2,047,809$ & $1,974,388$ \\
\hline$R^{2}$ & 0.053 & 0.061 & 0.064 & 0.070 & 0.074 & 0.079 & 0.088 & 0.091 & 0.098 & 0.109 & 0.124 \\
\hline
\end{tabular}

Note: The table presents estimates of specification (3') and (3') in section 3.2. Coefficient $\alpha$ corresponds to the partial correlation of household income rank and debt accumulation between 2001 and the year indicated in each column (relative to household's 2001 income). Coefficient $\beta$ corresponds to the partial correlation of local inequality and household debt accumulation. Coefficient $\gamma$ is for the interaction of household income and local inequality. Coefficient $\varphi$ represent the effects of each additional variable (household credit score in Panel A and initial household debt level in Panel B) while $\sigma$ captures the interaction of this household variable with local inequality. Each regression is run at the household level. Statistical significance at the $1 \%, 5 \%$, and $10 \%$ levels are indicated by ***, **, and * respectively . The standard errors are clustered by zip code. In Panel B, coefficients $\varphi$ and $\sigma$ and the respective standard errors are multiplied by $10^{\wedge} 6$. 
TABle 5: Household DebT ACCuMulation AlONG SubSETS OF DATA

\begin{tabular}{|c|c|c|c|c|c|c|}
\hline & & $\alpha$ & $\beta$ & $\gamma$ & $\mathrm{N}$ & $\begin{array}{l}R^{2} \\
\end{array}$ \\
\hline \multirow{5}{*}{$\begin{array}{l}\text { Grouping Zip Codes by } \\
\text { Census Region }\end{array}$} & Midwest & $\begin{array}{l}-3.352 * * * \\
(0.135)\end{array}$ & $\begin{array}{l}-0.434 * * * \\
(0.052)\end{array}$ & $\begin{array}{l}1.376^{* * *} \\
(0.096)\end{array}$ & 872,335 & 0.107 \\
\hline & Northeast & $-4.440 * * *$ & $-0.908^{* * *}$ & $2.316^{* * *}$ & 739,940 & 0.076 \\
\hline & & $(0.130)$ & $\begin{array}{l}(0.049) \\
0.07 * * *\end{array}$ & $\begin{array}{l}(0.094) \\
157 * * *\end{array}$ & 1328024 & 0.101 \\
\hline & (5) & $(0.126)$ & $(0.0443)$ & $(0.084)$ & דיד, & 0.101 \\
\hline & West & $\begin{array}{l}-6.233^{* * *} \\
(0.187)\end{array}$ & $\begin{array}{l}-1.369 * * * \\
(0.063)\end{array}$ & $\begin{array}{l}3.101 * * * \\
(0.121)\end{array}$ & 728,791 & 0.061 \\
\hline \multirow{3}{*}{$\begin{array}{l}\text { Grouping Zip Codes by } \\
\text { Average Credit Ratings }\end{array}$} & Low & $\begin{array}{l}-6.205^{* * *} \\
(0.146)\end{array}$ & $\begin{array}{l}-1.476^{* * *} \\
(0.041)\end{array}$ & $\begin{array}{l}3.375^{* * *} \\
(0.099)\end{array}$ & 999,984 & 0.093 \\
\hline & Middle & $-5.130 * * *$ & $-1.052 * * *$ & $2.548 * * *$ & $1,185,568$ & 0.102 \\
\hline & High & $\begin{array}{l}(0.106) \\
-2.515^{* * *} \\
(0.0705)\end{array}$ & $\begin{array}{l}(0.040) \\
-0.218^{* * *} \\
(0.028)\end{array}$ & $\begin{array}{l}(0.073) \\
1.214^{* * *} \\
(0.056)\end{array}$ & $1,483,538$ & 0.101 \\
\hline \multirow{3}{*}{$\begin{array}{l}\text { Grouping Zip Codes by } \\
\text { Initial Average Debt- } \\
\text { to-Income Ratios }\end{array}$} & Low & $-3.253 * * *$ & $-0.631 * * *$ & $1.512 * * *$ & 951,154 & 0.072 \\
\hline & Middle & $\begin{array}{l}(0.166) \\
-4.175^{* * *} \\
(0.120)\end{array}$ & $\begin{array}{l}(0.059) \\
-0.772^{* * *} \\
(0.044)\end{array}$ & $\begin{array}{l}(0.111) \\
1.933 * * * \\
(0.081)\end{array}$ & $1,244,905$ & 0.088 \\
\hline & High & $\begin{array}{l}-4.468 * * * \\
(0.0893)\end{array}$ & $\begin{array}{l}-0.834^{* * *} \\
(0.034)\end{array}$ & $\begin{array}{l}2.083 * * * \\
(0.062)\end{array}$ & $1,473,031$ & 0.100 \\
\hline \multirow{3}{*}{$\begin{array}{l}\text { Grouping Zip Codes by } \\
\text { House Price Growth } \\
\text { (2001-2005) }\end{array}$} & Low & $\begin{array}{l}-3.872 * * * \\
(0.135)\end{array}$ & $\begin{array}{l}-0.577 * * * \\
(0.051)\end{array}$ & $\begin{array}{l}1.677 * * * \\
(0.094)\end{array}$ & 836,451 & 0.114 \\
\hline & Middle & $\begin{array}{l}-5.136^{* * *} \\
(0.134)\end{array}$ & $\begin{array}{l}-1.024 * * * \\
(0.050)\end{array}$ & $\begin{array}{l}2.603 * * * \\
(0.091)\end{array}$ & 820,675 & 0.083 \\
\hline & High & $\begin{array}{l}-5.650 * * * \\
(0.179)\end{array}$ & $\begin{array}{l}-1.206^{* * *} \\
(0.061)\end{array}$ & $\begin{array}{l}2.828^{* * *} \\
(0.119)\end{array}$ & 799,557 & 0.061 \\
\hline \multirow{3}{*}{$\begin{array}{l}\text { Grouping Zip Codes by } \\
2001 \text { Average House } \\
\text { Price to Median Income } \\
\text { Ratio }\end{array}$} & Low & $\begin{array}{l}-4.707 * * * \\
(0.144)\end{array}$ & $\begin{array}{l}-0.915 * * * \\
(0.050)\end{array}$ & $\begin{array}{l}2.232 * * * \\
(0.093)\end{array}$ & 795,208 & 0.051 \\
\hline & Middle & $\begin{array}{l}-4.256^{* * *} \\
(0.150)\end{array}$ & $\begin{array}{l}-0.728 * * * \\
(0.057)\end{array}$ & $\begin{array}{l}1.847 * * * \\
(0.103)\end{array}$ & 830,645 & 0.103 \\
\hline & High & $\begin{array}{l}-3.702^{* * *} \\
(0.151)\end{array}$ & $\begin{array}{l}-0.566^{* * *} \\
(0.059)\end{array}$ & $\begin{array}{l}1.585^{* * *} \\
(0.106)\end{array}$ & 834,311 & 0.115 \\
\hline
\end{tabular}

Note: The table presents estimates of specification (4) in the text using household debt accumulation from 2001 to 2007. Panel A presents separate estimates for households located in each of four Census regions. Panel B presents estimates for households in zip codes with low, medium, or high initial average credit ratings. Panel C presents estimates for households in zip codes with low, medium, or high initial average debt-to-income ratios. Panel D decomposes zip codes by growth of house prices between 2001 and 2005. See section 3.3 in the text for details. Coefficient $\alpha$ corresponds to the partial correlation of household income rank and debt accumulation between 2001 and the year indicated in each column (relative to household's 2001 income). Coefficient $\beta$ corresponds to the partial correlation of local inequality and household debt accumulation. Coefficient $\gamma$ is for the interaction of household income and local inequality. Each regression is run at the household level. Statistical significance at the $1 \%, 5 \%$, and $10 \%$ levels are indicated by $* * *, * *$, and * respectively. The standard errors are clustered by zip code. 
TABLE 6: MEASURING INEQUALITY AT DifFERENT LEVELS OF AGgREgATION

\begin{tabular}{|c|c|c|c|c|c|c|c|c|c|c|c|}
\hline & 2002 & 2003 & 2004 & 2005 & 2006 & 2007 & 2008 & 2009 & 2010 & 2011 & 2012 \\
\hline & \multicolumn{11}{|c|}{ Panel A: Inequality at the County Level } \\
\hline$\alpha$ & $\begin{array}{l}-1.174 * * * \\
(0.0865)\end{array}$ & $\begin{array}{l}-2.073 * * * \\
(0.134)\end{array}$ & $\begin{array}{l}-3.108^{* * *} \\
(0.252)\end{array}$ & $\begin{array}{l}-3.949 * * * \\
(0.321)\end{array}$ & $\begin{array}{l}-4.756^{* * *} \\
(0.417)\end{array}$ & $\begin{array}{l}-5.179 * * * \\
(0.475)\end{array}$ & $\begin{array}{l}-5.055^{* * *} \\
(0.493)\end{array}$ & $\begin{array}{l}-4.996 * * * \\
(0.475)\end{array}$ & $\begin{array}{l}-4.560^{* * *} \\
(0.452)\end{array}$ & $\begin{array}{l}-4.176^{* * *} \\
(0.445)\end{array}$ & $\begin{array}{l}-3.631 * * * \\
(0.382)\end{array}$ \\
\hline$\beta$ & $\begin{array}{l}-0.241 * * * \\
(0.0423)\end{array}$ & $\begin{array}{l}-0.310^{* * *} \\
(0.0671)\end{array}$ & $\begin{array}{l}-0.456^{* * *} \\
(0.118)\end{array}$ & $\begin{array}{l}-0.548^{* * *} \\
(0.156)\end{array}$ & $\begin{array}{l}-0.570^{* * *} \\
(0.202)\end{array}$ & $\begin{array}{l}-0.578^{* *} \\
(0.232)\end{array}$ & $\begin{array}{l}-0.519 * * \\
(0.237)\end{array}$ & $\begin{array}{l}-0.501^{* *} \\
(0.227)\end{array}$ & $\begin{array}{l}-0.475^{* *} \\
(0.209)\end{array}$ & $\begin{array}{l}-0.467^{* *} \\
(0.200)\end{array}$ & $\begin{array}{l}-0.426^{* *} \\
(0.174)\end{array}$ \\
\hline$\gamma$ & $\begin{array}{l}0.583 * * * \\
(0.0606)\end{array}$ & $\begin{array}{l}0.986 * * * \\
(0.0943)\end{array}$ & $\begin{array}{l}1.531^{* * *} \\
(0.175)\end{array}$ & $\begin{array}{l}1.993^{* * *} \\
(0.224)\end{array}$ & $\begin{array}{l}2.413^{* * *} \\
(0.293)\end{array}$ & $\begin{array}{l}2.626 * * * \\
(0.334)\end{array}$ & $\begin{array}{l}2.545^{* * *} \\
(0.344)\end{array}$ & $\begin{array}{l}2.534^{* * *} \\
(0.330)\end{array}$ & $\begin{array}{l}2.343^{* * * *} \\
(0.314)\end{array}$ & $\begin{array}{l}2.170^{* * *} \\
(0.309)\end{array}$ & $\begin{array}{l}1.861^{* * *} \\
(0.264)\end{array}$ \\
\hline $\begin{array}{l}N \\
R^{2} \\
\end{array}$ & $\begin{array}{c}6,640,570 \\
0.048 \\
\end{array}$ & $\begin{array}{c}6,257,495 \\
0.060 \\
\end{array}$ & $\begin{array}{c}5,782,494 \\
0.070 \\
\end{array}$ & $\begin{array}{c}5,435,548 \\
0.079 \\
\end{array}$ & $\begin{array}{c}5,172,907 \\
0.086 \\
\end{array}$ & $\begin{array}{c}4,966,746 \\
0.091 \\
\end{array}$ & $\begin{array}{c}4,793,457 \\
0.098 \\
\end{array}$ & $\begin{array}{c}4,661,838 \\
0.100 \\
\end{array}$ & $\begin{array}{c}4,531,493 \\
0.105 \\
\end{array}$ & $\begin{array}{c}4,421,495 \\
0.115 \\
\end{array}$ & $\begin{array}{c}4,319,303 \\
0.125 \\
\end{array}$ \\
\hline & \multicolumn{11}{|c|}{ Panel B: Inequality at the State Level } \\
\hline$\alpha$ & $\begin{array}{l}-0.926 * * \\
(0.359)\end{array}$ & $\begin{array}{l}-1.710^{* * *} \\
(0.543)\end{array}$ & $\begin{array}{l}-2.852^{* *} \\
(1.114)\end{array}$ & $\begin{array}{l}-4.036^{* * *} \\
(1.412)\end{array}$ & $\begin{array}{l}-5.283^{* * *} \\
(1.667)\end{array}$ & $\begin{array}{l}-5.651^{* * *} \\
(1.697)\end{array}$ & $\begin{array}{l}-5.592^{* * *} \\
(1.612)\end{array}$ & $\begin{array}{l}-5.545^{* * *} \\
(1.525)\end{array}$ & $\begin{array}{l}-4.969 * * * \\
(1.476)\end{array}$ & $\begin{array}{l}-4.482^{* * *} \\
(1.391)\end{array}$ & $\begin{array}{l}-3.795 * * * \\
(1.224)\end{array}$ \\
\hline$\beta$ & $\begin{array}{r}0.0490 \\
(0.114)\end{array}$ & $\begin{array}{c}0.0832 \\
(0.163)\end{array}$ & $\begin{array}{c}0.254 \\
(0.259)\end{array}$ & $\begin{array}{c}0.478 \\
(0.324)\end{array}$ & $\begin{array}{l}0.839 * * \\
(0.394)\end{array}$ & $\begin{array}{l}1.317^{* * *} \\
(0.458)\end{array}$ & $\begin{array}{l}1.472 * * * \\
(0.469)\end{array}$ & $\begin{array}{l}1.386^{* * *} \\
(0.483)\end{array}$ & $\begin{array}{l}1.193^{* *} \\
(0.479)\end{array}$ & $\begin{array}{l}1.001^{* *} \\
(0.468)\end{array}$ & $\begin{array}{c}0.863^{*} \\
(0.447)\end{array}$ \\
\hline$\gamma$ & $\begin{array}{c}0.393 \\
(0.242)\end{array}$ & $\begin{array}{c}0.695 * \\
(0.367)\end{array}$ & $\begin{array}{c}1.280 * \\
(0.754)\end{array}$ & $\begin{array}{l}1.937^{* *} \\
(0.954)\end{array}$ & $\begin{array}{l}2.616^{* *} \\
(1.125)\end{array}$ & $\begin{array}{l}2.765^{* *} \\
(1.144)\end{array}$ & $\begin{array}{l}2.711^{* *} \\
(1.080)\end{array}$ & $\begin{array}{l}2.708^{* *} \\
(1.019)\end{array}$ & $\begin{array}{l}2.409 * * \\
(0.988)\end{array}$ & $\begin{array}{l}2.170^{* *} \\
(0.929)\end{array}$ & $\begin{array}{l}1.770^{* *} \\
(0.815)\end{array}$ \\
\hline$N$ & $7,015,125$ & $6,704,094$ & $6,344,116$ & $6,088,596$ & $5,893,406$ & $5,737,576$ & $5,600,035$ & $5,490,380$ & $5,383,103$ & $5,293,822$ & $5,209,929$ \\
\hline$R^{2}$ & 0.049 & 0.062 & 0.071 & 0.082 & 0.088 & 0.092 & 0.099 & 0.100 & 0.108 & 0.119 & 0.130 \\
\hline
\end{tabular}

Note: The table presents estimates of specification (4) while measuring inequality at different levels of aggregation: county level in Panel A and state level in Panel B. Coefficient $\alpha$ corresponds to the partial correlation of household income rank and debt accumulation between 2001 and the year indicated in each column (relative to household's 2001 income). Coefficient $\beta$ corresponds to the partial correlation of local inequality and household debt accumulation. Coefficient $\gamma$ is for the interaction of household income and local inequality. Each regression is run at the household level. Statistical significance at the 1\%, 5\%, and 10\% levels are indicated by ***, **, and * respectively. See section 3.4 in the text for details. 
TABLE 7: RESULTS BY FORM OF DEBT

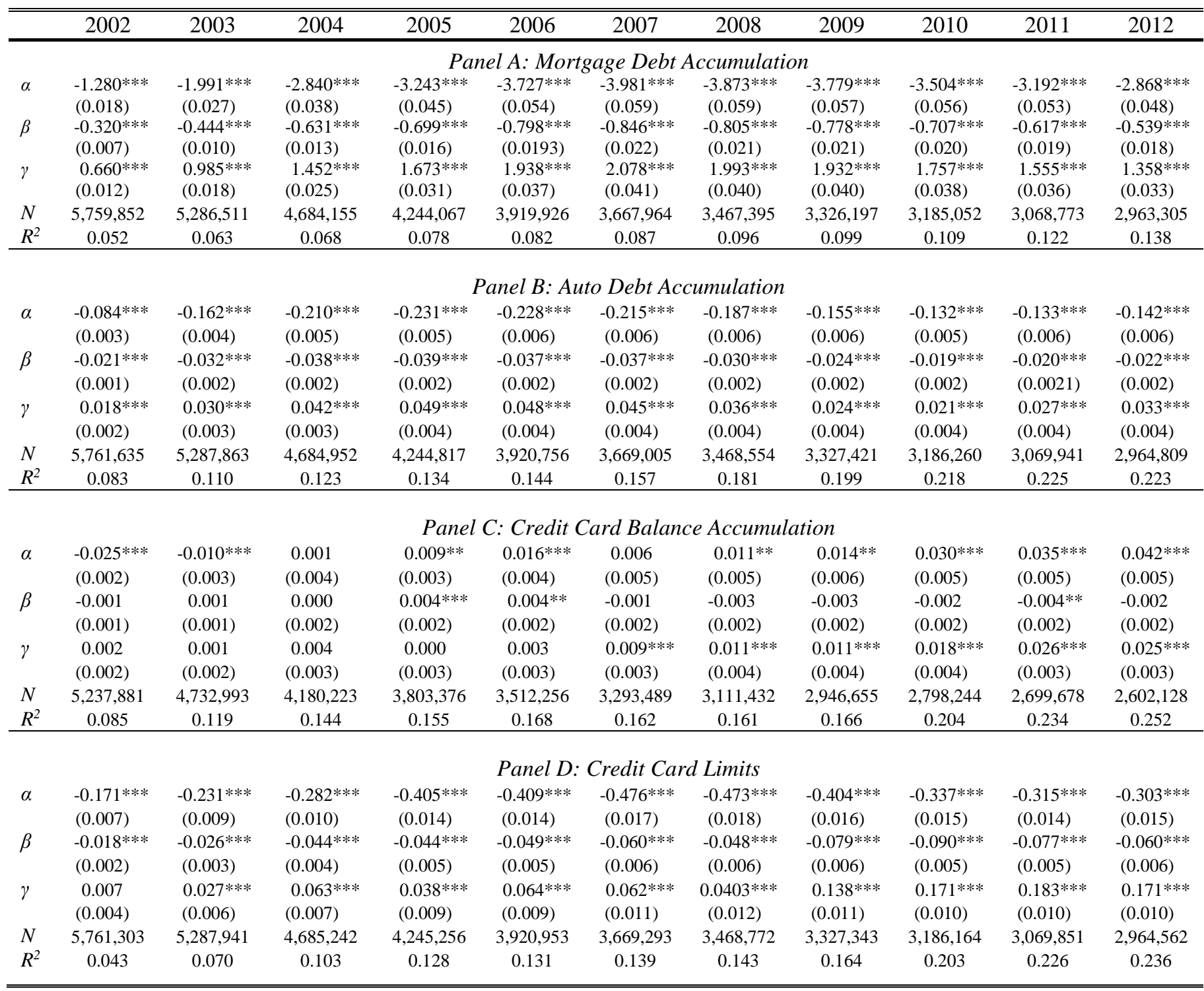

Note: The table presents estimates of specification (4) for different forms of household debt: mortgage debt in Panel A, auto debt in Panel B, credit card balances in Panel C and credit card limits in Panel D. Coefficient $\alpha$ corresponds to the partial correlation of household income rank and debt accumulation between 2001 and the year indicated in each column (relative to household's 2001 income). Coefficient $\beta$ corresponds to the partial correlation of local inequality and household debt accumulation. Coefficient $\gamma$ is for the interaction of household income and local inequality. Each regression is run at the household level. Statistical significance at the $1 \%, 5 \%$, and $10 \%$ levels are indicated by ***, **, and * respectively. See section 3.6 in the text for details. 
TABLE 8: MoRTGAgE APPLICATIONS AND LOCAL INEQUALITY

\begin{tabular}{|c|c|c|c|c|c|c|c|c|c|c|c|c|}
\hline & 2001 & 2002 & 2003 & 2004 & 2005 & 2006 & 2007 & 2008 & 2009 & 2010 & 2011 & 2012 \\
\hline \multicolumn{13}{|c|}{ Panel A: Probability of Mortgage Application Being Rejected } \\
\hline$\alpha$ & $\begin{array}{l}-0.295^{* * *} \\
(0.011)\end{array}$ & $\begin{array}{l}-0.232 * * * \\
(0.009)\end{array}$ & $\begin{array}{l}-0.192 * * * \\
(0.007)\end{array}$ & $\begin{array}{l}-0.194 * * * \\
(0.005)\end{array}$ & $\begin{array}{l}-0.199 * * * \\
(0.005)\end{array}$ & $\begin{array}{l}-0.159 * * * \\
(0.006)\end{array}$ & $\begin{array}{l}-0.129 * * * \\
(0.006)\end{array}$ & $\begin{array}{l}-0.141^{* * *} \\
(0.006)\end{array}$ & $\begin{array}{l}-0.129 * * * \\
(0.004)\end{array}$ & $\begin{array}{l}-0.181^{* * *} \\
(0.005)\end{array}$ & $\begin{array}{l}-0.201 * * * \\
(0.006)\end{array}$ & $\begin{array}{l}-0.207^{* * *} \\
(0.006)\end{array}$ \\
\hline$\gamma$ & $\begin{array}{l}-0.412^{* * *} \\
(0.086)\end{array}$ & $\begin{array}{l}-0.349 * * * \\
(0.070)\end{array}$ & $\begin{array}{l}-0.293^{* * *} \\
(0.051)\end{array}$ & $\begin{array}{l}-0.355^{* * *} \\
(0.037)\end{array}$ & $\begin{array}{l}-0.324^{* * *} \\
(0.034)\end{array}$ & $\begin{array}{l}-0.326 * * * \\
(0.036)\end{array}$ & $\begin{array}{l}-0.251^{* * *} \\
(0.035)\end{array}$ & $\begin{array}{l}-0.185^{* * *} \\
(0.038)\end{array}$ & $\begin{array}{l}-0.204^{* * *} \\
(0.029)\end{array}$ & $\begin{array}{l}-0.281^{* * *} \\
(0.034)\end{array}$ & $\begin{array}{l}-0.384^{* * *} \\
(0.041)\end{array}$ & $\begin{array}{l}-0.394^{* * *} \\
(0.039)\end{array}$ \\
\hline $\begin{array}{l}N \\
R^{2} \\
\end{array}$ & $\begin{array}{c}2,244,576 \\
0.121 \\
\end{array}$ & $\begin{array}{c}2,264,842 \\
0.092 \\
\end{array}$ & $\begin{array}{c}2,520,425 \\
0.066 \\
\end{array}$ & $\begin{array}{c}2,635,465 \\
0.061 \\
\end{array}$ & $\begin{array}{c}2,970,262 \\
0.055 \\
\end{array}$ & $\begin{array}{c}2,663,236 \\
0.056 \\
\end{array}$ & $\begin{array}{c}1,921,810 \\
0.058 \\
\end{array}$ & $\begin{array}{c}1,319,589 \\
0.047 \\
\end{array}$ & $\begin{array}{c}1,240,372 \\
0.040 \\
\end{array}$ & $\begin{array}{c}1,275,372 \\
0.052 \\
\end{array}$ & $\begin{array}{c}1,196,404 \\
0.068 \\
\end{array}$ & $\begin{array}{c}1,381,397 \\
0.078 \\
\end{array}$ \\
\hline \multicolumn{13}{|c|}{ Panel B: Loan-to-Income Ratios of Mortgage Originations } \\
\hline$\alpha$ & $\begin{array}{l}-0.587 * * * \\
(0.007)\end{array}$ & $\begin{array}{l}-0.623^{* * *} \\
(0.007)\end{array}$ & $\begin{array}{l}-0.656^{* * * *} \\
(0.007)\end{array}$ & $\begin{array}{l}-0.617^{* * *} \\
(0.007)\end{array}$ & $\begin{array}{l}-0.584^{* * * *} \\
(0.006)\end{array}$ & $\begin{array}{l}-0.598 * * * \\
(0.006)\end{array}$ & $\begin{array}{l}-0.644^{* * * *} \\
(0.006)\end{array}$ & $\begin{array}{l}-0.650 * * * \\
(0.006)\end{array}$ & $\begin{array}{l}-0.680^{* * *} \\
(0.006)\end{array}$ & $\begin{array}{l}-0.685^{* * *} \\
(0.006)\end{array}$ & $\begin{array}{l}-0.667 * * * \\
(0.007)\end{array}$ & $\begin{array}{l}-0.680^{* * *} \\
(0.007)\end{array}$ \\
\hline$\gamma$ & $\begin{array}{c}0.044 \\
(0.067)\end{array}$ & $\begin{array}{c}0.030 \\
(0.069)\end{array}$ & $\begin{array}{c}0.078 \\
(0.066)\end{array}$ & $\begin{array}{c}0.094 * \\
(0.050)\end{array}$ & $\begin{array}{c}0.019 \\
(0.044)\end{array}$ & $\begin{array}{c}0.014 \\
(0.044)\end{array}$ & $\begin{array}{l}0.095 * * \\
(0.041)\end{array}$ & $\begin{array}{c}0.070 \\
(0.049)\end{array}$ & $\begin{array}{c}0.005 \\
(0.052)\end{array}$ & $\begin{array}{c}0.073 \\
(0.054)\end{array}$ & $\begin{array}{c}0.049 \\
(0.058)\end{array}$ & $\begin{array}{c}0.028 \\
(0.060)\end{array}$ \\
\hline $\begin{array}{l}N \\
R^{2} \\
\end{array}$ & $\begin{array}{c}1,746,160 \\
0.327 \\
\end{array}$ & $\begin{array}{c}1,794,892 \\
0.349 \\
\end{array}$ & $\begin{array}{c}1,971,148 \\
0.371 \\
\end{array}$ & $\begin{array}{c}1,995,005 \\
0.352 \\
\end{array}$ & $\begin{array}{c}2,148,955 \\
0.336 \\
\end{array}$ & $\begin{array}{c}1,892,164 \\
0.349 \\
\end{array}$ & $\begin{array}{c}1,384,324 \\
0.371 \\
\end{array}$ & $\begin{array}{c}959,930 \\
0.380 \\
\end{array}$ & $\begin{array}{c}944,620 \\
0.403 \\
\end{array}$ & $\begin{array}{c}955,348 \\
0.408 \\
\end{array}$ & $\begin{array}{c}894,997 \\
0.390 \\
\end{array}$ & $\begin{array}{c}1,042,098 \\
0.394 \\
\end{array}$ \\
\hline \multicolumn{13}{|c|}{ Panel C: Log Distance Between Borrower and Lender } \\
\hline$\alpha$ & $\begin{array}{l}0.913 * * * \\
(0.220)\end{array}$ & $\begin{array}{l}1.032^{* * *} \\
(0.251)\end{array}$ & $\begin{array}{l}0.710^{* * *} \\
(0.211)\end{array}$ & $\begin{array}{l}0.611^{* *} \\
(0.238)\end{array}$ & $\begin{array}{l}1.105^{* * *} \\
(0.250)\end{array}$ & $\begin{array}{l}1.184^{* * *} \\
(0.231)\end{array}$ & $\begin{array}{l}0.934^{* * *} \\
(0.202)\end{array}$ & $\begin{array}{l}0.966 * * * \\
(0.191)\end{array}$ & $\begin{array}{l}0.742^{* * *} \\
(0.149)\end{array}$ & $\begin{array}{l}0.767 * * * \\
(0.179)\end{array}$ & $\begin{array}{l}0.869 * * * \\
(0.211)\end{array}$ & $\begin{array}{l}\text { NA } \\
\text { NA }\end{array}$ \\
\hline$\gamma$ & $\begin{array}{l}-0.511^{* * *} \\
(0.165)\end{array}$ & $\begin{array}{l}-0.593 * * * \\
(0.183)\end{array}$ & $\begin{array}{l}-0.391^{* *} \\
(0.154)\end{array}$ & $\begin{array}{l}-0.333^{*} \\
(0.174)\end{array}$ & $\begin{array}{l}-0.690 * * * \\
(0.186)\end{array}$ & $\begin{array}{l}-0.732 * * * \\
(0.170)\end{array}$ & $\begin{array}{l}-0.548^{* * * *} \\
(0.151)\end{array}$ & $\begin{array}{l}-0.569 * * * \\
(0.139)\end{array}$ & $\begin{array}{l}-0.422 * * * \\
(0.109)\end{array}$ & $\begin{array}{l}-0.431^{* * * *} \\
(0.131)\end{array}$ & $\begin{array}{l}-0.503^{* * * *} \\
(0.154)\end{array}$ & $\begin{array}{l}\text { NA } \\
\text { NA }\end{array}$ \\
\hline $\begin{array}{l}N \\
R^{2}\end{array}$ & $\begin{array}{c}512,500 \\
0.230\end{array}$ & $\begin{array}{c}521,088 \\
0.252\end{array}$ & $\begin{array}{c}670,197 \\
0.345\end{array}$ & $\begin{array}{c}682,968 \\
0.330\end{array}$ & $\begin{array}{c}680,922 \\
0.314\end{array}$ & $\begin{array}{c}592,749 \\
0.317\end{array}$ & $\begin{array}{c}613,608 \\
0.322\end{array}$ & $\begin{array}{c}454,283 \\
0.217\end{array}$ & $\begin{array}{c}499,269 \\
0.267\end{array}$ & $\begin{array}{c}518,390 \\
0.313\end{array}$ & $\begin{array}{c}491,535 \\
0,237\end{array}$ & $\begin{array}{l}\text { NA } \\
\text { NA }\end{array}$ \\
\hline \multicolumn{13}{|c|}{ Panel D: Probability of Mortgage Being High-Interest (conditional on origination) } \\
\hline$\alpha$ & & & & $\begin{array}{l}-0.139 * * * \\
(0.004)\end{array}$ & $\begin{array}{l}-0.221^{* * *} \\
(0.008)\end{array}$ & $\begin{array}{l}-0.181 * * * \\
(0.009)\end{array}$ & $\begin{array}{l}-0.127^{* * * *} \\
(0.006)\end{array}$ & $\begin{array}{l}-0.161 * * * \\
(0.005)\end{array}$ & $\begin{array}{l}-0.086^{* * * *} \\
(0.002)\end{array}$ & $\begin{array}{l}-0.080 * * * \\
(0.003)\end{array}$ & $\begin{array}{l}-0.102 * * * \\
(0.004)\end{array}$ & $\begin{array}{c}-0.102 * * * \\
(0.004)\end{array}$ \\
\hline$\gamma$ & & & & $\begin{array}{l}-0.196 * * * \\
(0.027)\end{array}$ & $\begin{array}{l}-0.246^{* * * *} \\
(0.039)\end{array}$ & $\begin{array}{l}-0.224 * * * \\
(0.039)\end{array}$ & $\begin{array}{l}-0.185^{* * * *} \\
(0.031)\end{array}$ & $\begin{array}{l}-0.135 * * * \\
(0.028)\end{array}$ & $\begin{array}{l}-0.076^{* * *} \\
(0.014)\end{array}$ & $\begin{array}{l}-0.110^{* * *} \\
(0.016)\end{array}$ & $\begin{array}{l}-0.137^{* * * *} \\
(0.022)\end{array}$ & $\begin{array}{c}-0.131 * * * \\
(0.024)\end{array}$ \\
\hline$N$ & & & & $1,995,005$ & $2,148,955$ & $1,892,164$ & $1,384,324$ & 959,930 & 944,620 & 955,348 & 894,997 & $1,042,098$ \\
\hline$R^{2}$ & & & & 0.110 & 0.173 & 0.138 & 0.080 & 0.065 & 0.047 & 0.082 & 0.082 & 0.084 \\
\hline
\end{tabular}

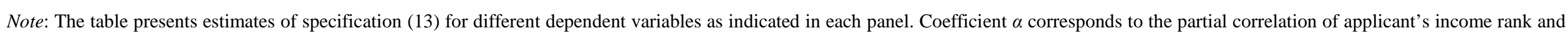

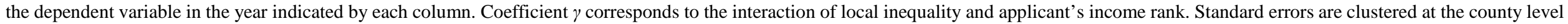

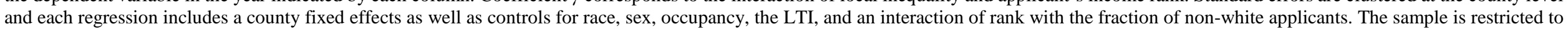

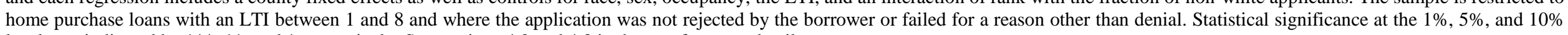
levels are indicated by $* * *, * *$, and $*$ respectively. See sections 4.2 and 4.3 in the text for more details. 
TABle 9: The Probability of a NeW Bank Branch Opening in a Census Tract

\begin{tabular}{cccc}
\hline \hline & No FE & Year FE & $\begin{array}{c}\text { Year and } \\
\text { State FE }\end{array}$ \\
\hline Census Tract Rank & & & \\
& -0.757 & -0.762 & -0.626 \\
County Inequality & $(0.578)$ & $(0.582)$ & $(0.588)$ \\
& & & \\
& -0.503 & -0.506 & $-1.292^{* * *}$ \\
& $(0.342)$ & $(0.344)$ & $(0.355)$ \\
Census Tract Rank $\times$ County Inequality & $0.946^{* *}$ & $0.952^{* *}$ & $0.877^{* *}$ \\
& $(0.415)$ & $(0.418)$ & $(0.416)$ \\
$N$ & & & \\
Pseudo- $R^{2}$ & 686,972 & 686,972 & 686,972 \\
\hline \hline
\end{tabular}

Note: The table presents estimates from a logit model for the probability that a new branch is opened in a census tract in a year. Each observation is a census tract-year combination and is equal to one if any new branch is opened in that census tract in that year. The primary variables of interest are the rank of the census tract within a county according to median income, our imputed measure of county inequality, and the interaction of inequality and rank. The estimates show that high-rank census tracts are more likely to get a new branch as inequality increases. The regressions also control for census tract demographics and ownership rates. Statistical significance at the $1 \%, 5 \%$, and $10 \%$ levels are indicated by ***, **, and * respectively.

TABLE 10: THE LOG P90/P10 RATIO OF INCOME IN 2000 AND EARLIER YEARS ACROSS METRO AREAS

\begin{tabular}{cccc}
\hline \hline & 1970 & 1980 & 1990 \\
\hline & & & \\
$\beta$ & $0.328^{* * *}$ & $0.697^{* * *}$ & $0.734^{* * *}$ \\
& $(0.062)$ & $(0.084)$ & $(0.064)$ \\
$N$ & 117 & 117 & 117 \\
$R^{2}$ & 0.204 & 0.379 & 0.526 \\
\hline \hline
\end{tabular}

Note: The table presents estimates of the extent to which lagged measured inequality predicts current measured inequality. For example, the column labeled 1970 regresses the log p90/p10 ratio for metro areas in 2000 on the same measure from 1970. The same metro areas are used in every year. Statistical significance at the $1 \%, 5 \%$, and $10 \%$ levels are indicated by ***, **, and * respectively. See section 4.4 in the text for more details. 


\title{
APPENDIX
}

\section{NOT FOR PUBLICATION}

\section{Does Greater Inequality Lead to More Household Borrowing? New Evidence from Household Data}

\author{
Olivier Coibion \\ UT Austin and NBER \\ ocoibion@austin.utexas.edu \\ Marianna Kudlyak \\ Federal Reserve Bank of San Francisco \\ marianna.kudlyak@sf.frb.org \\ Yuriy Gorodnichenko \\ UC Berkeley and NBER \\ ygorodni@econ.berkeley.edu \\ John Mondragon \\ Northwestern University \\ john.mondragon@kellogg.northwestern.edu
}

First Draft: December, 2013

This Draft: August, 2016 


\section{ApPendix A: AdDitional Tables AND Figures}

APPENDIX TABLE A1: RoBUSTNESS TO USING IRS MEASURE OF INEQUALITY

\begin{tabular}{|c|c|c|c|c|c|c|c|c|c|c|c|}
\hline & 2002 & 2003 & 2004 & 2005 & 2006 & 2007 & 2008 & 2009 & 2010 & 2011 & 2012 \\
\hline & \multicolumn{11}{|c|}{ Panel A: Parsimonious Specification } \\
\hline$\alpha$ & $\begin{array}{l}-1.253^{* * *} \\
(0.0226)\end{array}$ & $\begin{array}{l}-1.979 * * * \\
(0.0339)\end{array}$ & $\begin{array}{l}-2.583^{* * *} \\
(0.0450)\end{array}$ & $\begin{array}{l}-3.012 * * * \\
(0.0540)\end{array}$ & $\begin{array}{l}-3.382 * * * \\
(0.0643)\end{array}$ & $\begin{array}{l}-3.515 * * * \\
(0.0698)\end{array}$ & $\begin{array}{l}-3.494 * * * \\
(0.0701)\end{array}$ & $\begin{array}{l}-3.496 * * * \\
(0.0686)\end{array}$ & $\begin{array}{l}-3.397 * * * \\
(0.0645)\end{array}$ & $\begin{array}{l}-3.246 * * * \\
(0.0588)\end{array}$ & $\begin{array}{l}-3.066^{* * *} \\
(0.0538)\end{array}$ \\
\hline$\beta$ & $\begin{array}{l}-0.989 * * * \\
(0.0273)\end{array}$ & $\begin{array}{l}-1.443^{* * *} \\
(0.0400)\end{array}$ & $\begin{array}{l}-2.071^{* * *} \\
(0.0569)\end{array}$ & $\begin{array}{l}-2.328^{* * *} \\
(0.0678)\end{array}$ & $\begin{array}{l}-2.574 * * * \\
(0.0824)\end{array}$ & $\begin{array}{l}-2.579 * * * \\
(0.0884)\end{array}$ & $\begin{array}{l}-2.375^{* * *} \\
(0.0896)\end{array}$ & $\begin{array}{l}-2.271^{* * *} \\
(0.0879)\end{array}$ & $\begin{array}{l}-2.024^{* * *} \\
(0.0814)\end{array}$ & $\begin{array}{l}-1.776^{* * *} \\
(0.0731)\end{array}$ & $\begin{array}{l}-1.465^{* * *} \\
(0.0665)\end{array}$ \\
\hline$\gamma$ & $\begin{array}{l}1.840 * * * \\
(0.0507)\end{array}$ & $\begin{array}{c}2.972 * * * \\
(0.0761)\end{array}$ & $\begin{array}{l}4.036^{* * *} \\
(0.101)\end{array}$ & $\begin{array}{l}4.646^{* * *} \\
(0.121)\end{array}$ & $\begin{array}{l}5.141^{* * *} \\
(0.144)\end{array}$ & $\begin{array}{l}5.133^{* * *} \\
(0.156)\end{array}$ & $\begin{array}{l}4.901 * * * \\
(0.157)\end{array}$ & $\begin{array}{l}4.872^{* * *} \\
(0.154)\end{array}$ & $\begin{array}{l}4.620^{* * *} \\
(0.146)\end{array}$ & $\begin{array}{l}4.256^{* * *} \\
(0.133)\end{array}$ & $\begin{array}{l}3.772^{* * *} \\
(0.122)\end{array}$ \\
\hline $\begin{array}{l}N \\
R^{2} \\
\end{array}$ & $\begin{array}{c}5,924,528 \\
0.019 \\
\end{array}$ & $\begin{array}{c}5,448,827 \\
0.025 \\
\end{array}$ & $\begin{array}{c}4,837,107 \\
0.031 \\
\end{array}$ & $\begin{array}{c}4,387,141 \\
0.037 \\
\end{array}$ & $\begin{array}{c}4,049,986 \\
0.044 \\
\end{array}$ & $\begin{array}{c}3,792,441 \\
0.048 \\
\end{array}$ & $\begin{array}{c}3,581,901 \\
0.052 \\
\end{array}$ & $\begin{array}{c}3,437,924 \\
0.051 \\
\end{array}$ & $\begin{array}{c}3,295,791 \\
0.051 \\
\end{array}$ & $\begin{array}{c}3,178,262 \\
0.053 \\
\end{array}$ & $\begin{array}{c}3,069,405 \\
0.055 \\
\end{array}$ \\
\hline & \multicolumn{11}{|c|}{ Panel B: Specification with Household and Regional Controls } \\
\hline$\alpha$ & $\begin{array}{l}-1.111 * * * \\
(0.0239)\end{array}$ & $\begin{array}{l}-1.864 * * * \\
(0.0347)\end{array}$ & $\begin{array}{l}-2.504 * * * \\
(0.0481)\end{array}$ & $\begin{array}{l}-2.903^{* * *} \\
(0.0582)\end{array}$ & $\begin{array}{l}-3.294 * * * \\
(0.0697)\end{array}$ & $\begin{array}{l}-3.398 * * * \\
(0.0756)\end{array}$ & $\begin{array}{l}-3.348 * * * \\
(0.0760)\end{array}$ & $\begin{array}{l}-3.350^{* * *} \\
(0.0749)\end{array}$ & $\begin{array}{l}-3.131 * * * \\
(0.0714)\end{array}$ & $\begin{array}{l}-2.861^{* * *} \\
(0.0656)\end{array}$ & $\begin{array}{l}-2.602 * * * \\
(0.0596)\end{array}$ \\
\hline$\beta$ & $\begin{array}{l}-0.735 * * * \\
(0.0285)\end{array}$ & $\begin{array}{l}-1.066 * * * \\
(0.0406)\end{array}$ & $\begin{array}{l}-1.482 * * * \\
(0.0571)\end{array}$ & $\begin{array}{l}-1.690 * * * \\
(0.0690)\end{array}$ & $\begin{array}{l}-1.918 * * * \\
(0.0848)\end{array}$ & $\begin{array}{l}-1.941^{* * *} \\
(0.0923)\end{array}$ & $\begin{array}{l}-1.828^{* * * *} \\
(0.0940)\end{array}$ & $\begin{array}{l}-1.802 * * * \\
(0.0937)\end{array}$ & $\begin{array}{l}-1.662 * * * \\
(0.0891)\end{array}$ & $\begin{array}{l}-1.475^{* * *} \\
(0.0822)\end{array}$ & $\begin{array}{l}-1.280^{* * *} \\
(0.0767)\end{array}$ \\
\hline$\gamma$ & $\begin{array}{l}1.399 * * * \\
(0.0535)\end{array}$ & $\begin{array}{c}2.309 * * * \\
(0.0782)\end{array}$ & $\begin{array}{l}3.349 * * * \\
(0.109)\end{array}$ & $\begin{array}{l}4.014 * * * \\
(0.132)\end{array}$ & $\begin{array}{l}4.702 * * * \\
(0.159)\end{array}$ & $\begin{array}{l}4.856^{* * *} \\
(0.172)\end{array}$ & $\begin{array}{l}4.764^{* * *} \\
(0.173)\end{array}$ & $\begin{array}{l}4.822 * * * \\
(0.171)\end{array}$ & $\begin{array}{l}4.498 * * * \\
(0.164)\end{array}$ & $\begin{array}{l}4.033^{* * *} \\
(0.151)\end{array}$ & $\begin{array}{l}3.527^{* * *} \\
(0.137)\end{array}$ \\
\hline$N$ & $5,759,823$ & $5,286,632$ & $4,684,753$ & $4,244,903$ & $3,920,861$ & $3,668,986$ & $3,468,411$ & $3,327,299$ & $3,186,211$ & $3,069,940$ & $2,964,489$ \\
\hline$R^{2}$ & 0.051 & 0.063 & 0.069 & 0.077 & 0.082 & 0.087 & 0.096 & 0.099 & 0.105 & 0.115 & 0.126 \\
\hline
\end{tabular}

Note: The table reproduces the results in Table 3 of the text using the IRS measure of inequality rather than the CCP measure. See section 3.2 in the text for details. 
APPENDIX TABLE A2: ALTERNATIVE SPECIFICATIONS

\begin{tabular}{|c|c|c|c|c|c|c|c|c|c|c|c|}
\hline & 2002 & 2003 & 2004 & 2005 & 2006 & 2007 & 2008 & 2009 & 2010 & 2011 & 2012 \\
\hline & \multicolumn{11}{|c|}{ Panel A: Inverse of Expected Income Replaces Rank } \\
\hline$\alpha$ & $\begin{array}{l}12,256 * * * \\
(322.6)\end{array}$ & $\begin{array}{l}20,148^{* * *} \\
(532.1)\end{array}$ & $\begin{array}{l}31,725^{* * *} \\
(709.6)\end{array}$ & $\begin{array}{l}41,280^{* * *} \\
(888.7)\end{array}$ & $\begin{array}{l}51,544^{* * *} \\
(1,092)\end{array}$ & $\begin{array}{l}57,399 * * * \\
(1,236)\end{array}$ & $\begin{array}{l}57,878^{* * *} \\
(1,285)\end{array}$ & $\begin{array}{l}57,950 * * * \\
(1,280)\end{array}$ & $\begin{array}{l}54,275^{* * *} \\
(1,226)\end{array}$ & $\begin{array}{l}49,893^{* * *} \\
(1,162)\end{array}$ & $\begin{array}{l}45,220 * * * \\
(1,104)\end{array}$ \\
\hline$\beta$ & $\begin{array}{c}0.0232 * * * \\
(0.00501)\end{array}$ & $\begin{array}{c}0.0949 * * * \\
(0.00775)\end{array}$ & $\begin{array}{l}0.184^{* * *} \\
(0.0104)\end{array}$ & $\begin{array}{c}0.285^{* * *} \\
(0.0125)\end{array}$ & $\begin{array}{c}0.373^{* * *} \\
(0.0154)\end{array}$ & $\begin{array}{c}0.417^{* * *} \\
(0.0171)\end{array}$ & $\begin{array}{l}0.413^{* * *} \\
(0.0176)\end{array}$ & $\begin{array}{l}0.418^{* * *} \\
(0.0174)\end{array}$ & $\begin{array}{l}0.384^{* * *} \\
(0.0168)\end{array}$ & $\begin{array}{c}0.340 * * * \\
(0.0160)\end{array}$ & $\begin{array}{c}0.285^{* * *} \\
(0.0151)\end{array}$ \\
\hline$N$ & $5,925,610$ & $5,449,695$ & $4,837,540$ & $4,387,387$ & $4,050,160$ & $3,792,576$ & 3,581,989 & $3,438,004$ & $3,295,854$ & $3,178,324$ & $3,069,446$ \\
\hline$R^{2}$ & 0.009 & 0.013 & 0.017 & 0.023 & 0.030 & 0.035 & 0.038 & 0.037 & 0.037 & 0.038 & 0.040 \\
\hline \multicolumn{12}{|c|}{ Panel B: Outcome is the Log Difference of Debt } \\
\hline$\alpha$ & $\begin{array}{c}-0.968 * * * \\
(0.0468)\end{array}$ & $\begin{array}{c}-1.052^{* * *} \\
(0.0533)\end{array}$ & $\begin{array}{c}-1.138 * * * \\
(0.0606)\end{array}$ & $\begin{array}{c}-1.087 * * * \\
(0.0655)\end{array}$ & $\begin{array}{c}-1.072^{* * *} \\
(0.0704)\end{array}$ & $\begin{array}{c}-1.052^{* * *} \\
(0.0756)\end{array}$ & $\begin{array}{c}-1.003^{* * *} \\
(0.0789)\end{array}$ & $\begin{array}{c}-1.032^{* * *} \\
(0.0830)\end{array}$ & $\begin{array}{c}-0.979 * * * \\
(0.0865)\end{array}$ & $\begin{array}{c}-0.688^{* * *} \\
(0.0878)\end{array}$ & $\begin{array}{c}-0.497 * * * \\
(0.0888)\end{array}$ \\
\hline$\beta$ & $\begin{array}{c}-0.224^{* * *} \\
(0.0180)\end{array}$ & $\begin{array}{c}-0.220 * * * \\
(0.0245)\end{array}$ & $\begin{array}{c}-0.271^{* * *} \\
(0.0280)\end{array}$ & $\begin{array}{c}-0.190 * * * \\
(0.0304)\end{array}$ & $\begin{array}{c}-0.131^{* * *} \\
(0.0328)\end{array}$ & $\begin{array}{c}-0.143^{* * *} \\
(0.0358)\end{array}$ & $\begin{array}{c}-0.0965^{* * *} \\
(0.0372)\end{array}$ & $\begin{array}{c}-0.0860 * * \\
(0.0391)\end{array}$ & $\begin{array}{l}-0.0696 * \\
(0.0407)\end{array}$ & $\begin{array}{c}0.0652 \\
(0.0408)\end{array}$ & $\begin{array}{c}0.157 * * * \\
(0.0411)\end{array}$ \\
\hline$\gamma$ & $\begin{array}{c}0.305^{* * *} \\
(0.0317)\end{array}$ & $\begin{array}{c}0.317^{* * *} \\
(0.0392)\end{array}$ & $\begin{array}{c}0.375^{* * *} \\
(0.0445)\end{array}$ & $\begin{array}{c}0.305^{* * *} \\
(0.0482)\end{array}$ & $\begin{array}{c}0.284 * * * \\
(0.0519)\end{array}$ & $\begin{array}{c}0.275^{* * *} \\
(0.0559)\end{array}$ & $\begin{array}{c}0.252 * * * \\
(0.0584)\end{array}$ & $\begin{array}{c}0.280 * * * \\
(0.0615)\end{array}$ & $\begin{array}{c}0.258 * * * \\
(0.0641)\end{array}$ & $\begin{array}{c}0.0548 \\
(0.0652)\end{array}$ & $\begin{array}{l}-0.0890 \\
(0.0659)\end{array}$ \\
\hline$N$ & $5,902,373$ & $5,415,846$ & $4,799,396$ & $4,348,711$ & $4,016,151$ & $3,758,688$ & $3,552,808$ & $3,407,838$ & 3,263,343 & $3,144,516$ & 3,036,915 \\
\hline$R^{2}$ & 0.062 & 0.074 & 0.078 & 0.082 & 0.083 & 0.085 & 0.085 & 0.080 & 0.078 & 0.085 & 0.091 \\
\hline
\end{tabular}

Note: This table estimates two alternative specifications to check if the imputation is inducing a spurious correlation. Panel A replaces rank with the inverse of expected income while Panel B uses the log difference of debt as the outcome instead of the change in debt normalized by initial income. See section 3.2 in the text for details. 
APPENDIX TABLE A3: ROBUSTNESS TO GEOGRAPHIC REGION

\begin{tabular}{|c|c|c|c|c|c|c|c|c|c|c|c|}
\hline & 2002 & 2003 & 2004 & 2005 & 2006 & 2007 & 2008 & 2009 & 2010 & 2011 & 2012 \\
\hline \multirow[b]{2}{*}{$\alpha$} & \multicolumn{11}{|c|}{ Panel A: Midwest } \\
\hline & $\begin{array}{c}-1.424 * * * \\
(0.0492)\end{array}$ & $\begin{array}{c}-2.168 * * * \\
(0.0655)\end{array}$ & $\begin{array}{c}-2.911 * * * \\
(0.0914)\end{array}$ & $\begin{array}{c}-3.107 * * * \\
(0.108)\end{array}$ & $\begin{array}{c}-3.431 * * * \\
(0.129)\end{array}$ & $\begin{array}{c}-3.352 * * * \\
(0.135)\end{array}$ & $\begin{array}{c}-3.212 * * * \\
(0.134)\end{array}$ & $\begin{array}{c}-3.219 * * * \\
(0.133)\end{array}$ & $\begin{array}{c}-2.867 * * * \\
(0.125)\end{array}$ & $\begin{array}{c}-2.581 * * * \\
(0.121)\end{array}$ & $\begin{array}{c}-2.289 * * * \\
(0.111)\end{array}$ \\
\hline \multirow[t]{2}{*}{$\beta$} & $-0.316 * * *$ & $-0.388 * * *$ & $-0.512 * * *$ & $-0.482 * * *$ & $-0.486 * * *$ & $-0.434 * * *$ & $-0.365^{* * *}$ & $-0.360 * * *$ & $-0.312 * * *$ & $-0.241 * * *$ & $-0.186 * * *$ \\
\hline & $(0.0196)$ & $(0.0254)$ & $(0.0350)$ & $(0.0407)$ & $(0.0496)$ & $(0.0526)$ & $(0.0533)$ & $(0.0524)$ & $(0.0494)$ & $(0.0473)$ & (0.0439) \\
\hline \multirow[t]{2}{*}{$\gamma$} & $0.633^{* * *}$ & $0.898 * * *$ & $1.282^{* * *}$ & $1.329 * * *$ & $1.477 * * *$ & $1.376^{* * *}$ & $1.298 * * *$ & $1.305^{* * *}$ & $1.121 * * *$ & $0.977 * * *$ & $0.796 * * *$ \\
\hline & $(0.0346)$ & $(0.0463)$ & $(0.0653)$ & $(0.0770)$ & $(0.0918)$ & $(0.0965)$ & $(0.0964)$ & $(0.0951)$ & $(0.0900)$ & $(0.0866)$ & $(0.0802)$ \\
\hline$N$ & $1,308,806$ & $1,212,818$ & $1,087,589$ & 992,805 & 925,225 & 872,335 & 828,437 & 798,196 & 766,619 & 741,063 & 716,769 \\
\hline \multirow[t]{2}{*}{$R^{2}$} & 0.058 & 0.071 & 0.080 & 0.091 & 0.099 & 0.107 & 0.118 & 0.122 & 0.132 & 0.146 & 0.160 \\
\hline & \multicolumn{11}{|c|}{ Panel B: Northeast } \\
\hline$\alpha$ & $-1.340 * * *$ & $-2.191 * * *$ & $-3.168 * * *$ & $-3.593 * * *$ & $-4.230 * * *$ & $-4.440^{* * *}$ & $-4.409 * * *$ & $-4.348 * * *$ & $-4.278 * * *$ & $-3.908 * * *$ & $-3.546 * * *$ \\
\hline & $(0.0420)$ & $(0.0597)$ & $(0.0845)$ & $(0.101)$ & $(0.118)$ & $(0.130)$ & $(0.140)$ & $(0.141)$ & $(0.131)$ & $(0.123)$ & $(0.113)$ \\
\hline \multirow[t]{2}{*}{$\beta$} & $-0.288^{* * *}$ & $-0.432 * * *$ & $-0.677 * * *$ & $-0.721^{* * *}$ & $-0.860 * * *$ & $-0.908 * * *$ & $-0.891 * * *$ & $-0.880^{* * *}$ & $-0.901 * * *$ & $-0.795^{* * *}$ & $-0.724 * * *$ \\
\hline & $(0.0157)$ & $(0.0227)$ & $(0.0313)$ & $(0.0377)$ & $(0.0445)$ & $(0.0494)$ & $(0.0526)$ & $(0.0539)$ & $(0.0503)$ & $(0.0479)$ & $(0.0439)$ \\
\hline \multirow[t]{2}{*}{$\gamma$} & $0.649 * * *$ & $1.016^{* * *}$ & $1.609 * * *$ & $1.821^{* * *}$ & $2.190 * * *$ & $2.316^{* * *}$ & $2.284 * * *$ & $2.236 * * *$ & $2.224 * * *$ & $1.998 * * *$ & $1.769 * * *$ \\
\hline & $(0.0300)$ & $(0.0431)$ & $(0.0615)$ & $(0.0734)$ & $(0.0858)$ & $(0.0945)$ & $(0.102)$ & $(0.103)$ & $(0.0960)$ & $(0.0907)$ & $(0.0830)$ \\
\hline$N$ & $1,106,735$ & $1,026,724$ & 920,777 & 844,493 & 786,659 & 739,940 & 702,595 & 674,926 & 646,314 & 624,174 & 603,615 \\
\hline \multirow[t]{2}{*}{$R^{2}$} & 0.046 & 0.056 & 0.060 & 0.068 & 0.072 & 0.076 & 0.083 & 0.086 & 0.091 & 0.099 & 0.108 \\
\hline & \multicolumn{11}{|c|}{ Panel C: South } \\
\hline$\alpha$ & $-1.644 * * *$ & $-2.445^{* * *}$ & $-3.515 * * *$ & $-4.054 * * *$ & $-4.570 * * *$ & $-4.619 * * *$ & $-4.487 * * *$ & $-4.376^{* * *}$ & $-3.897 * * *$ & $-3.449 * * *$ & $-3.000 * * *$ \\
\hline & $(0.0428)$ & $(0.0647)$ & $(0.0825)$ & $(0.0995)$ & $(0.118)$ & $(0.126)$ & $(0.126)$ & $(0.128)$ & $(0.126)$ & $(0.117)$ & $(0.110)$ \\
\hline \multirow[t]{2}{*}{$\beta$} & $-0.370^{* * *}$ & $-0.453^{* * *}$ & $-0.677 * * *$ & $-0.755^{* * *}$ & $-0.859 * * *$ & $-0.802 * * *$ & $-0.740 * * *$ & $-0.721 * * *$ & $-0.607 * * *$ & $-0.511 * * *$ & $-0.401 * * *$ \\
\hline & $(0.0149)$ & $(0.0218)$ & $(0.0283)$ & $(0.0345)$ & $(0.0407)$ & $(0.0443)$ & $(0.0447)$ & $(0.0457)$ & $(0.0448)$ & $(0.0423)$ & $(0.0404)$ \\
\hline \multirow[t]{2}{*}{$\gamma$} & $0.738 * * *$ & $1.026 * * *$ & $1.608 * * *$ & $1.886 * * *$ & $2.161^{* * *}$ & $2.157 * * *$ & $2.090 * * *$ & $2.059 * * *$ & $1.811^{* * *}$ & $1.576 * * *$ & $1.314^{* * *}$ \\
\hline & $(0.0281)$ & $(0.0428)$ & $(0.0548)$ & $(0.0662)$ & $(0.0791)$ & $(0.0848)$ & $(0.0844)$ & $(0.0860)$ & $(0.0844)$ & $(0.0784)$ & $(0.0736)$ \\
\hline$N$ & $2,102,122$ & $1,929,243$ & $1,706,947$ & $1,545,476$ & $1,423,138$ & $1,328,024$ & $1,251,862$ & $1,200,950$ & $1,150,984$ & $1,107,236$ & $1,069,051$ \\
\hline \multirow[t]{2}{*}{$R^{2}$} & 0.058 & 0.073 & 0.082 & 0.091 & 0.096 & 0.101 & 0.110 & 0.114 & 0.121 & 0.133 & 0.145 \\
\hline & \multicolumn{11}{|c|}{ Panel D: West } \\
\hline$\alpha$ & $-2.053 * * *$ & $-3.262 * * *$ & $-4.642 * * *$ & $-5.396 * * *$ & $-5.951 * * *$ & $-6.233^{* * *}$ & $-6.116 * * *$ & $-6.141 * * *$ & $-5.745 * * *$ & $-5.119 * * *$ & $-4.680 * * *$ \\
\hline & $(0.0603)$ & $(0.0884)$ & $(0.111)$ & $(0.146)$ & $(0.171)$ & $(0.187)$ & $(0.183)$ & $(0.184)$ & $(0.168)$ & $(0.154)$ & $(0.134)$ \\
\hline \multirow[t]{2}{*}{$\beta$} & $-0.482 * * *$ & $-0.707 * * *$ & $-1.009 * * *$ & $-1.178 * * *$ & $-1.307^{* * *}$ & $-1.369 * * *$ & $-1.334 * * *$ & $-1.333^{* * *}$ & $-1.234 * * *$ & $-1.079 * * *$ & $-0.969 * * *$ \\
\hline & $(0.0206)$ & $(0.0290)$ & $(0.0377)$ & $(0.0485)$ & $(0.0569)$ & $(0.0638)$ & $(0.0607)$ & $(0.0618)$ & $(0.0565)$ & $(0.0518)$ & $(0.0458)$ \\
\hline \multirow[t]{2}{*}{$\gamma$} & $0.970 * * *$ & $1.500^{* * *}$ & $2.221 * * *$ & $2.630 * * *$ & $2.933^{* * *}$ & $3.101^{* * *}$ & $3.015^{* * *}$ & $3.034^{* * *}$ & $2.827 * * *$ & $2.462 * * *$ & $2.214^{* * *}$ \\
\hline & $(0.0381)$ & $(0.0563)$ & $(0.0707)$ & $(0.0939)$ & $(0.110)$ & $(0.121)$ & $(0.118)$ & $(0.118)$ & $(0.108)$ & $(0.0991)$ & $(0.0857)$ \\
\hline$N$ & $1,243,226$ & $1,118,695$ & 969,852 & 862,344 & 785,980 & 728,791 & 685,582 & 653,287 & 622,336 & 597,507 & 575,085 \\
\hline$R^{2}$ & 0.042 & 0.053 & 0.055 & 0.058 & 0.059 & 0.061 & 0.067 & 0.068 & 0.071 & 0.078 & 0.089 \\
\hline
\end{tabular}

Note: The table replicates the results in Panel A of Table 5 in the main text for each year in our sample. 
APPendiX TABle A4: Robustness to AVERAge LOCAL CREDit RATINGS

\begin{tabular}{|c|c|c|c|c|c|c|c|c|c|c|c|}
\hline & 2002 & 2003 & 2004 & 2005 & 2006 & 2007 & 2008 & 2009 & 2010 & 2011 & 2012 \\
\hline & \multicolumn{11}{|c|}{ Panel A: Low Average Credit Ratings } \\
\hline$\alpha$ & $\begin{array}{c}-1.156^{* * *} \\
(0.0397)\end{array}$ & $\begin{array}{c}-2.037 * * * \\
(0.0576)\end{array}$ & $\begin{array}{c}-3.231 * * * \\
(0.0795)\end{array}$ & $\begin{array}{c}-4.323^{* * *} \\
(0.102)\end{array}$ & $\begin{array}{c}-5.510 * * * \\
(0.129)\end{array}$ & $\begin{array}{c}-6.205^{* * *} \\
(0.146)\end{array}$ & $\begin{array}{c}-6.321 * * * \\
(0.149)\end{array}$ & $\begin{array}{c}-6.186 * * * \\
(0.149)\end{array}$ & $\begin{array}{c}-5.658 * * * \\
(0.143)\end{array}$ & $\begin{array}{c}-5.038 * * * \\
(0.134)\end{array}$ & $\begin{array}{c}-4.503^{* * *} \\
(0.128)\end{array}$ \\
\hline$\beta$ & $\begin{array}{c}-0.301 * * * \\
(0.0109)\end{array}$ & $\begin{array}{c}-0.480 * * * \\
(0.0160)\end{array}$ & $\begin{array}{c}-0.778 * * * \\
(0.0222)\end{array}$ & $\begin{array}{c}-1.018^{* * *} \\
(0.0289)\end{array}$ & $\begin{array}{c}-1.317 * * * \\
(0.0366)\end{array}$ & $\begin{array}{c}-1.476 * * * \\
(0.0418)\end{array}$ & $\begin{array}{c}-1.467 * * * \\
(0.0431)\end{array}$ & $\begin{array}{c}-1.439 * * * \\
(0.0439)\end{array}$ & $\begin{array}{c}-1.326^{* * *} \\
(0.0428)\end{array}$ & $\begin{array}{c}-1.163^{* * *} \\
(0.0406)\end{array}$ & $\begin{array}{c}-1.019 * * * \\
(0.0390)\end{array}$ \\
\hline$\gamma$ & $\begin{array}{c}0.527 * * * \\
(0.0265)\end{array}$ & $\begin{array}{c}0.930 * * * \\
(0.0386)\end{array}$ & $\begin{array}{l}1.600 * * * \\
(0.0533)\end{array}$ & $\begin{array}{c}2.241 * * * \\
(0.0691)\end{array}$ & $\begin{array}{c}2.940 * * * \\
(0.0876)\end{array}$ & $\begin{array}{c}3.375 * * * \\
(0.0994)\end{array}$ & $\begin{array}{c}3.445^{* * *} \\
(0.101)\end{array}$ & $\begin{array}{c}3.383^{* * *} \\
(0.102)\end{array}$ & $\begin{array}{c}3.109 * * * \\
(0.0974)\end{array}$ & $\begin{array}{c}2.746 * * * \\
(0.0910)\end{array}$ & $\begin{array}{c}2.415^{* * *} \\
(0.0868)\end{array}$ \\
\hline $\begin{array}{l}N \\
R^{2}\end{array}$ & $\begin{array}{c}1,811,119 \\
0.056\end{array}$ & $\begin{array}{c}1,646,108 \\
0.074 \\
\end{array}$ & $\begin{array}{c}1,417,541 \\
0.078\end{array}$ & $\begin{array}{c}1,237,579 \\
0.088 \\
\end{array}$ & $\begin{array}{c}1,104,956 \\
0.091 \\
\end{array}$ & $\begin{array}{c}999,984 \\
0.093 \\
\end{array}$ & $\begin{array}{c}917,093 \\
0.099\end{array}$ & $\begin{array}{c}864,212 \\
0.101 \\
\end{array}$ & $\begin{array}{c}812,178 \\
0.111 \\
\end{array}$ & $\begin{array}{c}763,809 \\
0.126 \\
\end{array}$ & $\begin{array}{c}724,970 \\
0.140 \\
\end{array}$ \\
\hline & \multicolumn{11}{|c|}{ Panel B: Medium Average Local Credit Ratings } \\
\hline$\alpha$ & $\begin{array}{c}-1.823 * * * \\
(0.0350)\end{array}$ & $\begin{array}{c}-2.782 * * * \\
(0.0501)\end{array}$ & $\begin{array}{c}-3.850 * * * \\
(0.0672)\end{array}$ & $\begin{array}{c}-4.408 * * * \\
(0.0821)\end{array}$ & $\begin{array}{c}-4.945^{* * *} \\
(0.0964)\end{array}$ & $\begin{array}{c}-5.130 * * * \\
(0.106)\end{array}$ & $\begin{array}{c}-5.130 * * * \\
(0.107)\end{array}$ & $\begin{array}{c}-5.097 * * * \\
(0.109)\end{array}$ & $\begin{array}{c}-4.605^{* * *} \\
(0.103)\end{array}$ & $\begin{array}{c}-4.210 * * * \\
(0.0980)\end{array}$ & $\begin{array}{c}-3.735^{* * *} \\
(0.0929)\end{array}$ \\
\hline$\beta$ & $\begin{array}{c}-0.456 * * * \\
(0.0131)\end{array}$ & $\begin{array}{c}-0.590 * * * \\
(0.0187)\end{array}$ & $\begin{array}{c}-0.836 * * * \\
(0.0252)\end{array}$ & $\begin{array}{c}-0.909 * * * \\
(0.0306)\end{array}$ & $\begin{array}{c}-1.016 * * * \\
(0.0364)\end{array}$ & $\begin{array}{c}-1.052 * * * \\
(0.0404)\end{array}$ & $\begin{array}{c}-1.035 * * * \\
(0.0410)\end{array}$ & $\begin{array}{c}-1.016^{* * *} \\
(0.0422)\end{array}$ & $\begin{array}{c}-0.891^{* * *} \\
(0.0399)\end{array}$ & $\begin{array}{c}-0.793^{* * *} \\
(0.0384)\end{array}$ & $\begin{array}{c}-0.675^{* * *} \\
(0.0361)\end{array}$ \\
\hline$\gamma$ & $\begin{array}{c}0.858 * * * \\
(0.0235)\end{array}$ & $\begin{array}{c}1.248 * * * \\
(0.0338)\end{array}$ & $\begin{array}{c}1.845^{* * *} \\
(0.0456)\end{array}$ & $\begin{array}{c}2.139 * * * \\
(0.0560)\end{array}$ & $\begin{array}{c}2.446 * * * \\
(0.0662)\end{array}$ & $\begin{array}{c}2.548 * * * \\
(0.0731)\end{array}$ & $\begin{array}{c}2.557 * * * \\
(0.0734)\end{array}$ & $\begin{array}{c}2.543^{* * *} \\
(0.0749)\end{array}$ & $\begin{array}{c}2.269 * * * \\
(0.0706)\end{array}$ & $\begin{array}{c}2.059 * * * \\
(0.0673)\end{array}$ & $\begin{array}{c}1.784^{* * *} \\
(0.0636)\end{array}$ \\
\hline $\begin{array}{l}N \\
R^{2}\end{array}$ & $\begin{array}{c}1,909,729 \\
0.056 \\
\end{array}$ & $\begin{array}{c}1,731,649 \\
0.070 \\
\end{array}$ & $\begin{array}{c}1,518,184 \\
0.082 \\
\end{array}$ & $\begin{array}{c}1,372,935 \\
0.092 \\
\end{array}$ & $\begin{array}{c}1,266,001 \\
0.098\end{array}$ & $\begin{array}{c}1,185,568 \\
0.102 \\
\end{array}$ & $\begin{array}{c}1,121,637 \\
0.111 \\
\end{array}$ & $\begin{array}{c}1,075,671 \\
0.113 \\
\end{array}$ & $\begin{array}{c}1,029,356 \\
0.118 \\
\end{array}$ & $\begin{array}{c}992,664 \\
0.128\end{array}$ & $\begin{array}{c}958,771 \\
0.137\end{array}$ \\
\hline & \multicolumn{11}{|c|}{ Panel C: High Average Local Credit Ratings } \\
\hline$\alpha$ & $\begin{array}{c}-1.209 * * * \\
(0.0312)\end{array}$ & $\begin{array}{c}-1.654 * * * \\
(0.0417)\end{array}$ & $\begin{array}{c}-2.103^{* * *} \\
(0.0523)\end{array}$ & $\begin{array}{c}-2.243^{* * *} \\
(0.0590)\end{array}$ & $\begin{array}{c}-2.415^{* * *} \\
(0.0654)\end{array}$ & $\begin{array}{c}-2.515 * * * \\
(0.0705)\end{array}$ & $\begin{array}{c}-2.449 * * * \\
(0.0698)\end{array}$ & $\begin{array}{c}-2.459 * * * \\
(0.0721)\end{array}$ & $\begin{array}{c}-2.381 * * * \\
(0.0699)\end{array}$ & $\begin{array}{c}-2.170 * * * \\
(0.0656)\end{array}$ & $\begin{array}{c}-2.063 * * * \\
(0.0610)\end{array}$ \\
\hline$\beta$ & $\begin{array}{c}-0.208^{* * *} \\
(0.0120)\end{array}$ & $\begin{array}{c}-0.195 * * * \\
(0.0165)\end{array}$ & $\begin{array}{c}-0.238 * * * \\
(0.0210)\end{array}$ & $\begin{array}{c}-0.222 * * * \\
(0.0234)\end{array}$ & $\begin{array}{c}-0.228 * * * \\
(0.0260)\end{array}$ & $\begin{array}{c}-0.218 * * * \\
(0.0286)\end{array}$ & $\begin{array}{c}-0.199 * * * \\
(0.0285)\end{array}$ & $\begin{array}{c}-0.199 * * * \\
(0.0286)\end{array}$ & $\begin{array}{c}-0.191^{* * *} \\
(0.0278)\end{array}$ & $\begin{array}{c}-0.140 * * * \\
(0.0263)\end{array}$ & $\begin{array}{c}-0.120 * * * \\
(0.0243)\end{array}$ \\
\hline$\gamma$ & $\begin{array}{c}0.503 * * * \\
(0.0212)\end{array}$ & $\begin{array}{c}0.577 * * * \\
(0.0285)\end{array}$ & $\begin{array}{c}0.831^{* * *} \\
(0.0358)\end{array}$ & $\begin{array}{c}0.888 * * * \\
(0.0404)\end{array}$ & $\begin{array}{c}0.981^{* * *} \\
(0.0451)\end{array}$ & $\begin{array}{c}1.016^{* * *} \\
(0.0486)\end{array}$ & $\begin{array}{c}0.965 * * * \\
(0.0481)\end{array}$ & $\begin{array}{c}0.960 * * * \\
(0.0497)\end{array}$ & $\begin{array}{c}0.890 * * * \\
(0.0483)\end{array}$ & $\begin{array}{c}0.740 * * * \\
(0.0452)\end{array}$ & $\begin{array}{c}0.634 * * * \\
(0.0419)\end{array}$ \\
\hline$N$ & $2,040,041$ & $1,909,723$ & $1,749,440$ & $1,634,604$ & $1,550,045$ & $1,483,538$ & $1,429,746$ & $1,387,476$ & $1,344,719$ & $1,313,507$ & $1,280,779$ \\
\hline$R^{2}$ & 0.063 & 0.075 & 0.089 & 0.094 & 0.097 & 0.101 & 0.111 & 0.113 & 0.117 & 0.125 & 0.134 \\
\hline
\end{tabular}

Note: The table replicates the results in Panel B of Table 5 in the main text for each year in our sample. 
APPENDIX TABLE A5: RoBUSTNESS tO AVERAGE INITIAL DEBT-TO-INCOME RATIOS

\begin{tabular}{|c|c|c|c|c|c|c|c|c|c|c|c|}
\hline & 2002 & 2003 & 2004 & 2005 & 2006 & 2007 & 2008 & 2009 & 2010 & 2011 & 2012 \\
\hline & \multicolumn{11}{|c|}{ Panel A: Low Average Initial Debt-to-Income Ratio } \\
\hline$\alpha$ & $\begin{array}{c}-0.995^{* * *} \\
(0.0410)\end{array}$ & $\begin{array}{c}-1.453^{* * *} \\
(0.0668)\end{array}$ & $\begin{array}{c}-2.202 * * * \\
(0.0934)\end{array}$ & $\begin{array}{c}-2.675^{* * *} \\
(0.122)\end{array}$ & $\begin{array}{c}-3.178 * * * \\
(0.148)\end{array}$ & $\begin{array}{c}-3.253 * * * \\
(0.166)\end{array}$ & $\begin{array}{c}-3.117^{* * *} \\
(0.165)\end{array}$ & $\begin{array}{c}-3.070 * * * \\
(0.163)\end{array}$ & $\begin{array}{c}-2.738^{* * *} \\
(0.165)\end{array}$ & $\begin{array}{c}-2.453^{* * *} \\
(0.152)\end{array}$ & $\begin{array}{c}-2.235^{* * * *} \\
(0.139)\end{array}$ \\
\hline$\beta$ & $\begin{array}{c}-0.234 * * * \\
(0.0147)\end{array}$ & $\begin{array}{c}-0.262 * * * \\
(0.0232)\end{array}$ & $\begin{array}{c}-0.410^{* * *} \\
(0.0326)\end{array}$ & $\begin{array}{c}-0.505^{* * *} \\
(0.0420)\end{array}$ & $\begin{array}{c}-0.619 * * * \\
(0.0522)\end{array}$ & $\begin{array}{c}-0.631 * * * \\
(0.0599)\end{array}$ & $\begin{array}{c}-0.592 * * * \\
(0.0605)\end{array}$ & $\begin{array}{c}-0.565 * * * \\
(0.0602)\end{array}$ & $\begin{array}{c}-0.503^{* * *} \\
(0.0600)\end{array}$ & $\begin{array}{c}-0.431 * * * \\
(0.0560)\end{array}$ & $\begin{array}{c}-0.378 * * * \\
(0.0523)\end{array}$ \\
\hline$\gamma$ & $\begin{array}{c}0.442^{* * *} \\
(0.0272)\end{array}$ & $\begin{array}{c}0.560 * * * \\
(0.0448)\end{array}$ & $\begin{array}{c}0.968^{* * *} \\
(0.0622)\end{array}$ & $\begin{array}{c}1.227^{* * *} \\
(0.0816)\end{array}$ & $\begin{array}{l}1.487^{* * *} \\
(0.0985)\end{array}$ & $\begin{array}{c}1.512 * * * \\
(0.111)\end{array}$ & $\begin{array}{c}1.433^{* * *} \\
(0.110)\end{array}$ & $\begin{array}{c}1.421^{* * *} \\
(0.109)\end{array}$ & $\begin{array}{c}1.268 * * * \\
(0.111)\end{array}$ & $\begin{array}{c}1.120^{* * *} \\
(0.102)\end{array}$ & $\begin{array}{r}0.994^{* * *} \\
(0.0936)\end{array}$ \\
\hline$N$ & $1,536,549$ & $1,405,965$ & $1,234,921$ & $1,113,369$ & $1,023,921$ & 951,154 & 892,311 & 853,127 & 813,229 & 779,065 & 749,549 \\
\hline$R^{2}$ & 0.045 & 0.056 & 0.059 & 0.066 & 0.068 & 0.072 & 0.080 & 0.086 & 0.096 & 0.110 & 0.125 \\
\hline \multicolumn{12}{|c|}{ Panel B: Medium Average Initial Debt-to-Income Ratio } \\
\hline$\alpha$ & $\begin{array}{c}-1.292^{* * *} \\
(0.0345)\end{array}$ & $\begin{array}{c}-1.913^{* * *} \\
(0.0502)\end{array}$ & $\begin{array}{c}-2.915^{* * *} \\
(0.0707)\end{array}$ & $\begin{array}{c}-3.489 * * * \\
(0.0862)\end{array}$ & $\begin{array}{c}-3.990 * * * \\
(0.107)\end{array}$ & $\begin{array}{c}-4.175^{* * *} \\
(0.120)\end{array}$ & $\begin{array}{c}-4.083^{* * *} \\
(0.122)\end{array}$ & $\begin{array}{c}-4.005^{* * *} \\
(0.124)\end{array}$ & $\begin{array}{c}-3.599 * * * \\
(0.115)\end{array}$ & $\begin{array}{c}-3.290 * * * \\
(0.109)\end{array}$ & $\begin{array}{c}-2.833^{* * *} \\
(0.101)\end{array}$ \\
\hline$\beta$ & $\begin{array}{c}-0.259 * * * \\
(0.0129)\end{array}$ & $\begin{array}{c}-0.310^{* * *} \\
(0.0183)\end{array}$ & $\begin{array}{c}-0.532 * * * \\
(0.0261)\end{array}$ & $\begin{array}{c}-0.632 * * * \\
(0.0320)\end{array}$ & $\begin{array}{c}-0.738 * * * \\
(0.0399)\end{array}$ & $\begin{array}{c}-0.772 * * * \\
(0.0443)\end{array}$ & $\begin{array}{c}-0.730 * * * \\
(0.0449)\end{array}$ & $\begin{array}{c}-0.716^{* * *} \\
(0.0466)\end{array}$ & $\begin{array}{c}-0.629 * * * \\
(0.0433)\end{array}$ & $\begin{array}{c}-0.556 * * * \\
(0.0411)\end{array}$ & $\begin{array}{c}-0.437 * * * \\
(0.0384)\end{array}$ \\
\hline$\gamma$ & $\begin{array}{c}0.546 * * * \\
(0.0230)\end{array}$ & $\begin{array}{c}0.721^{* * *} \\
(0.0339)\end{array}$ & $\begin{array}{c}1.267 * * * \\
(0.0476)\end{array}$ & $\begin{array}{c}1.564 * * * \\
(0.0581)\end{array}$ & $\begin{array}{l}1.841^{* * * *} \\
(0.0732)\end{array}$ & $\begin{array}{c}1.933^{* * * *} \\
(0.0819)\end{array}$ & $\begin{array}{c}1.884 * * * \\
(0.0828)\end{array}$ & $\begin{array}{c}1.849 * * * \\
(0.0844)\end{array}$ & $\begin{array}{c}1.638 * * * \\
(0.0782)\end{array}$ & $\begin{array}{c}1.485^{* * * *} \\
(0.0741)\end{array}$ & $\begin{array}{c}1.209 * * * \\
(0.0686)\end{array}$ \\
\hline$N$ & $1,945,720$ & $1,788,142$ & $1,583,443$ & $1,438,108$ & $1,328,280$ & $1,244,905$ & $1,177,341$ & $1,130,314$ & $1,083,891$ & $1,044,828$ & $1,009,820$ \\
\hline$R^{2}$ & 0.050 & 0.063 & 0.067 & 0.076 & 0.081 & 0.088 & 0.098 & 0.101 & 0.109 & 0.121 & 0.133 \\
\hline \multicolumn{12}{|c|}{ Panel C: High Average Initial Debt-to-Income Ratio } \\
\hline$\alpha$ & $\begin{array}{c}-1.654^{* * *} \\
(0.0324)\end{array}$ & $\begin{array}{c}-2.489 * * * \\
(0.0442)\end{array}$ & $\begin{array}{c}-3.413^{* * *} \\
(0.0573)\end{array}$ & $\begin{array}{c}-3.833^{* * *} \\
(0.0711)\end{array}$ & $\begin{array}{c}-4.313^{* * *} \\
(0.0838)\end{array}$ & $\begin{array}{c}-4.468 * * * \\
(0.0893)\end{array}$ & $\begin{array}{c}-4.367 * * * \\
(0.0889)\end{array}$ & $\begin{array}{c}-4.356 * * * \\
(0.0884)\end{array}$ & $\begin{array}{c}-4.026^{* * *} \\
(0.0825)\end{array}$ & $\begin{array}{c}-3.591^{* * *} \\
(0.0757)\end{array}$ & $\begin{array}{c}-3.249 * * * \\
(0.0705)\end{array}$ \\
\hline$\beta$ & $\begin{array}{c}-0.356^{* * *} \\
(0.0123)\end{array}$ & $\begin{array}{c}-0.470 * * * \\
(0.0168)\end{array}$ & $\begin{array}{c}-0.647 * * * \\
(0.0215)\end{array}$ & $\begin{array}{c}-0.705^{* * *} \\
(0.0265)\end{array}$ & $\begin{array}{c}-0.803^{* * *} \\
(0.0309)\end{array}$ & $\begin{array}{c}-0.834 * * * \\
(0.0342)\end{array}$ & $\begin{array}{c}-0.802 * * * \\
(0.0341)\end{array}$ & $\begin{array}{c}-0.790 * * * \\
(0.0341)\end{array}$ & $\begin{array}{c}-0.709 * * * \\
(0.0323)\end{array}$ & $\begin{array}{c}-0.605^{* * *} \\
(0.0300)\end{array}$ & $\begin{array}{c}-0.537 * * * \\
(0.0280)\end{array}$ \\
\hline$\gamma$ & $\begin{array}{c}0.730 * * * \\
(0.0222)\end{array}$ & $\begin{array}{c}1.030 * * * \\
(0.0304)\end{array}$ & $\begin{array}{c}1.517^{* * *} \\
(0.0393)\end{array}$ & $\begin{array}{c}1.728 * * * \\
(0.0492)\end{array}$ & $\begin{array}{l}1.995 * * * \\
(0.0581)\end{array}$ & $\begin{array}{c}2.083 * * * \\
(0.0621)\end{array}$ & $\begin{array}{c}2.012 * * * \\
(0.0618)\end{array}$ & $\begin{array}{c}2.016 * * * \\
(0.0615)\end{array}$ & $\begin{array}{l}1.829 * * * \\
(0.0573)\end{array}$ & $\begin{array}{l}1.574^{* * *} \\
(0.0526)\end{array}$ & $\begin{array}{l}1.374 * * * \\
(0.0488)\end{array}$ \\
\hline$N$ & $2,278,620$ & 2,093,373 & $1,866,801$ & $1,693,641$ & $1,568,801$ & $1,473,031$ & $1,398,824$ & $1,343,918$ & $1,289,133$ & $1,246,087$ & $1,205,151$ \\
\hline$R^{2}$ & 0.058 & 0.071 & 0.079 & 0.086 & 0.092 & 0.100 & 0.109 & 0.112 & 0.115 & 0.122 & 0.131 \\
\hline
\end{tabular}

Note: The table replicates the results in Panel C of Table 5 in the main text for each year in our sample. 
ApPendiX TABLE A6: RoBUstness to AVERAGE HOUSE PRICE GROWTH (2001-2005)

\begin{tabular}{|c|c|c|c|c|c|c|c|c|c|c|c|}
\hline & 2002 & 2003 & 2004 & 2005 & 2006 & 2007 & 2008 & 2009 & 2010 & 2011 & 2012 \\
\hline \multirow[b]{2}{*}{$\alpha$} & \multicolumn{11}{|c|}{ Panel A: Low Average House Price Growth } \\
\hline & $\begin{array}{l}-1.703 * * * \\
(0.0495)\end{array}$ & $\begin{array}{l}-2.689 * * * \\
(0.0688)\end{array}$ & $\begin{array}{l}-3.509 * * * \\
(0.0940)\end{array}$ & $\begin{array}{l}-3.745 * * * \\
(0.108)\end{array}$ & $\begin{array}{l}-3.965 * * * \\
(0.129)\end{array}$ & $\begin{array}{l}-3.872 * * * \\
(0.135)\end{array}$ & $\begin{array}{l}-4.611 * * * \\
(0.147)\end{array}$ & $\begin{array}{l}-5.124 * * * \\
(0.149)\end{array}$ & $\begin{array}{l}-4.311 * * * \\
(0.138)\end{array}$ & $\begin{array}{l}-3.800^{* * * *} \\
(0.127)\end{array}$ & $\begin{array}{l}-3.184 * * * \\
(0.118)\end{array}$ \\
\hline \multirow[t]{2}{*}{$\beta$} & $-0.388 * * *$ & $-0.527 * * *$ & $-0.668 * * *$ & $-0.640 * * *$ & $-0.633^{* * *}$ & $-0.577 * * *$ & $-0.788^{* * *}$ & $-0.975^{* * *}$ & $-0.746^{* * *}$ & $-0.613^{* * *}$ & $-0.460 * * *$ \\
\hline & $(0.0181)$ & $(0.0244)$ & $(0.0347)$ & $(0.0399)$ & $(0.0471)$ & $(0.0510)$ & $(0.0553)$ & $(0.0577)$ & $(0.0523)$ & $(0.0474)$ & $(0.0461)$ \\
\hline \multirow[t]{2}{*}{$\gamma$} & $0.778 * * *$ & $1.195^{* * *}$ & $1.608 * * *$ & $1.690 * * *$ & $1.773 * * *$ & $1.677 * * *$ & $2.215^{* * *}$ & $2.552 * * *$ & $2.055^{* * *}$ & $1.763^{* * *}$ & $1.379 * * *$ \\
\hline & $(0.0331)$ & $(0.0463)$ & (0.0639) & $(0.0743)$ & (0.0889) & $(0.0941)$ & $(0.103)$ & $(0.103)$ & $(0.0955)$ & $(0.0879)$ & $(0.0818)$ \\
\hline$N$ & $1,291,537$ & $1,189,220$ & $1,049,983$ & 956,487 & 888,735 & 836,451 & 782,371 & 733,143 & 697,338 & 672,647 & 658,245 \\
\hline \multirow[t]{2}{*}{$R^{2}$} & 0.059 & 0.074 & 0.090 & 0.103 & 0.108 & 0.114 & 0.119 & 0.117 & 0.125 & 0.134 & 0.148 \\
\hline & \multicolumn{11}{|c|}{ Panel B: Medium Average House Price Growth } \\
\hline$\alpha$ & $-1.748 * * *$ & $-2.605 * * *$ & $-3.532 * * *$ & $-3.894 * * *$ & $-4.612^{* * *}$ & $-5.136 * * *$ & $-4.832 * * *$ & $-4.470 * * *$ & $-4.317 * * *$ & $-3.855^{* * *}$ & $-3.553 * * *$ \\
\hline & $(0.0448)$ & $(0.0666)$ & $(0.0826)$ & $(0.0983)$ & $(0.121)$ & $(0.134)$ & $(0.145)$ & $(0.142)$ & $(0.136)$ & $(0.127)$ & $(0.116)$ \\
\hline \multirow[t]{2}{*}{$\beta$} & $-0.416 * * *$ & $-0.527 * * *$ & $-0.686 * * *$ & $-0.718 * * *$ & $-0.865^{* * *}$ & $-1.024 * * *$ & $-0.915^{* * *}$ & $-0.778 * * *$ & $-0.778 * * *$ & $-0.652 * * *$ & $-0.613^{* * *}$ \\
\hline & $(0.0174)$ & $(0.0254)$ & $(0.0313)$ & $(0.0368)$ & $(0.0457)$ & $(0.0501)$ & $(0.0554)$ & $(0.0531)$ & $(0.0508)$ & $(0.0485)$ & $(0.0445)$ \\
\hline \multirow[t]{2}{*}{$\gamma$} & $0.851 * * *$ & $1.191^{* * *}$ & $1.688 * * *$ & $1.867^{* * *}$ & $2.281^{* * *}$ & $2.603 * * *$ & $2.368 * * *$ & $2.132 * * *$ & $2.070^{* * *}$ & $1.795^{* * *}$ & $1.643^{* * *}$ \\
\hline & $(0.0300)$ & $(0.0454)$ & $(0.0564)$ & $(0.0682)$ & $(0.0839)$ & $(0.0919)$ & $(0.0987)$ & $(0.0964)$ & $(0.0923)$ & $(0.0863)$ & $(0.0787)$ \\
\hline$N$ & $1,314,237$ & $1,194,454$ & $1,059,984$ & 971,383 & 899,143 & 820,675 & 755,509 & 730,221 & 702,186 & 674,141 & 655,088 \\
\hline \multirow[t]{2}{*}{$R^{2}$} & 0.054 & 0.067 & 0.069 & 0.073 & 0.077 & 0.083 & 0.099 & 0.104 & 0.109 & 0.119 & 0.127 \\
\hline & \multicolumn{11}{|c|}{ Panel C: High Average House Price Growth } \\
\hline$\alpha$ & $-1.643 * * *$ & $-2.504 * * *$ & $-3.838 * * *$ & $-5.022 * * *$ & $-5.690 * * *$ & $-5.650 * * *$ & $-5.236 * * *$ & $-5.035 * * *$ & $-4.649 * * *$ & $-4.289 * * *$ & $-3.810 * * *$ \\
\hline & $(0.0450)$ & $(0.0663)$ & $(0.0947)$ & $(0.136)$ & $(0.164)$ & $(0.179)$ & $(0.155)$ & $(0.143)$ & $(0.139)$ & $(0.126)$ & $(0.116)$ \\
\hline$\beta$ & $-0.357 * * *$ & $-0.484 * * *$ & $-0.797 * * *$ & $-1.077 * * *$ & $-1.259 * * *$ & $-1.206 * * *$ & $-1.107 * * *$ & $-1.038 * * *$ & $-0.959 * * *$ & $-0.864 * * *$ & $-0.704 * * *$ \\
\hline & $(0.0161)$ & $(0.0235)$ & $(0.0333)$ & $(0.0466)$ & $(0.0559)$ & $(0.0614)$ & $(0.0534)$ & $(0.0508)$ & $(0.0489)$ & $(0.0450)$ & $(0.0417)$ \\
\hline$\gamma$ & $0.745^{* * *}$ & $1.065^{* * *}$ & $1.810 * * *$ & $2.480 * * *$ & $2.864 * * *$ & $2.828 * * *$ & $2.607 * * *$ & $2.522 * * *$ & $2.314 * * *$ & $2.130 * * *$ & $1.803^{* * *}$ \\
\hline & $(0.0295)$ & $(0.0436)$ & $(0.0621)$ & $(0.0890)$ & $(0.108)$ & $(0.119)$ & $(0.103)$ & $(0.0964)$ & $(0.0940)$ & $(0.0850)$ & $(0.0777)$ \\
\hline$N$ & $1,368,563$ & $1,240,625$ & $1,075,547$ & 937,809 & 846,694 & 799,557 & 779,330 & 754,477 & 719,891 & 692,720 & 653,636 \\
\hline$R^{2}$ & 0.046 & 0.054 & 0.054 & 0.057 & 0.056 & 0.061 & 0.070 & 0.077 & 0.080 & 0.089 & 0.098 \\
\hline
\end{tabular}

Note: The table replicates the results in Panel D of Table 5 in the main text for each year in our sample. 
APPENDIX TABle A7: RoBUSTNESS TO INITIAL LEVELS OF HOUSE PRICES RELATIVE TO INCOME

\begin{tabular}{|c|c|c|c|c|c|c|c|c|c|c|c|}
\hline & 2002 & 2003 & 2004 & 2005 & 2006 & 2007 & 2008 & 2009 & 2010 & 2011 & 2012 \\
\hline & \multicolumn{11}{|c|}{ Panel A: Low Initial Relative House Prices } \\
\hline$\alpha$ & $\begin{array}{l}-1.417 * * * \\
(0.042)\end{array}$ & $\begin{array}{l}-2.150 * * * \\
(0.063)\end{array}$ & $\begin{array}{l}-3.125 * * * \\
(0.084)\end{array}$ & $\begin{array}{l}-3.728 * * * \\
(0.104)\end{array}$ & $\begin{array}{l}-4.367 * * * \\
(0.124)\end{array}$ & $\begin{array}{l}-4.707 * * * \\
(0.144)\end{array}$ & $\begin{array}{l}-4.714 * * * \\
(0.143)\end{array}$ & $\begin{array}{l}-4.722 * * * \\
(0.140)\end{array}$ & $\begin{array}{l}-4.351 * * * \\
(0.133)\end{array}$ & $\begin{array}{l}-3.949 * * * \\
(0.125)\end{array}$ & $\begin{array}{l}-3.569 * * * \\
(0.113)\end{array}$ \\
\hline$\beta$ & $\begin{array}{l}-0.303^{* * *} \\
(0.014)\end{array}$ & $\begin{array}{l}-0.399 * * * \\
(0.021)\end{array}$ & $\begin{array}{l}-0.572 * * * \\
(0.029)\end{array}$ & $\begin{array}{l}-0.697 * * * \\
(0.036)\end{array}$ & $\begin{array}{l}-0.829 * * * \\
(0.043)\end{array}$ & $\begin{array}{l}-0.915 * * * \\
(0.050)\end{array}$ & $\begin{array}{l}-0.914 * * * \\
(0.049)\end{array}$ & $\begin{array}{l}-0.893 * * * \\
(0.049)\end{array}$ & $\begin{array}{l}-0.811^{* * *} \\
(0.046)\end{array}$ & $\begin{array}{l}-0.728 * * * \\
(0.043)\end{array}$ & $\begin{array}{l}-0.632^{* * *} \\
(0.040)\end{array}$ \\
\hline$\gamma$ & $\begin{array}{l}0.624^{* * *} \\
(0.026)\end{array}$ & $\begin{array}{l}0.872 * * * \\
(0.040)\end{array}$ & $\begin{array}{l}1.363 * * * \\
(0.053)\end{array}$ & $\begin{array}{l}1.682 * * * \\
(0.066)\end{array}$ & $\begin{array}{l}2.037 * * * \\
(0.080)\end{array}$ & $\begin{array}{l}2.232^{* * *} \\
(0.093)\end{array}$ & $\begin{array}{l}2.231^{* * *} \\
(0.092)\end{array}$ & $\begin{array}{l}2.224 * * * \\
(0.091)\end{array}$ & $\begin{array}{l}2.022 * * * \\
(0.086)\end{array}$ & $\begin{array}{l}1.794 * * * \\
(0.080)\end{array}$ & $\begin{array}{l}1.560^{* * *} \\
(0.072)\end{array}$ \\
\hline $\begin{array}{l}N \\
R^{2} \\
\end{array}$ & $\begin{array}{c}1,346,793 \\
0.036 \\
\end{array}$ & $\begin{array}{c}1,210,187 \\
0.043 \\
\end{array}$ & $\begin{array}{c}1,047,956 \\
0.043 \\
\end{array}$ & $\begin{array}{c}935,253 \\
0.045 \\
\end{array}$ & $\begin{array}{c}855,929 \\
0.047 \\
\end{array}$ & $\begin{array}{c}795,208 \\
0.051 \\
\end{array}$ & $\begin{array}{c}748,478 \\
0.058 \\
\end{array}$ & $\begin{array}{c}712,722 \\
0.061 \\
\end{array}$ & $\begin{array}{c}677,495 \\
0.064 \\
\end{array}$ & $\begin{array}{c}650,400 \\
0.071 \\
\end{array}$ & $\begin{array}{c}624,841 \\
0.081 \\
\end{array}$ \\
\hline \multicolumn{12}{|c|}{ Panel B: Medium Initial Relative House Prices } \\
\hline$\alpha$ & $\begin{array}{l}-1.595 * * * \\
(0.051)\end{array}$ & $\begin{array}{l}-2.489 * * * \\
(0.073)\end{array}$ & $\begin{array}{l}-3.304 * * * \\
(0.099)\end{array}$ & $\begin{array}{l}-3.689 * * * \\
(0.120)\end{array}$ & $\begin{array}{l}-4.152 * * * \\
(0.139)\end{array}$ & $\begin{array}{l}-4.256^{* * *} \\
(0.150)\end{array}$ & $\begin{array}{l}-4.190 * * * \\
(0.149)\end{array}$ & $\begin{array}{l}-4.054 * * * \\
(0.153)\end{array}$ & $\begin{array}{l}-3.723 * * * \\
(0.142)\end{array}$ & $\begin{array}{l}-3.283 * * * \\
(0.132)\end{array}$ & $\begin{array}{l}-2.991 * * * \\
(0.124)\end{array}$ \\
\hline$\beta$ & $\begin{array}{l}-0.330 * * * \\
(0.020)\end{array}$ & $\begin{array}{l}-0.441 * * * \\
(0.028)\end{array}$ & $\begin{array}{l}-0.607 * * * \\
(0.038)\end{array}$ & $\begin{array}{l}-0.627 * * * \\
(0.045)\end{array}$ & $\begin{array}{l}-0.724 * * * \\
(0.053)\end{array}$ & $\begin{array}{l}-0.728 * * * \\
(0.057)\end{array}$ & $\begin{array}{l}-0.676^{* * *} \\
(0.057)\end{array}$ & $\begin{array}{l}-0.613^{* * *} \\
(0.059)\end{array}$ & $\begin{array}{l}-0.548^{* * *} \\
(0.056)\end{array}$ & $\begin{array}{l}-0.451 * * * \\
(0.052)\end{array}$ & $\begin{array}{l}-0.406^{* * *} \\
(0.049)\end{array}$ \\
\hline$\gamma$ & $\begin{array}{l}0.670 * * * \\
(0.035)\end{array}$ & $\begin{array}{l}0.999 * * * \\
(0.050)\end{array}$ & $\begin{array}{l}1.402 * * * \\
(0.068)\end{array}$ & $\begin{array}{l}1.557 * * * \\
(0.082)\end{array}$ & $\begin{array}{l}1.802 * * * \\
(0.095)\end{array}$ & $\begin{array}{l}1.847 * * * \\
(0.103)\end{array}$ & $\begin{array}{l}1.811^{* * *} \\
(0.102)\end{array}$ & $\begin{array}{l}1.737 * * * \\
(0.106)\end{array}$ & $\begin{array}{l}1.571^{* * * *} \\
(0.098)\end{array}$ & $\begin{array}{l}1.327 * * * \\
(0.092)\end{array}$ & $\begin{array}{l}1.176^{* * *} \\
(0.086)\end{array}$ \\
\hline$N$ & $1,333,467$ & $1,220,350$ & $1,076,042$ & 968,303 & 890,466 & 830,645 & 783,737 & 751,365 & 719,215 & 692,286 & 668,525 \\
\hline$R^{2}$ & 0.062 & 0.076 & 0.084 & 0.092 & 0.096 & 0.103 & 0.113 & 0.116 & 0.122 & 0.132 & 0.142 \\
\hline \multicolumn{12}{|c|}{ Panel C: High Initial Relative House Prices } \\
\hline$\alpha$ & $\begin{array}{l}-1.419 * * * \\
(0.056)\end{array}$ & $\begin{array}{l}-2.161 * * * \\
(0.076)\end{array}$ & $\begin{array}{l}-3.015^{* * *} \\
(0.099)\end{array}$ & $\begin{array}{l}-3.381 * * * \\
(0.120)\end{array}$ & $\begin{array}{l}-3.641 * * * \\
(0.146)\end{array}$ & $\begin{array}{l}-3.702 * * * \\
(0.151)\end{array}$ & $\begin{array}{l}-3.485^{* * *} \\
(0.157)\end{array}$ & $\begin{array}{l}-3.538 * * * \\
(0.152)\end{array}$ & $\begin{array}{l}-3.291 * * * \\
(0.146)\end{array}$ & $\begin{array}{l}-2.890 * * * \\
(0.130)\end{array}$ & $\begin{array}{l}-2.515^{* * *} \\
(0.119)\end{array}$ \\
\hline$\beta$ & $\begin{array}{l}-0.293 * * * \\
(0.021)\end{array}$ & $\begin{array}{l}-0.376^{* * *} \\
(0.028)\end{array}$ & $\begin{array}{l}-0.544 * * * \\
(0.037)\end{array}$ & $\begin{array}{l}-0.585 * * * \\
(0.045)\end{array}$ & $\begin{array}{l}-0.591 * * * \\
(0.056)\end{array}$ & $\begin{array}{l}-0.566 * * * \\
(0.059)\end{array}$ & $\begin{array}{l}-0.481 * * * \\
(0.061)\end{array}$ & $\begin{array}{l}-0.524 * * * \\
(0.060)\end{array}$ & $\begin{array}{l}-0.506 * * * \\
(0.057)\end{array}$ & $\begin{array}{l}-0.417 * * * \\
(0.052)\end{array}$ & $\begin{array}{l}-0.310^{* * *} \\
(0.047)\end{array}$ \\
\hline$\gamma$ & $\begin{array}{l}0.596 * * * \\
(0.039)\end{array}$ & $\begin{array}{l}0.858^{* * *} \\
(0.053)\end{array}$ & $\begin{array}{l}1.308^{* * *} \\
(0.069)\end{array}$ & $\begin{array}{l}1.480 * * * \\
(0.084)\end{array}$ & $\begin{array}{l}1.577^{* * *} \\
(0.102)\end{array}$ & $\begin{array}{l}1.585^{* * *} \\
(0.106)\end{array}$ & $\begin{array}{l}1.445^{* * *} \\
(0.110)\end{array}$ & $\begin{array}{l}1.509^{* * *} \\
(0.107)\end{array}$ & $\begin{array}{l}1.416^{* * *} \\
(0.103)\end{array}$ & $\begin{array}{l}1.208^{* * *} \\
(0.091)\end{array}$ & $\begin{array}{l}0.993^{* * *} \\
(0.084)\end{array}$ \\
\hline$N$ & $1,299,320$ & $1,198,652$ & $1,065,879$ & 966,058 & 891,869 & 834,311 & 788,325 & 756,972 & 725,798 & 699,816 & 676,498 \\
\hline$R^{2}$ & 0.065 & 0.082 & 0.091 & 0.104 & 0.109 & 0.115 & 0.126 & 0.129 & 0.136 & 0.149 & 0.162 \\
\hline
\end{tabular}

Note: The table replicates the results in Panel E of Table 5 in the main text for each year in our sample. 
APPENDIX TABLE A8

\begin{tabular}{|c|c|c|c|c|c|c|c|c|c|c|c|}
\hline & 2002 & 2003 & 2004 & 2005 & 2006 & 2007 & 2008 & 2009 & 2010 & 2011 & 2012 \\
\hline \multirow[b]{2}{*}{$\alpha$} & \multicolumn{11}{|c|}{ Panel A: Households with No Mortgage Debt in 2001} \\
\hline & $\begin{array}{l}-0.934 * * * \\
(0.032)\end{array}$ & $\begin{array}{l}-1.897 * * * \\
(0.041)\end{array}$ & $\begin{array}{l}-3.120 * * * \\
(0.055)\end{array}$ & $\begin{array}{l}-3.780 * * * \\
(0.069)\end{array}$ & $\begin{array}{l}-4.622 * * * \\
(0.083)\end{array}$ & $\begin{array}{l}-4.915 * * * \\
(0.091)\end{array}$ & $\begin{array}{l}-4.832 * * * \\
(0.091)\end{array}$ & $\begin{array}{l}-4.786 * * * \\
(0.093)\end{array}$ & $\begin{array}{l}-4.314 * * * \\
(0.088)\end{array}$ & $\begin{array}{l}-3.987 * * * \\
(0.084)\end{array}$ & $\begin{array}{l}-3.562 * * * \\
(0.079)\end{array}$ \\
\hline$\beta$ & $\begin{array}{l}-0.297 * * * \\
(0.009)\end{array}$ & $\begin{array}{l}-0.449 * * * \\
(0.013)\end{array}$ & $\begin{array}{l}-0.713 * * * \\
(0.017)\end{array}$ & $\begin{array}{l}-0.818 * * * \\
(0.022)\end{array}$ & $\begin{array}{l}-0.972 * * * \\
(0.026)\end{array}$ & $\begin{array}{l}-1.009 * * * \\
(0.029)\end{array}$ & $\begin{array}{l}-0.971 * * * \\
(0.030)\end{array}$ & $\begin{array}{l}-0.969 * * * \\
(0.030)\end{array}$ & $\begin{array}{l}-0.897 * * * \\
(0.028)\end{array}$ & $\begin{array}{l}-0.814 * * * \\
(0.027)\end{array}$ & $\begin{array}{l}-0.725 * * * \\
(0.026)\end{array}$ \\
\hline$\gamma$ & $\begin{array}{l}0.431 * * * \\
(0.022)\end{array}$ & $\begin{array}{l}0.835 * * * \\
(0.028)\end{array}$ & $\begin{array}{l}1.472^{* * *} \\
(0.038)\end{array}$ & $\begin{array}{l}1.815 * * * \\
(0.047)\end{array}$ & $\begin{array}{l}2.258 * * * \\
(0.056)\end{array}$ & $\begin{array}{l}2.409 * * * \\
(0.062)\end{array}$ & $\begin{array}{l}2.372 * * * \\
(0.062)\end{array}$ & $\begin{array}{l}2.393 * * * \\
(0.064)\end{array}$ & $\begin{array}{l}2.169 * * * \\
(0.060)\end{array}$ & $\begin{array}{l}2.033 * * * \\
(0.057)\end{array}$ & $\begin{array}{l}1.813^{* * *} \\
(0.054)\end{array}$ \\
\hline$N$ & $2,748,810$ & $2,482,153$ & $2,149,720$ & $1,912,682$ & $1,743,540$ & $1,609,502$ & $1,500,510$ & $1,425,800$ & $1,351,290$ & $1,289,411$ & $1,236,456$ \\
\hline \multirow[t]{2}{*}{$R^{2}$} & 0.035 & 0.048 & 0.062 & 0.068 & 0.074 & 0.077 & 0.082 & 0.083 & 0.084 & 0.085 & 0.085 \\
\hline & \multicolumn{11}{|c|}{ Panel B: Households with Positive Mortgage Debt in 2001} \\
\hline$\alpha$ & $\begin{array}{l}-0.994 * * * \\
(0.031)\end{array}$ & $\begin{array}{l}-1.422 * * * \\
(0.043)\end{array}$ & $\begin{array}{l}-1.758^{* * *} \\
(0.053)\end{array}$ & $\begin{array}{l}-1.951 * * * \\
(0.062)\end{array}$ & $\begin{array}{l}-2.144 * * * \\
(0.070)\end{array}$ & $\begin{array}{l}-2.215^{* * *} \\
(0.076)\end{array}$ & $\begin{array}{l}-2.223 * * * \\
(0.078)\end{array}$ & $\begin{array}{l}-2.264 * * * \\
(0.080)\end{array}$ & $\begin{array}{l}-2.117 * * * \\
(0.078)\end{array}$ & $\begin{array}{l}-1.853 * * * \\
(0.073)\end{array}$ & $\begin{array}{l}-1.696 * * * \\
(0.068)\end{array}$ \\
\hline$\beta$ & $\begin{array}{l}-0.088^{* * *} \\
(0.013)\end{array}$ & $\begin{array}{l}-0.074^{* * *} \\
(0.018)\end{array}$ & $\begin{array}{l}-0.037 * \\
(0.022)\end{array}$ & $\begin{array}{l}-0.030 \\
(0.025)\end{array}$ & $\begin{array}{l}-0.046 \\
(0.029)\end{array}$ & $\begin{array}{l}-0.062 * \\
(0.032)\end{array}$ & $\begin{array}{l}-0.083^{* *} \\
(0.032)\end{array}$ & $\begin{array}{l}-0.100^{* * *} \\
(0.033)\end{array}$ & $\begin{array}{l}-0.109 * * * \\
(0.032)\end{array}$ & $\begin{array}{l}-0.088^{* * *} \\
(0.031)\end{array}$ & $\begin{array}{l}-0.104^{* * *} \\
(0.028)\end{array}$ \\
\hline$\gamma$ & $\begin{array}{l}0.288^{* * *} \\
(0.022)\end{array}$ & $\begin{array}{l}0.360 * * * \\
(0.030)\end{array}$ & $\begin{array}{l}0.438 * * * \\
(0.036)\end{array}$ & $\begin{array}{l}0.516^{* * *} \\
(0.043)\end{array}$ & $\begin{array}{l}0.594 * * * \\
(0.049)\end{array}$ & $\begin{array}{l}0.643 * * * \\
(0.053)\end{array}$ & $\begin{array}{l}0.690 * * * \\
(0.054)\end{array}$ & $\begin{array}{l}0.744 * * * \\
(0.055)\end{array}$ & $\begin{array}{l}0.759 * * * \\
(0.054)\end{array}$ & $\begin{array}{l}0.680^{* * *} \\
(0.051)\end{array}$ & $\begin{array}{l}0.662 * * * \\
(0.047)\end{array}$ \\
\hline$N$ & $3,012,079$ & $2,805,327$ & $2,535,445$ & $2,332,436$ & $2,177,462$ & $2,059,588$ & $1,967,966$ & $1,901,559$ & $1,834,963$ & $1,780,569$ & $1,728,064$ \\
\hline$R^{2}$ & 0.040 & 0.046 & 0.061 & 0.066 & 0.072 & 0.077 & 0.081 & 0.081 & 0.076 & 0.076 & 0.075 \\
\hline
\end{tabular}

Note: This table presents results from estimating the same specification as in Panel C of Table 3 for two subsets of the data: households with no mortgage debt in 2001 (Panel A) and households with positive mortgage debt in 2001 (Panel B). 
APPENDIX TABLE A9-1: ROBUSTNESS TO ADDITIONAL INTERACTIONS

\begin{tabular}{|c|c|c|c|c|c|c|c|c|c|c|c|}
\hline & 2002 & 2003 & 2004 & 2005 & 2006 & 2007 & 2008 & 2009 & 2010 & 2011 & 2012 \\
\hline \multirow{3}{*}{$\alpha$} & \multicolumn{11}{|c|}{ Panel A: Includes Interaction of Rank with Rate of Homeownership } \\
\hline & $-0.980 * * *$ & $-1.368 * * *$ & $-1.767 * * *$ & $-1.951^{* * *}$ & $-2.115^{* * *}$ & $-2.107 * * *$ & $-2.005^{* * *}$ & $-2.095 * * *$ & $-1.885 * * *$ & $-1.692 * * *$ & $-1.552 * * *$ \\
\hline & $(0.0249)$ & $(0.0356)$ & $(0.0462)$ & $(0.0578)$ & $(0.0694)$ & $(0.0762)$ & $(0.0771)$ & $(0.0769)$ & $(0.0733)$ & $(0.0682)$ & $(0.0643)$ \\
\hline \multirow[t]{2}{*}{$\beta$} & $-0.259 * * *$ & $-0.311 * * *$ & $-0.406 * * *$ & $-0.434 * * *$ & $-0.487 * * *$ & $-0.486 * * *$ & $-0.442 * * *$ & $-0.444 * * *$ & $-0.385 * * *$ & $-0.317 * * *$ & $-0.272 * * *$ \\
\hline & (0.00819) & $(0.0118)$ & $(0.0155)$ & $(0.0190)$ & $(0.0228)$ & $(0.0255)$ & $(0.0256)$ & $(0.0258)$ & $(0.0243)$ & $(0.0226)$ & $(0.0211)$ \\
\hline \multirow{2}{*}{$\gamma$} & $0.516 * * *$ & $0.683 * * *$ & $1.022^{* * *}$ & $1.186 * * *$ & $1.364 * * *$ & $1.403 * * *$ & $1.337 * * *$ & $1.360 * * *$ & $1.214^{* * *}$ & $1.056 * * *$ & $0.906 * * *$ \\
\hline & $(0.0143)$ & $(0.0205)$ & $(0.0264)$ & $(0.0330)$ & $(0.0396)$ & $(0.0435)$ & $(0.0435)$ & $(0.0439)$ & $(0.0416)$ & $(0.0383)$ & $(0.0359)$ \\
\hline$N$ & $5,727,356$ & $5,257,066$ & $4,658,759$ & $4,221,379$ & $3,899,085$ & $3,648,535$ & $3,449,008$ & $3,308,587$ & $3,168,380$ & $3,052,691$ & $2,947,893$ \\
\hline \multirow[t]{2}{*}{$R^{2}$} & 0.051 & 0.063 & 0.070 & 0.078 & 0.083 & 0.088 & 0.097 & 0.100 & 0.106 & 0.116 & 0.126 \\
\hline & \multicolumn{11}{|c|}{ Panel B: Includes Interaction of Rank with Fraction of Black Residents } \\
\hline$\alpha$ & $-1.514 * * *$ & $-2.294 * * *$ & $-3.284 * * *$ & $-3.795 * * *$ & $-4.335^{* * *}$ & $-4.514 * * *$ & $-4.405^{* * *}$ & $-4.366^{* * *}$ & $-3.995 * * *$ & $-3.586 * * *$ & $-3.197 * * *$ \\
\hline & $(0.0220)$ & $(0.0316)$ & $(0.0418)$ & $(0.0518)$ & $(0.0615)$ & $(0.0670)$ & $(0.0668)$ & $(0.0666)$ & $(0.0630)$ & $(0.0584)$ & $(0.0538)$ \\
\hline \multirow[t]{2}{*}{$\beta$} & $-0.374 * * *$ & $-0.474 * * *$ & $-0.704 * * *$ & $-0.794 * * *$ & $-0.915 * * *$ & $-0.948 * * *$ & $-0.901 * * *$ & $-0.881 * * *$ & $-0.786 * * *$ & $-0.677 * * *$ & $-0.578 * * *$ \\
\hline & $(0.00863)$ & (0.0119) & $(0.0164)$ & $(0.0201)$ & $(0.0239)$ & $(0.0264)$ & $(0.0264)$ & $(0.0263)$ & $(0.0247)$ & $(0.0229)$ & $(0.0210)$ \\
\hline \multirow{2}{*}{$\gamma$} & $0.660 * * *$ & $0.943 * * *$ & $1.448 * * *$ & $1.709 * * *$ & $1.992 * * *$ & $2.081 * * *$ & $2.011 * * *$ & $1.994 * * *$ & $1.801 * * *$ & $1.582 * * *$ & $1.363 * * *$ \\
\hline & $(0.0147)$ & $(0.0213)$ & $(0.0283)$ & $(0.0353)$ & $(0.0421)$ & $(0.0460)$ & $(0.0457)$ & $(0.0456)$ & $(0.0432)$ & $(0.0400)$ & $(0.0367)$ \\
\hline$N$ & $5,727,471$ & $5,257,165$ & $4,658,826$ & $4,221,433$ & 3,899,132 & $3,648,580$ & $3,449,048$ & 3,308,627 & $3,168,414$ & $3,052,725$ & $2,947,921$ \\
\hline$R^{2}$ & 0.050 & 0.063 & 0.069 & 0.076 & 0.081 & 0.086 & 0.095 & 0.098 & 0.104 & 0.114 & 0.125 \\
\hline
\end{tabular}

Note: This table augments the specification in Panel C of Table 3 of the main text by adding the level of the listed variable and its interaction with rank. Panel A includes the fraction of residents in a zipcode who own their home calculated from the Census. Panel B includes the fraction of residents who identify as black calculated from the Census. 
APPENDIX TABLE A9-2: ROBUSTNESS TO ADDITIONAL INTERACTIONS

\begin{tabular}{|c|c|c|c|c|c|c|c|c|c|c|c|}
\hline & 2002 & 2003 & 2004 & 2005 & 2006 & 2007 & 2008 & 2009 & 2010 & 2011 & 2012 \\
\hline & \multicolumn{11}{|c|}{ Panel C: Includes Interaction of Rank with House Quality Dispersion } \\
\hline \multirow[t]{2}{*}{$\alpha$} & $-1.617^{* * *}$ & $-2.488 * * *$ & $-3.554 * * *$ & $-4.125^{* * *}$ & $-4.777 * * *$ & $-4.982 * * *$ & $-4.888 * * *$ & $-4.828 * * *$ & $-4.429 * * *$ & $-3.972 * * *$ & $-3.544 * * *$ \\
\hline & $(0.0285)$ & $(0.0420)$ & $(0.0564)$ & $(0.0697)$ & $(0.0831)$ & $(0.0905)$ & $(0.0909)$ & $(0.0910)$ & $(0.0871)$ & $(0.0803)$ & $(0.0742)$ \\
\hline \multirow[t]{2}{*}{$\beta$} & $-0.395 * * *$ & $-0.485 * * *$ & $-0.762 * * *$ & $-0.861 * * *$ & $-1.004 * * *$ & $-1.053 * * *$ & $-1.021 * * *$ & $-0.978 * * *$ & $-0.864 * * *$ & $-0.748 * * *$ & $-0.645 * * *$ \\
\hline & $(0.0117)$ & $(0.0167)$ & $(0.0230)$ & $(0.0283)$ & $(0.0347)$ & $(0.0382)$ & $(0.0381)$ & $(0.0383)$ & (0.0359) & $(0.0334)$ & $(0.0306)$ \\
\hline \multirow[t]{2}{*}{$\gamma$} & $0.727 * * *$ & $1.016 * * *$ & $1.570 * * *$ & $1.843^{* * *}$ & $2.162 * * *$ & $2.278 * * *$ & $2.219 * * *$ & $2.155 * * *$ & $1.943 * * *$ & $1.708 * * *$ & $1.493 * * *$ \\
\hline & $(0.0196)$ & $(0.0294)$ & $(0.0398)$ & (0.0499) & $(0.0600)$ & $(0.0662)$ & $(0.0668)$ & $(0.0667)$ & $(0.0633)$ & $(0.0585)$ & $(0.0539)$ \\
\hline$N$ & $3,134,287$ & $2,866,480$ & 2,531,193 & $2,286,429$ & 2,109,396 & $1,974,580$ & $1,867,883$ & $1,791,116$ & $1,715,264$ & 1,653,681 & $1,597,314$ \\
\hline \multirow[t]{2}{*}{$R^{2}$} & 0.052 & 0.064 & 0.070 & 0.078 & 0.082 & 0.088 & 0.098 & 0.100 & 0.106 & 0.115 & 0.125 \\
\hline & \multicolumn{11}{|c|}{ Panel D: Includes Interaction of Rank with County-Level Crime Rate } \\
\hline$\alpha$ & $-1.506 * * *$ & $-2.269 * * *$ & $-3.264 * * *$ & $-3.774 * * *$ & $-4.321 * * *$ & $-4.497 * * *$ & $-4.402 * * *$ & $-4.363 * * *$ & $-3.992 * * *$ & $-3.580 * * *$ & $-3.186 * * *$ \\
\hline & $(0.0221)$ & $(0.0317)$ & $(0.0419)$ & $(0.0517)$ & $(0.0615)$ & $(0.0668)$ & $(0.0668)$ & $(0.0665)$ & $(0.0629)$ & $(0.0582)$ & $(0.0535)$ \\
\hline \multirow[t]{2}{*}{$\beta$} & $-0.373 * * *$ & $-0.472 * * *$ & $-0.701 * * *$ & $-0.792 * * *$ & $-0.915 * * *$ & $-0.946 * * *$ & $-0.905 * * *$ & $-0.883 * * *$ & $-0.794 * * *$ & $-0.685 * * *$ & $-0.581 * * *$ \\
\hline & $(0.00870)$ & $(0.0120)$ & $(0.0164)$ & $(0.0201)$ & $(0.0240)$ & $(0.0264)$ & $(0.0265)$ & $(0.0264)$ & $(0.0247)$ & $(0.0229)$ & $(0.0209)$ \\
\hline \multirow[t]{2}{*}{$\gamma$} & $0.661^{* * *}$ & $0.945^{* * *}$ & $1.451^{* * *}$ & $1.707 * * *$ & $1.993^{* * *}$ & $2.076^{* * *}$ & $2.014^{* * *}$ & $1.995^{* * *}$ & $1.810^{* * *}$ & $1.592^{* * *}$ & $1.373^{* * *}$ \\
\hline & $(0.0148)$ & $(0.0215)$ & $(0.0285)$ & $(0.0353)$ & $(0.0423)$ & $(0.0462)$ & $(0.0462)$ & $(0.0461)$ & $(0.0435)$ & $(0.0403)$ & $(0.0368)$ \\
\hline$N$ & $5,712,121$ & $5,243,998$ & 4,648,163 & $4,212,602$ & $3,892,093$ & $3,642,926$ & $3,444,118$ & $3,304,200$ & $3,164,169$ & $3,048,826$ & $2,944,256$ \\
\hline$R^{2}$ & 0.050 & 0.063 & 0.069 & 0.076 & 0.081 & 0.087 & 0.095 & 0.098 & 0.105 & 0.115 & 0.126 \\
\hline
\end{tabular}

Note: This table augments the specification in Panel C of Table 3 of the main text by adding the level of the listed variable and its interaction with rank. Panel C includes the log of the ratio of average house prices in the top and bottom third of the price distribution as calculated by Zillow. Panel B includes the crime rate (reported crimes) as reported in the Uniform Crime Reporting Statistics at the county level. 


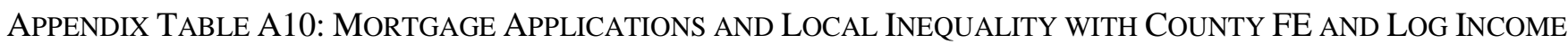

\begin{tabular}{|c|c|c|c|c|c|c|c|c|c|c|c|c|}
\hline & 2001 & 2002 & 2003 & 2004 & 2005 & 2006 & 2007 & 2008 & 2009 & 2010 & 2011 & 2102 \\
\hline \multicolumn{13}{|c|}{ Panel A: Probability of Mortgage Application Being Rejected } \\
\hline$\alpha$ & $\begin{array}{l}-0.022 * * \\
(0.010)\end{array}$ & $\begin{array}{l}0.026^{* * *} \\
(0.008)\end{array}$ & $\begin{array}{l}0.042^{* * *} \\
(0.008)\end{array}$ & $\begin{array}{l}-0.062 * * * \\
(0.008)\end{array}$ & $\begin{array}{c}-0.047 * * * \\
(0.008)\end{array}$ & $\begin{array}{l}-0.041^{* * *} \\
(0.010)\end{array}$ & $\begin{array}{l}-0.006 \\
(0.012)\end{array}$ & $\begin{array}{c}0.001 \\
(0.009)\end{array}$ & $\begin{array}{l}0.121^{* * *} \\
(0.010)\end{array}$ & $\begin{array}{l}0.136 * * * \\
(0.010)\end{array}$ & $\begin{array}{l}0.123^{* * *} \\
(0.011)\end{array}$ & $\begin{array}{l}0.141^{* * *} \\
(0.010)\end{array}$ \\
\hline$\gamma$ & $\begin{array}{l}-0.269 * * * \\
(0.083)\end{array}$ & $\begin{array}{l}-0.220^{* * *} \\
(0.068)\end{array}$ & $\begin{array}{c}-0.177 * * * \\
(0.048)\end{array}$ & $\begin{array}{l}-0.278 * * * \\
(0.036)\end{array}$ & $\begin{array}{c}-0.231 * * * \\
(0.034)\end{array}$ & $\begin{array}{l}-0.259 * * * \\
(0.037)\end{array}$ & $\begin{array}{c}-0.183^{* * *} \\
(0.036)\end{array}$ & $\begin{array}{c}-0.116^{* * *} \\
(0.038)\end{array}$ & $\begin{array}{c}-0.092 * * * \\
(0.030)\end{array}$ & $\begin{array}{c}-0.142^{* * *} \\
(0.036)\end{array}$ & $\begin{array}{l}-0.237 * * * \\
(0.042)\end{array}$ & $\begin{array}{l}-0.231 \text { *** } \\
(0.039)\end{array}$ \\
\hline$N$ & 2244576 & 2264842 & 2520425 & 2635465 & 2970262 & 2663236 & 1921810 & 1319589 & 1240372 & 1275372 & 1196404 & 1381397 \\
\hline$R^{2}$ & 0.124 & 0.095 & 0.069 & 0.062 & 0.057 & 0.056 & 0.059 & 0.047 & 0.043 & 0.055 & 0.072 & 0.082 \\
\hline \multicolumn{13}{|c|}{ Panel B: Probability of Mortgage Being High-Interest (conditional on origination) } \\
\hline$\alpha$ & & & & $\begin{array}{c}-0.077 * * * \\
(0.008)\end{array}$ & $\begin{array}{c}-0.108^{* * *} \\
(0.020)\end{array}$ & $\begin{array}{c}-0.069 * * * \\
(0.019)\end{array}$ & $\begin{array}{c}-0.036^{* * *} \\
(0.009)\end{array}$ & $\begin{array}{l}-0.104 * * * \\
(0.009)\end{array}$ & $\begin{array}{l}-0.040 * * * \\
(0.006)\end{array}$ & $\begin{array}{l}-0.029 * * * \\
(0.005)\end{array}$ & $\begin{array}{l}-0.056^{* * *} \\
(0.006)\end{array}$ & $\begin{array}{l}-0.045^{* * *} \\
(0.006)\end{array}$ \\
\hline$\gamma$ & & & & $\begin{array}{c}-0.159 * * * \\
(0.027)\end{array}$ & $\begin{array}{c}-0.177 * * * \\
(0.039)\end{array}$ & $\begin{array}{c}-0.160 * * * \\
(0.040)\end{array}$ & $\begin{array}{c}-0.135^{* * *} \\
(0.031)\end{array}$ & $\begin{array}{c}-0.109 * * * \\
(0.029)\end{array}$ & $\begin{array}{c}-0.056^{* * *} \\
(0.015)\end{array}$ & $\begin{array}{l}-0.088^{* * * *} \\
(0.016)\end{array}$ & $\begin{array}{l}-0.117 * * * \\
(0.022)\end{array}$ & $\begin{array}{l}-0.106^{* * *} \\
(0.024)\end{array}$ \\
\hline$N$ & & & & 1995005 & 2148955 & 1892164 & 1384324 & 959930 & 944620 & 955348 & 894997 & 1042098 \\
\hline$R^{2}$ & & & & 0.110 & 0.174 & 0.139 & 0.080 & 0.065 & 0.047 & 0.082 & 0.082 & 0.084 \\
\hline \multicolumn{13}{|c|}{ Panel C: Loan-to-Income Ratios of Mortgage Applications (conditional on origination) } \\
\hline$\alpha$ & $\begin{array}{c}-0.587 * * * \\
(0.007)\end{array}$ & $\begin{array}{c}-0.623^{* * *} \\
(0.007)\end{array}$ & $\begin{array}{l}-0.656^{* * *} \\
(0.007)\end{array}$ & $\begin{array}{c}-0.617 * * * \\
(0.007)\end{array}$ & $\begin{array}{c}-0.584 * * * \\
(0.006)\end{array}$ & $\begin{array}{c}-0.598 * * * \\
(0.006)\end{array}$ & $\begin{array}{c}-0.644 * * * \\
(0.006)\end{array}$ & $\begin{array}{c}-0.650 * * * \\
(0.006)\end{array}$ & $\begin{array}{c}-0.680 * * * \\
(0.006)\end{array}$ & $\begin{array}{l}-0.685^{* * *} \\
(0.006)\end{array}$ & $\begin{array}{l}-0.667 * * * \\
(0.007)\end{array}$ & $\begin{array}{c}-0.680 * * * \\
(0.007)\end{array}$ \\
\hline$\gamma$ & $\begin{array}{c}0.044 \\
(0.067)\end{array}$ & $\begin{array}{c}0.030 \\
(0.069)\end{array}$ & $\begin{array}{c}0.078 \\
(0.066)\end{array}$ & $\begin{array}{c}0.094^{*} \\
(0.050)\end{array}$ & $\begin{array}{c}0.019 \\
(0.044)\end{array}$ & $\begin{array}{c}0.014 \\
(0.044)\end{array}$ & $\begin{array}{l}0.095^{* *} \\
(0.041)\end{array}$ & $\begin{array}{c}0.070 \\
(0.049)\end{array}$ & $\begin{array}{c}0.005 \\
(0.052)\end{array}$ & $\begin{array}{c}0.073 \\
(0.054)\end{array}$ & $\begin{array}{c}0.049 \\
(0.058)\end{array}$ & $\begin{array}{c}0.028 \\
(0.060)\end{array}$ \\
\hline$N$ & 1746160 & 1794892 & 1971148 & 1995005 & 2148955 & 1892164 & 1384324 & 959930 & 944620 & 955348 & 894997 & 1042098 \\
\hline$R^{2}$ & 0.327 & 0.349 & 0.371 & 0.352 & 0.336 & 0.349 & 0.371 & 0.380 & 0.403 & 0.408 & 0.390 & 0.394 \\
\hline \multicolumn{13}{|c|}{ Panel A: Log Distance Between Borrower and Lender } \\
\hline$\alpha$ & $\begin{array}{c}0.891 * * * \\
(0.225)\end{array}$ & $\begin{array}{c}1.018 * * * \\
(0.257)\end{array}$ & $\begin{array}{c}0.708^{* * *} \\
(0.213)\end{array}$ & $\begin{array}{c}0.603^{* *} \\
(0.241)\end{array}$ & $\begin{array}{c}1.125^{* * *} \\
(0.251)\end{array}$ & $\begin{array}{c}1.214^{* * *} \\
(0.233)\end{array}$ & $\begin{array}{c}0.949 * * * \\
(0.205)\end{array}$ & $\begin{array}{c}0.970^{* * *} \\
(0.196)\end{array}$ & $\begin{array}{c}0.752^{* * *} \\
(0.152)\end{array}$ & $\begin{array}{c}0.782^{* * *} \\
(0.180)\end{array}$ & $\begin{array}{c}0.869 * * * \\
(0.213)\end{array}$ & $\begin{array}{l}\text { NA } \\
\text { NA }\end{array}$ \\
\hline$\gamma$ & $\begin{array}{c}-0.548 * * * \\
(0.162)\end{array}$ & $\begin{array}{c}-0.616 * * * \\
(0.181)\end{array}$ & $\begin{array}{c}-0.398 * * * \\
(0.153)\end{array}$ & $\begin{array}{c}-0.352 * * \\
(0.172)\end{array}$ & $\begin{array}{c}-0.659 * * * \\
(0.178)\end{array}$ & $\begin{array}{c}-0.686 * * * \\
(0.162)\end{array}$ & $\begin{array}{c}-0.528 * * * \\
(0.147)\end{array}$ & $\begin{array}{c}-0.572 * * * \\
(0.135)\end{array}$ & $\begin{array}{c}-0.411 * * * \\
(0.106)\end{array}$ & $\begin{array}{c}-0.415^{* * *} \\
(0.129)\end{array}$ & $\begin{array}{c}-0.503 * * * \\
(0.152)\end{array}$ & $\begin{array}{l}\text { NA } \\
\text { NA }\end{array}$ \\
\hline$N$ & 512500 & 521088 & 670197 & 682968 & 680922 & 592749 & 613608 & 454283 & 499269 & 518392 & 491535 & NA \\
\hline$R^{2}$ & 0.230 & 0.252 & 0.345 & 0.330 & 0.314 & 0.317 & 0.322 & 0.217 & 0.267 & 0.313 & 0.237 & NA \\
\hline
\end{tabular}

Note: The table replicates the results in Table 8 including the log of the applicant's income. Statistical significance at the $1 \%, 5 \%$, and $10 \%$ levels are indicated by $* * *, * *$, and * respectively. 
APPENDIX TABLE A11: MoRTGAge APPLICATIONS AND LOCAL INEQUALITY WITH STATE FE

\begin{tabular}{|c|c|c|c|c|c|c|c|c|c|c|c|c|}
\hline & 2001 & 2002 & 2003 & 2004 & 2005 & 2006 & 2007 & 2008 & 2009 & 2010 & 2011 & 2102 \\
\hline \multicolumn{13}{|c|}{ Panel A: Probability of Mortgage Application Being Rejected } \\
\hline$\alpha$ & $\begin{array}{l}-0.315^{* * *} \\
(0.012)\end{array}$ & $\begin{array}{l}-0.242^{* * *} \\
(0.010)\end{array}$ & $\begin{array}{l}-0.201 * * * \\
(0.007)\end{array}$ & $\begin{array}{l}-0.203^{* * *} \\
(0.005)\end{array}$ & $\begin{array}{l}-0.205^{* * *} \\
(0.005)\end{array}$ & $\begin{array}{l}-0.163 * * * \\
(0.006)\end{array}$ & $\begin{array}{l}-0.133^{* * *} \\
(0.006)\end{array}$ & $\begin{array}{l}-0.145^{* * *} \\
(0.007)\end{array}$ & $\begin{array}{l}-0.133^{* * *} \\
(0.004)\end{array}$ & $\begin{array}{l}-0.189 * * * \\
(0.006)\end{array}$ & $\begin{array}{l}-0.211 * * * \\
(0.006)\end{array}$ & $\begin{array}{l}-0.221^{* * *} \\
(0.006)\end{array}$ \\
\hline$\beta$ & $\begin{array}{l}0.421 * * * \\
(0.050)\end{array}$ & $\begin{array}{l}0.362 * * * \\
(0.037)\end{array}$ & $\begin{array}{l}0.330 * * * \\
(0.027)\end{array}$ & $\begin{array}{l}0.382 * * * \\
(0.026)\end{array}$ & $\begin{array}{l}0.359 * * * \\
(0.024)\end{array}$ & $\begin{array}{l}0.362 * * * \\
(0.024)\end{array}$ & $\begin{array}{l}0.307 * * * \\
(0.024)\end{array}$ & $\begin{array}{l}0.256 * * * \\
(0.023)\end{array}$ & $\begin{array}{l}0.225 * * * \\
(0.022)\end{array}$ & $\begin{array}{l}0.255^{* * *} \\
(0.028)\end{array}$ & $\begin{array}{l}0.307 * * * \\
(0.030)\end{array}$ & $\begin{array}{l}0.301^{* * *} \\
(0.031)\end{array}$ \\
\hline$\gamma$ & $\begin{array}{l}-0.430^{* * *} \\
(0.089)\end{array}$ & $\begin{array}{l}-0.355^{* * *} \\
(0.073)\end{array}$ & $\begin{array}{l}-0.303^{* * *} \\
(0.054)\end{array}$ & $\begin{array}{l}-0.378^{* * *} \\
(0.038)\end{array}$ & $\begin{array}{l}-0.348^{* * *} \\
(0.035)\end{array}$ & $\begin{array}{l}-0.345^{* * *} \\
(0.038)\end{array}$ & $\begin{array}{l}-0.264^{* * *} \\
(0.036)\end{array}$ & $\begin{array}{l}-0.187 * * * \\
(0.040)\end{array}$ & $\begin{array}{l}-0.204^{* * *} \\
(0.030)\end{array}$ & $\begin{array}{l}-0.285^{* * *} \\
(0.035)\end{array}$ & $\begin{array}{l}-0.397 * * * \\
(0.042)\end{array}$ & $\begin{array}{l}-0.412 * * * \\
(0.040)\end{array}$ \\
\hline $\begin{array}{l}N \\
R^{2}\end{array}$ & $2,244,576$ & $2,264,842$ & $2,520,425$ & $2,635,465$ & $2,970,262$ & $2,663,236$ & $1,921,810$ & $1,319,589$ & $1,240,372$ & $1,275,372$ & $1,196,404$ & 1381397 \\
\hline$R^{2}$ & 0.089 & 0.070 & 0.050 & 0.047 & 0.045 & 0.046 & 0.046 & 0.034 & 0.027 & 0.034 & 0.043 & 0.051 \\
\hline \multicolumn{13}{|c|}{ Panel B: Probability of Mortgage Being High-Interest (conditional on origination) } \\
\hline$\alpha$ & & & & $\begin{array}{l}-0.144^{* * *} \\
(0.005)\end{array}$ & $\begin{array}{l}-0.226 * * * \\
(0.008)\end{array}$ & $\begin{array}{l}-0.186^{* * *} \\
(0.009)\end{array}$ & $\begin{array}{l}-0.133^{* * *} \\
(0.006)\end{array}$ & $\begin{array}{l}-0.167 * * * \\
(0.005)\end{array}$ & $\begin{array}{l}-0.090 * * * \\
(0.003)\end{array}$ & $\begin{array}{l}-0.083^{* * *} \\
(0.003)\end{array}$ & $\begin{array}{l}-0.105^{* * *} \\
(0.004)\end{array}$ & $\begin{array}{l}-0.105^{* * *} \\
(0.004)\end{array}$ \\
\hline$\beta$ & & & & $\begin{array}{l}0.244^{* * *} \\
(0.025)\end{array}$ & $\begin{array}{l}0.295 * * * \\
(0.036)\end{array}$ & $\begin{array}{l}0.282 * * * \\
(0.036)\end{array}$ & $\begin{array}{l}0.204 * * * \\
(0.024)\end{array}$ & $\begin{array}{l}0.157 * * * \\
(0.024)\end{array}$ & $\begin{array}{l}0.083 * * * \\
(0.014)\end{array}$ & $\begin{array}{l}0.110 * * * \\
(0.013)\end{array}$ & $\begin{array}{l}0.123 * * * \\
(0.017)\end{array}$ & $\begin{array}{l}0.129 * * * \\
(0.018)\end{array}$ \\
\hline$\gamma$ & & & & $\begin{array}{l}-0.213^{* * *} \\
(0.028)\end{array}$ & $\begin{array}{l}-0.289 * * * \\
(0.039)\end{array}$ & $\begin{array}{l}-0.268^{* * *} \\
(0.040)\end{array}$ & $\begin{array}{l}-0.202 * * * \\
(0.031)\end{array}$ & $\begin{array}{l}-0.139 * * * \\
(0.028)\end{array}$ & $\begin{array}{l}-0.073 * * * \\
(0.015)\end{array}$ & $\begin{array}{l}-0.105 * * * \\
(0.016)\end{array}$ & $\begin{array}{l}-0.129 * * * \\
(0.022)\end{array}$ & $\begin{array}{l}-0.125 * * * \\
(0.024)\end{array}$ \\
\hline$N$ & & & & 1995005 & 2148955 & 1892164 & 1384324 & 959930 & 944620 & 955348 & 894997 & 1042098 \\
\hline$R^{2}$ & & & & 0.099 & $\begin{array}{c}0.159 \\
\end{array}$ & 0.123 & 0.063 & 0.047 & 0.027 & 0.042 & 0.044 & 0.047 \\
\hline \multicolumn{13}{|c|}{ Panel C: Loan-to-Income Ratios of Mortgage Applications (conditional on origination) } \\
\hline$\alpha$ & $\begin{array}{l}-0.579 * * * \\
(0.007)\end{array}$ & $\begin{array}{l}-0.613^{* * *} \\
(0.007)\end{array}$ & $\begin{array}{l}-0.643^{* * *} \\
(0.007)\end{array}$ & $\begin{array}{l}-0.607 * * * \\
(0.007)\end{array}$ & $\begin{array}{l}-0.577^{* * *} \\
(0.006)\end{array}$ & $\begin{array}{l}-0.591^{* * *} \\
(0.006)\end{array}$ & $\begin{array}{l}-0.639 * * * \\
(0.006)\end{array}$ & $\begin{array}{l}-0.643 * * * \\
(0.006)\end{array}$ & $\begin{array}{l}-0.673^{* * *} \\
(0.006)\end{array}$ & $\begin{array}{l}-0.679 * * * \\
(0.006)\end{array}$ & $\begin{array}{l}-0.662 * * * \\
(0.007)\end{array}$ & $\begin{array}{c}-0.670^{* * *} \\
(0.006)\end{array}$ \\
\hline$\beta$ & $\begin{array}{l}-0.224 * * * \\
(0.049)\end{array}$ & $\begin{array}{l}-0.222 * * * \\
(0.051)\end{array}$ & $\begin{array}{l}-0.252^{* * *} \\
(0.052)\end{array}$ & $\begin{array}{l}-0.273^{* * *} \\
(0.050)\end{array}$ & $\begin{array}{l}-0.228^{* * *} \\
(0.043)\end{array}$ & $\begin{array}{l}-0.233^{* * *} \\
(0.039)\end{array}$ & $\begin{array}{l}-0.259 * * * \\
(0.041)\end{array}$ & $\begin{array}{l}-0.187 * * * \\
(0.051)\end{array}$ & $\begin{array}{l}-0.105^{* *} \\
(0.049)\end{array}$ & $\begin{array}{l}-0.133^{* * *} \\
(0.046)\end{array}$ & $\begin{array}{l}-0.105 * * \\
(0.048)\end{array}$ & $\begin{array}{c}-0.097 * * \\
(0.046)\end{array}$ \\
\hline$\gamma$ & $\begin{array}{c}0.076 \\
(0.068)\end{array}$ & $\begin{array}{c}0.059 \\
(0.069)\end{array}$ & $\begin{array}{c}0.110 \\
(0.068)\end{array}$ & $\begin{array}{l}0.139 * * * \\
(0.052)\end{array}$ & $\begin{array}{c}0.060 \\
(0.048)\end{array}$ & $\begin{array}{c}0.050 \\
(0.047)\end{array}$ & $\begin{array}{l}0.118^{* * *} \\
(0.045)\end{array}$ & $\begin{array}{c}0.082 \\
(0.051)\end{array}$ & $\begin{array}{c}0.021 \\
(0.054)\end{array}$ & $\begin{array}{c}0.080 \\
(0.056)\end{array}$ & $\begin{array}{c}0.049 \\
(0.060)\end{array}$ & $\begin{array}{r}0.049 \\
(0.062)\end{array}$ \\
\hline$N$ & 1746160 & 1794892 & 1971148 & 1995005 & 2148955 & 1892164 & 1384324 & 959930 & 944620 & 955348 & 894997 & 1042098 \\
\hline$R^{2}$ & 0.291 & 0.314 & 0.333 & 0.318 & 0.307 & 0.322 & 0.342 & 0.345 & 0.365 & 0.375 & 0.359 & 0.362 \\
\hline \multicolumn{13}{|c|}{ Panel A: Log Distance Between Borrower and Lender } \\
\hline$\alpha$ & $\begin{array}{c}0.915 * * * \\
(0.265)\end{array}$ & $\begin{array}{c}0.962 * * * \\
(0.303)\end{array}$ & $\begin{array}{c}0.653 * * * \\
(0.173)\end{array}$ & $\begin{array}{c}0.595 * * \\
(0.236)\end{array}$ & $\begin{array}{c}1.254^{* * *} \\
(0.210)\end{array}$ & $\begin{array}{c}1.348^{* * *} \\
(0.229)\end{array}$ & $\begin{array}{c}1.015^{* * *} \\
(0.168)\end{array}$ & $\begin{array}{c}1.019 * * * \\
(0.168)\end{array}$ & $\begin{array}{c}0.611^{* * * *} \\
(0.157)\end{array}$ & $\begin{array}{c}0.628^{* * *} \\
(0.174)\end{array}$ & $\begin{array}{c}5.268 * * * \\
(1.836)\end{array}$ & $\begin{array}{l}\text { NA } \\
\text { NA }\end{array}$ \\
\hline$\beta$ & $\begin{array}{c}-1.371^{* * *} \\
(0.220)\end{array}$ & $\begin{array}{c}-1.277 * * * \\
(0.253)\end{array}$ & $\begin{array}{c}-1.291 * * * \\
(0.264)\end{array}$ & $\begin{array}{c}-1.129 * * * \\
(0.266)\end{array}$ & $\begin{array}{c}-0.856 * * * \\
(0.227)\end{array}$ & $\begin{array}{c}-0.636^{* *} \\
(0.270)\end{array}$ & $\begin{array}{c}-0.549 * * \\
(0.219)\end{array}$ & $\begin{array}{c}-0.558^{* *} \\
(0.231)\end{array}$ & $\begin{array}{c}-0.896 * * * \\
(0.214)\end{array}$ & $\begin{array}{c}-0.884^{* * * *} \\
(0.191)\end{array}$ & $\begin{array}{c}-4.608 * * * \\
(1.381)\end{array}$ & $\begin{array}{l}\text { NA } \\
\text { NA }\end{array}$ \\
\hline$\gamma$ & $\begin{array}{c}-0.513^{* *} \\
(0.196)\end{array}$ & $\begin{array}{c}-0.551 * * \\
(0.221)\end{array}$ & $\begin{array}{c}-0.358^{* * *} \\
(0.125)\end{array}$ & $\begin{array}{l}-0.327 * \\
(0.166)\end{array}$ & $\begin{array}{c}-0.794 * * * \\
(0.153)\end{array}$ & $\begin{array}{c}-0.856 * * * \\
(0.166)\end{array}$ & $\begin{array}{c}-0.618^{* * *} \\
(0.121)\end{array}$ & $\begin{array}{c}-0.623 * * * \\
(0.119)\end{array}$ & $\begin{array}{c}-0.355^{* * *} \\
(0.113)\end{array}$ & $\begin{array}{c}-0.367 * * * \\
(0.126)\end{array}$ & $\begin{array}{c}-3.381 * * \\
(1.292)\end{array}$ & $\begin{array}{l}\text { NA } \\
\text { NA }\end{array}$ \\
\hline$N$ & 512500 & 521088 & 670197 & 682968 & 680922 & 592749 & 613608 & 454283 & 499269 & 518392 & 491535 & NA \\
\hline$R^{2}$ & 0.073 & 0.091 & 0.205 & 0.196 & 0.182 & 0.180 & 0.190 & 0.059 & 0.124 & 0.168 & 0.080 & NA \\
\hline
\end{tabular}

Note: The table replicates the results in Table 8 using state fixed effects rather than county fixed effects. Statistical significance at the $1 \%, 5 \%$, and $10 \%$ levels are indicated by $* * *$, **, and * respectively. 
Appendix TABle A12: Mortgage ApPlications and LoCAL INEQUALITY With StATE FE AND INCOME

\begin{tabular}{|c|c|c|c|c|c|c|c|c|c|c|c|c|}
\hline & 2001 & 2002 & 2003 & 2004 & 2005 & 2006 & 2007 & 2008 & 2009 & 2010 & 2011 & 2102 \\
\hline \multicolumn{13}{|c|}{ Panel A: Probability of Mortgage Application Being Rejected } \\
\hline$\alpha$ & $\begin{array}{l}-0.005 \\
(0.017)\end{array}$ & $\begin{array}{c}0.003 \\
(0.014)\end{array}$ & $\begin{array}{l}0.027^{* *} \\
(0.010)\end{array}$ & $\begin{array}{l}-0.035^{* * *} \\
(0.009)\end{array}$ & $\begin{array}{l}-0.050^{* * *} \\
(0.009)\end{array}$ & $\begin{array}{l}-0.040^{* * *} \\
(0.010)\end{array}$ & $\begin{array}{l}-0.014 \\
(0.011)\end{array}$ & $\begin{array}{l}-0.040 * * \\
(0.017)\end{array}$ & $\begin{array}{l}0.047 * * * \\
(0.013)\end{array}$ & $\begin{array}{l}0.049 * * * \\
(0.014)\end{array}$ & $\begin{array}{l}0.073^{* * *} \\
(0.014)\end{array}$ & $\begin{array}{l}0.111^{* * *} \\
(0.016)\end{array}$ \\
\hline$\beta$ & $\begin{array}{l}0.254 * * * \\
(0.041)\end{array}$ & $\begin{array}{l}0.242 * * * \\
(0.031)\end{array}$ & $\begin{array}{l}0.232 * * * \\
(0.021)\end{array}$ & $\begin{array}{l}0.303^{* * *} \\
(0.021)\end{array}$ & $\begin{array}{l}0.288^{* * *} \\
(0.020)\end{array}$ & $\begin{array}{l}0.307 * * * \\
(0.021)\end{array}$ & $\begin{array}{l}0.258^{* * *} \\
(0.022)\end{array}$ & $\begin{array}{l}0.218^{* * *} \\
(0.023)\end{array}$ & $\begin{array}{l}0.174^{* * *} \\
(0.020)\end{array}$ & $\begin{array}{l}0.196 * * * \\
(0.025)\end{array}$ & $\begin{array}{l}0.237 * * * \\
(0.027)\end{array}$ & $\begin{array}{l}0.209 * * * \\
(0.028)\end{array}$ \\
\hline$\gamma$ & $\begin{array}{l}-0.265^{* * *} \\
(0.089)\end{array}$ & $\begin{array}{l}-0.228 * * * \\
(0.072)\end{array}$ & $\begin{array}{l}-0.188 * * * \\
(0.053)\end{array}$ & $\begin{array}{l}-0.274^{* * *} \\
(0.038)\end{array}$ & $\begin{array}{l}-0.247^{* * *} \\
(0.035)\end{array}$ & $\begin{array}{l}-0.269 * * * \\
(0.038)\end{array}$ & $\begin{array}{l}-0.196 * * * \\
(0.037)\end{array}$ & $\begin{array}{l}-0.135^{* * *} \\
(0.041)\end{array}$ & $\begin{array}{l}-0.121^{* * *} \\
(0.031)\end{array}$ & $\begin{array}{l}-0.183^{* * *} \\
(0.036)\end{array}$ & $\begin{array}{l}-0.274^{* * *} \\
(0.043)\end{array}$ & $\begin{array}{l}-0.259 * * * \\
(0.041)\end{array}$ \\
\hline$N$ & 2244576 & 2264842 & 2520425 & 2635465 & 2970262 & 2663236 & 1921810 & 1319589 & 1240372 & 1275372 & 1196404 & 1381397 \\
\hline$R^{2}$ & 0.098 & 0.076 & 0.054 & 0.050 & 0.047 & 0.047 & 0.048 & 0.035 & 0.030 & 0.040 & 0.051 & 0.060 \\
\hline \multicolumn{13}{|c|}{ Panel B: Probability of Mortgage Being High-Interest (conditional on origination) } \\
\hline$\alpha$ & & & & $\begin{array}{l}-0.035 * * * \\
(0.009)\end{array}$ & $\begin{array}{l}-0.049 * * * \\
(0.016)\end{array}$ & $\begin{array}{l}-0.018 \\
(0.017)\end{array}$ & $\begin{array}{c}0.007 \\
(0.010)\end{array}$ & $\begin{array}{l}-0.042^{* * *} \\
(0.009)\end{array}$ & $\begin{array}{c}0.001 \\
(0.006)\end{array}$ & $\begin{array}{l}-0.002 \\
(0.006)\end{array}$ & $\begin{array}{c}0.003 \\
(0.007)\end{array}$ & $\begin{array}{l}-0.001 \\
(0.007)\end{array}$ \\
\hline$\beta$ & & & & $\begin{array}{l}0.191 * * * \\
(0.023)\end{array}$ & $\begin{array}{l}0.208^{* * *} \\
(0.032)\end{array}$ & $\begin{array}{l}0.202^{* * *} \\
(0.032)\end{array}$ & $\begin{array}{l}0.142 * * * \\
(0.022)\end{array}$ & $\begin{array}{l}0.110^{* * *} \\
(0.022)\end{array}$ & $\begin{array}{l}0.056^{* * *} \\
(0.012)\end{array}$ & $\begin{array}{l}0.090^{* * *} \\
(0.012)\end{array}$ & $\begin{array}{l}0.096 * * * \\
(0.015)\end{array}$ & $\begin{array}{l}0.100^{* * *} \\
(0.016)\end{array}$ \\
\hline$\gamma$ & & & & $\begin{array}{l}-0.146 * * * \\
(0.028)\end{array}$ & $\begin{array}{l}-0.174 * * * \\
(0.040)\end{array}$ & $\begin{array}{l}-0.166 * * * \\
(0.042)\end{array}$ & $\begin{array}{l}-0.124 * * * \\
(0.032)\end{array}$ & $\begin{array}{l}-0.080^{* * *} \\
(0.029)\end{array}$ & $\begin{array}{l}-0.034 * * \\
(0.015)\end{array}$ & $\begin{array}{l}-0.071 * * * \\
(0.016)\end{array}$ & $\begin{array}{l}-0.085^{* * *} \\
(0.022)\end{array}$ & $\begin{array}{l}-0.079 * * * \\
(0.024)\end{array}$ \\
\hline$N$ & & & & 1995005 & 2148955 & 1892164 & 1384324 & 959930 & 944620 & 955348 & 894997 & 1042098 \\
\hline$R^{2}$ & & & & 0.100 & 0.162 & 0.125 & 0.066 & 0.050 & 0.029 & 0.045 & 0.047 & 0.050 \\
\hline \multicolumn{13}{|c|}{ Panel C: Loan-to-Income Ratios of Mortgage Applications (conditional on origination) } \\
\hline$\alpha$ & $\begin{array}{l}-0.579 * * * \\
(0.007)\end{array}$ & $\begin{array}{l}-0.613^{* * *} \\
(0.007)\end{array}$ & $\begin{array}{l}-0.643^{* * *} \\
(0.007)\end{array}$ & $\begin{array}{l}-0.607^{* * *} \\
(0.007)\end{array}$ & $\begin{array}{l}-0.577^{* * *} \\
(0.006)\end{array}$ & $\begin{array}{l}-0.591^{* * *} \\
(0.006)\end{array}$ & $\begin{array}{l}-0.639^{* * *} \\
(0.006)\end{array}$ & $\begin{array}{l}-0.643^{* * *} \\
(0.006)\end{array}$ & $\begin{array}{l}-0.673 * * * \\
(0.006)\end{array}$ & $\begin{array}{l}-0.679 * * * \\
(0.006)\end{array}$ & $\begin{array}{l}-0.662 * * * \\
(0.007)\end{array}$ & $\begin{array}{c}-0.670^{* * *} \\
(0.006)\end{array}$ \\
\hline$\beta$ & $\begin{array}{l}-0.224^{* * *} \\
(0.049)\end{array}$ & $\begin{array}{l}-0.222 * * * \\
(0.051)\end{array}$ & $\begin{array}{l}-0.252 * * * \\
(0.052)\end{array}$ & $\begin{array}{l}-0.273^{* * *} \\
(0.050)\end{array}$ & $\begin{array}{l}-0.228^{* * *} \\
(0.043)\end{array}$ & $\begin{array}{l}-0.233 * * * \\
(0.039)\end{array}$ & $\begin{array}{l}-0.259 * * * \\
(0.041)\end{array}$ & $\begin{array}{l}-0.187 * * * \\
(0.051)\end{array}$ & $\begin{array}{l}-0.105^{* *} \\
(0.049)\end{array}$ & $\begin{array}{l}-0.133^{* * *} \\
(0.046)\end{array}$ & $\begin{array}{l}-0.105^{* *} \\
(0.048)\end{array}$ & $\begin{array}{c}-0.097 * * \\
(0.046)\end{array}$ \\
\hline$\gamma$ & $\begin{array}{c}0.076 \\
(0.068)\end{array}$ & $\begin{array}{c}0.059 \\
(0.069)\end{array}$ & $\begin{array}{c}0.110 \\
(0.068)\end{array}$ & $\begin{array}{l}0.139 * * * \\
(0.052)\end{array}$ & $\begin{array}{c}0.060 \\
(0.048)\end{array}$ & $\begin{array}{c}0.050 \\
(0.047)\end{array}$ & $\begin{array}{l}0.118^{* * *} \\
(0.045)\end{array}$ & $\begin{array}{c}0.082 \\
(0.051)\end{array}$ & $\begin{array}{c}0.021 \\
(0.054)\end{array}$ & $\begin{array}{c}0.080 \\
(0.056)\end{array}$ & $\begin{array}{c}0.049 \\
(0.060)\end{array}$ & $\begin{array}{c}0.049 \\
(0.062)\end{array}$ \\
\hline$N$ & 1746160 & 1794892 & 1971148 & 1995005 & 2148955 & 1892164 & 1384324 & 959930 & 944620 & 955348 & 894997 & 1042098 \\
\hline$R^{2}$ & 0.291 & 0.314 & 0.333 & 0.318 & 0.307 & 0.322 & 0.342 & 0.345 & 0.365 & 0.375 & 0.359 & 0.362 \\
\hline \multicolumn{13}{|c|}{ Panel A: Log Distance Between Borrower and Lender } \\
\hline$\alpha$ & $\begin{array}{c}0.990 * * * \\
(0.271)\end{array}$ & $\begin{array}{c}1.101 * * * \\
(0.330)\end{array}$ & $\begin{array}{c}0.755 * * * \\
(0.214)\end{array}$ & $\begin{array}{c}0.679 * * \\
(0.271)\end{array}$ & $\begin{array}{c}1.328 * * * \\
(0.214)\end{array}$ & $\begin{array}{c}1.440 * * * \\
(0.262)\end{array}$ & $\begin{array}{c}1.117^{* * *} \\
(0.196)\end{array}$ & $\begin{array}{c}1.138 * * * \\
(0.160)\end{array}$ & $\begin{array}{c}0.728 * * * \\
(0.162)\end{array}$ & $\begin{array}{c}0.755 * * * \\
(0.175)\end{array}$ & $\begin{array}{c}0.860 * * * \\
(0.159)\end{array}$ & $\begin{array}{l}\text { NA } \\
\text { NA }\end{array}$ \\
\hline$\beta$ & $\begin{array}{c}-1.449 * * * \\
(0.223)\end{array}$ & $\begin{array}{c}-1.396 * * * \\
(0.240)\end{array}$ & $\begin{array}{c}-1.389 * * * \\
(0.249)\end{array}$ & $\begin{array}{c}-1.227 * * * \\
(0.244)\end{array}$ & $\begin{array}{c}-0.966 * * * \\
(0.233)\end{array}$ & $\begin{array}{c}-0.771 * * * \\
(0.279)\end{array}$ & $\begin{array}{c}-0.668^{* * *} \\
(0.230)\end{array}$ & $\begin{array}{c}-0.672 * * * \\
(0.235)\end{array}$ & $\begin{array}{c}-1.017 * * * \\
(0.206)\end{array}$ & $\begin{array}{c}-0.982 * * * \\
(0.184)\end{array}$ & $\begin{array}{c}-0.845^{* * *} \\
(0.158)\end{array}$ & $\begin{array}{l}\text { NA } \\
\text { NA }\end{array}$ \\
\hline$\gamma$ & $\begin{array}{l}-0.411^{*} \\
(0.205)\end{array}$ & $\begin{array}{c}-0.394 * * \\
(0.193)\end{array}$ & $\begin{array}{l}-0.220^{*} \\
(0.121)\end{array}$ & $\begin{array}{l}-0.197 \\
(0.138)\end{array}$ & $\begin{array}{c}-0.647 * * * \\
(0.134)\end{array}$ & $\begin{array}{c}-0.683 * * * \\
(0.142)\end{array}$ & $\begin{array}{c}-0.471 * * * \\
(0.122)\end{array}$ & $\begin{array}{c}-0.479 * * * \\
(0.132)\end{array}$ & $\begin{array}{l}-0.216^{*} \\
(0.123)\end{array}$ & $\begin{array}{l}-0.252^{*} \\
(0.127)\end{array}$ & $\begin{array}{c}-0.480 * * * \\
(0.116)\end{array}$ & $\begin{array}{l}\text { NA } \\
\text { NA }\end{array}$ \\
\hline$N$ & 512500 & 521088 & 670197 & 682968 & 680922 & 592749 & 613608 & 454283 & 499269 & 518392 & 491535 & NA \\
\hline$R^{2}$ & 0.230 & 0.252 & 0.345 & 0.330 & 0.314 & 0.317 & 0.322 & 0.217 & 0.267 & 0.313 & 0.237 & NA \\
\hline
\end{tabular}

Note: The table replicates the results in Table 8 using state fixed effects rather than county fixed effects and including the log of applicant income. Statistical significance at the $1 \%, 5 \%$, and $10 \%$ levels are indicated by $* * *, * *$, and * respectively 


\section{Appendix Figure 1 DeBt ACCumulation by LOW, Medium AND High-RANK HouseholdS AND LOCAL INEQUALITY, NONPARAMETRIC SPECIFICATION}

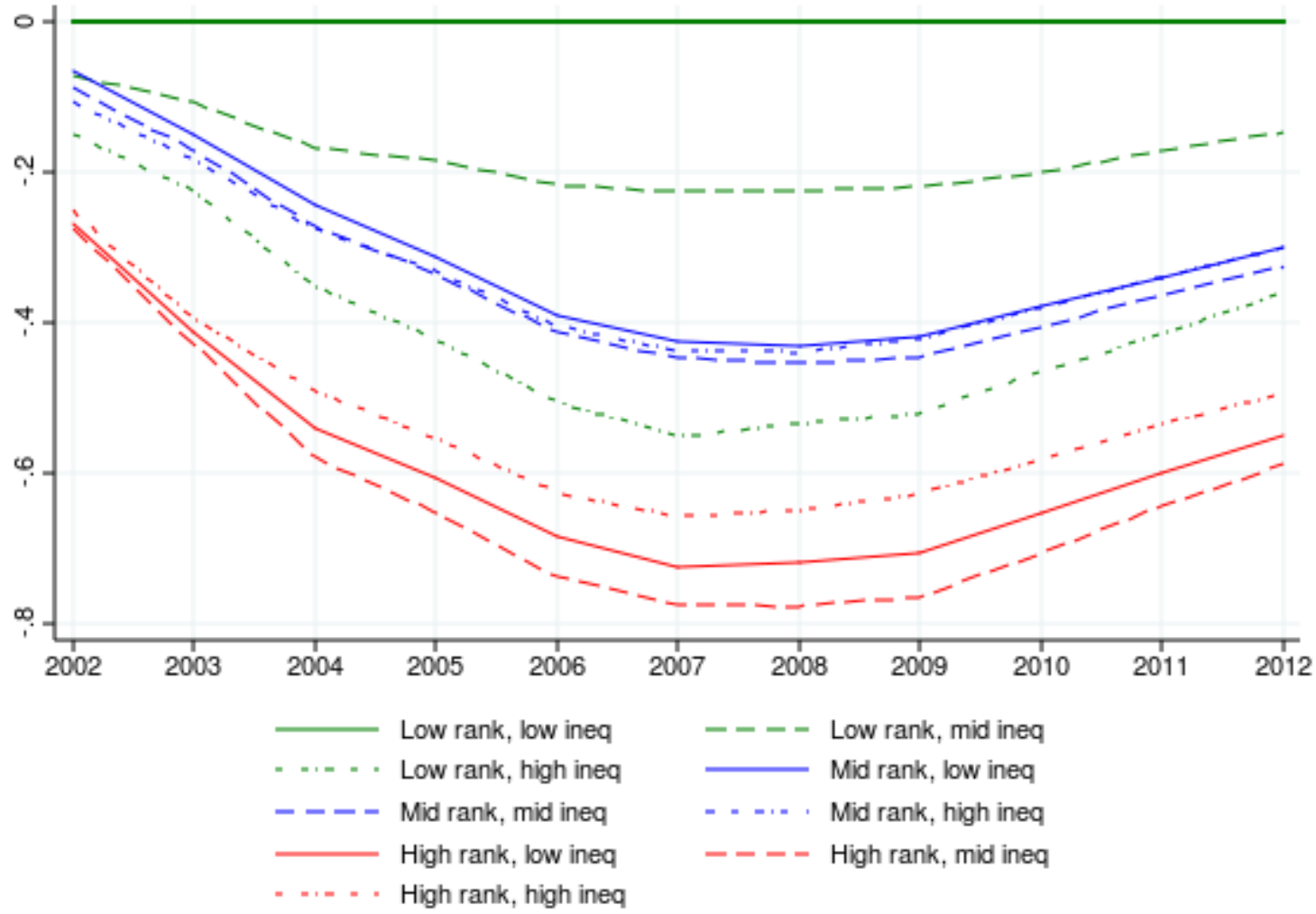

Note: The figure shows the full set of estimated coefficients on the income rank dummies from the nonparametric regressions of the relative household debt accumulation between 2001 and year $t$. Each regression contains dummies for income ranks and inequality levels (with low-rank households in low-inequality regions being the benchmark), and a full set of controls described in equation (3) and the county-specific fixed effects. See section 3.4 for details. 


\section{APPENDIX B: ADDITIONAL INFORMATION ON CCP DATA}

The Equifax FRBNY Consumer Credit Panel is a longitudinal database with detailed information on consumer debt and credit. The core of the database constitutes a 5\% random sample of all U.S. individuals with credit (i.e., the primary sample). The database also contains information on all individuals with credit files residing in the same household as the individuals in the primary sample. The household members are added to the sample based on the mailing address in the existing credit files. Thus, the resulting sample is a sample of U.S. households in which at least one member has a credit file.

The individual records in the CCP contain information on the mortgage debt, credit card debt and credit card limits, home equity lines of credit, student loans, auto loans, bankruptcy and delinquencies. The data include residential location on the census block level and the birth year of individuals. The data in the CCP are updated quarterly. We use $100 \%$ of the CCP sample.

The unit of the analysis in the paper is a household. The CCP is primarily an individual-level dataset; however, it contains two identifiers that allow us to construct the household records in each period and then link the household records from period to period. In each quarter, a unique (household) identifier is given for all individuals who reside in the same household as an individual in the primary sample. We use this identifier to aggregate the individual level information to construct the household level credit variables. We restrict the analysis to households with at most 10 members.

The household identifier identifies household members only in one period. We then use the second identifier in the CCP data, an individual identifier that remains constant from period to period, to link household records from one quarter to another. To construct the longitudinal household record, we proceed as follows. Let $i$ denote the identification number of a household in 2001. To identify the continuation of household $i$ in year $t$, $t>2001$, we first determine what members of household $i$ are present in year $t$ using individual identifiers. We then determine the identification number of the household to which each member of household $i$ belongs to in year $t$. If there is more than one such household, we flag the modal household, if one exists. Let $j$ denote this modal household. We then repeat the procedure in reverse: consider all members of household $j$ who are present in year $t$ and determine what members of household $j$ are present in year 2001 using individual identifiers, determine the identification number of the household to which each member of household $j$ belongs to in year 2001. If there is more than one such household, we flag the modal household, if one exists. Let $i^{\prime}$ denote this modal household. If $i^{\prime}$ equals $i^{\prime}$, we identify $j$ as a continuation record for household $i$. While the primary sample of individuals in the CCP is a random sample of all U.S. households with credit reports; the resulting sample of the households is not random. Following, Lee and van der Klaauw (2010) we define the sampling weights as the inverse of the probability to be included in the sample, $w_{h}=\frac{1}{1-.05^{N}}$, where $N$ is the number of individuals in the household who are in the primary sample.

For each individual, the data contain a record of her debt by detailed category as well as a record of the balances on the joint or cosigned accounts. In aggregating the debt on the household level, we use a correction to avoid double counting of the balances on joint accounts. This choice follows Brown, Haughwout, Lee and van der Klaauw (2011). In particular, while aggregating, we discount the total debt of the household members by $50 \%$ of the total debt on joint accounts of the household members. The exact formula that we use is

$$
d_{h, j}=\max \left\{\sum_{i}\left(d_{h, j}^{i}-.5 d_{h, j}^{i, c}\right), .5 d_{h, j}^{i, c}\right\} .
$$

Where $d_{h, j}^{i}$ is the total debt in category $j$ of member $i$ in household $h$ and $d_{h, j}^{i, c}$ is the debt in joint accounts. The second input to the maximum function addresses the situation that arises with so-called "thin" credit records, or records with at most two credit report-worthy debts. The individuals with thin records are not included in the 
primary sample, but they are included in the additional sample. These individuals might have records on joint accounts that are missed on individual accounts. We thank Donghoon Lee for this suggestion.

\section{Variable Descriptions}

Here we provide a short description of the variables used in the CCP analysis. For a detailed description of the CCP dataset please see Lee and van der Klaauw (2010).

Age: We follow Brown, Haughwout, Lee, and van der Klaauw (2011) and define age as the median age of adult members of the house.

Auto debts: These are any loans taken out explicitly for the purchase of a car including loans from banks and those from automobile financing institutions.

Bankruptcy: An indicator in the CCP taken from public records that detail whether or not an individual has filed for bankruptcy.

Credit Card Balance: The sum of reported balances across bank cards as well as retail cards. These cards reflect revolving accounts at banks, credit unions, credit card companies, and others. Importantly, the CCP does not distinguish between balances rolled over billing periods (and so potentially subject to interest charges) and cards where the balance is paid every month.

Credit Card Limits: We take the maximum of reported limits and balances across all bank and retail cards to ensure that reported utilization is not greater than one.

Credit Card Utilization Rate: This is the ratio of the credit card balance and credit card limit.

Delinquency: Indicator for whether or not a household is at least 60 days delinquent on any of its accounts in the current quarter.

HELOC Debt: The sum of home equity lines of credit, or home equity revolving accounts. We use the classification of HELOCs vs. installment loans provided by the CCP data.

Mortgage Debt: The sum of all mortgage installment loans.

Riskscore: A variable constructed by Equifax and similar to FICO. A higher number is interpreted as a lower default risk. We construct the household riskscore by taking the average of individual riskscores within the household.

Size: Household size sums the number of distinct social security numbers that can be linked by household identifiers in a specific time period. We restrict the household size to at most 10.

Student Loans: These include loans financing education from private and public institutions.

Total debt: Constructed as the sum of mortgage debt balance, credit card balances, auto debts, balance on home equity lines of credit, and student loans. 


\section{APPENDIX C: DECOMPOSING U.S. INEQUALITY SINCE 1970}

The decomposition is constructed using the following IPUMS samples: 1970, 1980, 1\% metro samples and the 1990 and $20001 \%$ unweighted sample. Within each of these samples we use the metro area geographies defined by IPUMS in the following way:

"Metropolitan areas are counties or combinations of counties centering on a substantial urban area.

METAREA identifies the metropolitan area where the household was enumerated, if that metropolitan area was large enough to meet confidentiality requirements.”

We restrict the sample to the set of metro areas that can be identified in each year to get 117 metro areas containing roughly $60 \%$ of the entire sample within each year. We also restrict the sample to households where the respondent's age is between 25 and 65 and the respondent is the head of the household or the spouse of the head of the household. These restrictions are not important for the results.

To calculate income we use family total income. While not exactly the same as household income it is available for all years whereas household income is not available in 1970. We estimate the following model of $\log$ family income on each year of the sample:

$$
\log \left(y_{i a}\right)=\alpha_{a}+\epsilon_{i}
$$

Estimating this function gives estimates of the variance of the fixed effects and the variance of the residuals for each year. We then calculate the share of variance explained by variance of the fixed effects as:

$$
\text { Share }=\frac{\hat{\sigma}_{a}^{2}}{\hat{\sigma}_{a}^{2}+\hat{\sigma}_{i}^{2}}
$$

\section{APPENDIX FiguRE C1: DECOMPOSING AgGREgATE U.S. INEQUALITY}
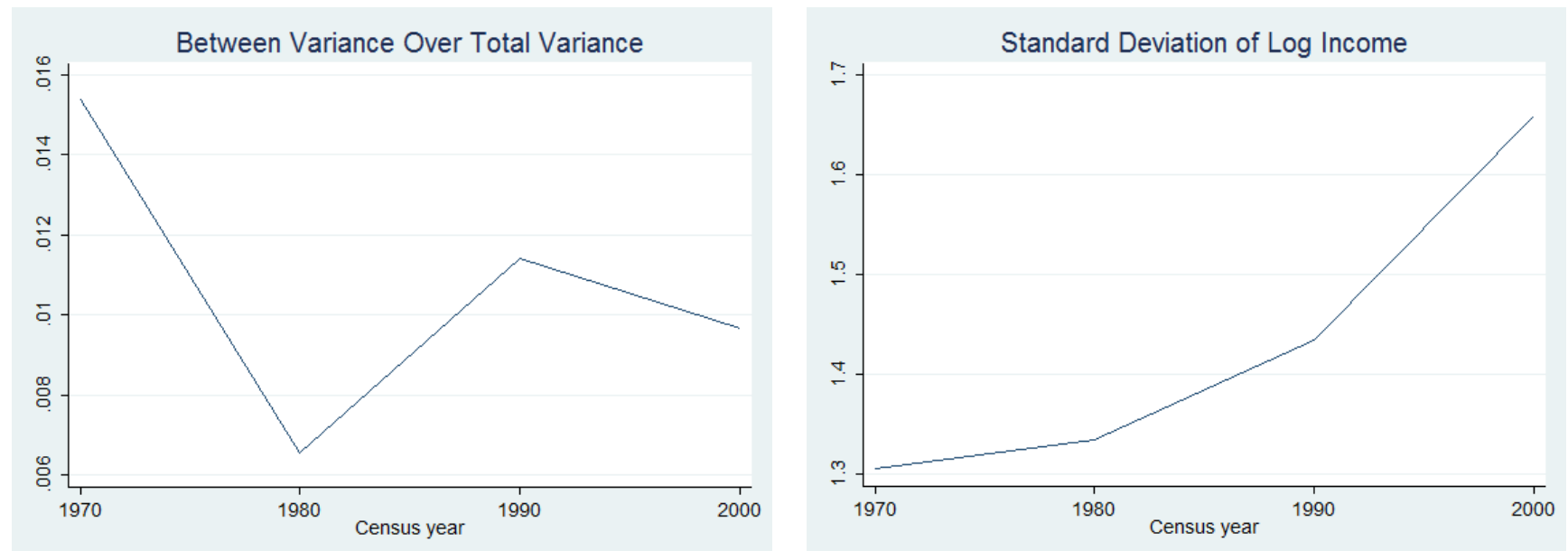

Note: The left-hand figure plots the ratio of "between" variance of mean incomes to the total variance of incomes. The right-hand figure plots the standard deviation of log income across all households. 


\section{APPENDIX D: TIME VARIATION IN LOCAL INEQUALITY RATES}

To get a sense of how inequality within counties has varied across time we computed Gini coefficients at the county level using 1970 and 2000 Census aggregates available from ICPSR. To compute the Gini coefficient we follow the same procedure outlined in the Appendix and reproduced below. Because the number of bins used to compute the coefficient is not the same in both years (1970 has fewer bins) the levels of the Gini coefficients are not directly comparable. Using the Census data we match 3,122 counties.

Let $f\left(y_{i}\right)$ be a discrete probability function where $i=1, \ldots, n$ and $y_{i}<y_{i+1}$. Then the Gini coefficient $G$ is defined as

$$
G=1-\frac{\sum_{i=1}^{n} f\left(y_{i}\right)\left(S_{i-1}+S_{i}\right)}{S_{n}}
$$

where $S_{i}=\sum_{j=1}^{i} f\left(y_{j}\right) y_{j}$ and $S_{0}=0$.

We approximate the discrete probability function with the share of a location's population within each bin reported by the Census. For all bins but the last we assume all the mass is distributed at the midpoint of the bin. For the very last bin we add the last increment to the lower boundary. For example, if the last bin is incomes of $\$ 200,000$ and up and the bin before was $\$ 150,000$ to $\$ 199,999$ we assign the last bin to have the value $\$ 250,000$. This assumption limits the impact the very top bin will have on the coefficient, but should provide a reasonable approximation of inequality at low levels of aggregation.

The figure reported below shows a high degree of correlation between inequality in 1970 and inequality in 2000. The R-squared is 0.26 and the Spearman correlation is 0.52 , suggesting inequality is quite persistent.

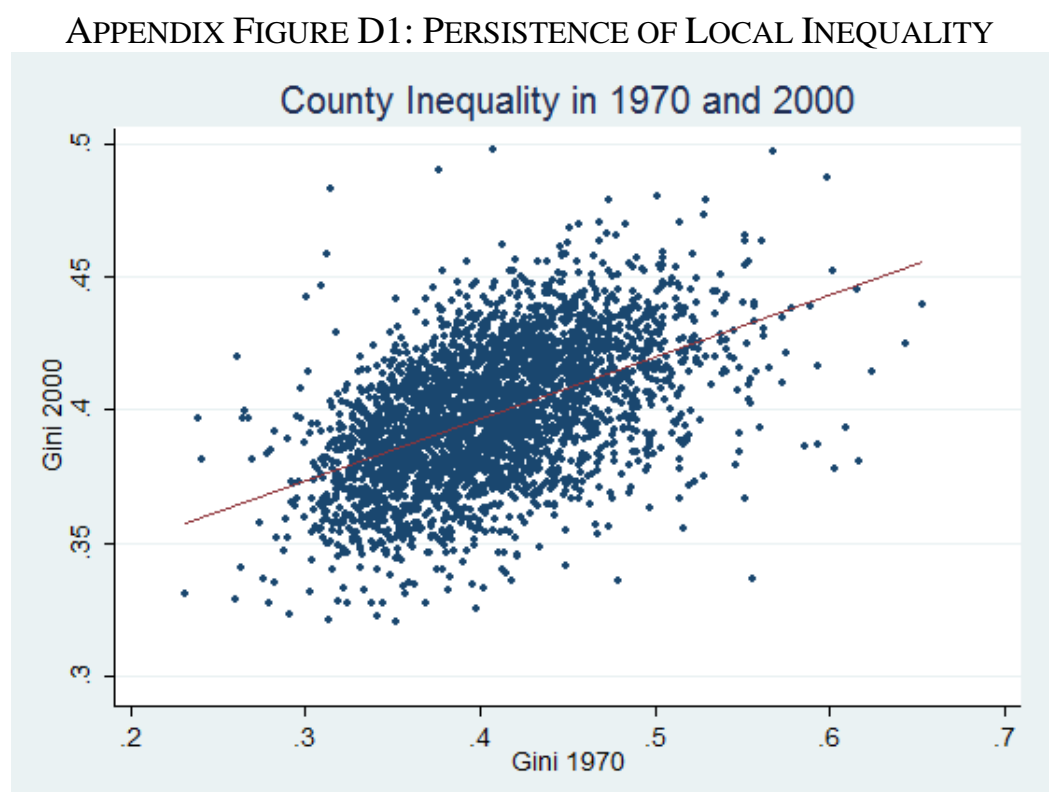

Note: The figure plots Gini coefficients for income inequality in U.S counties in 1970 versus 2000 . 


\section{APPENDIX E: SUMMARY STATISTICS FROM HMDA DATA}

Table 1 in this appendix provides summary statistics from the 15\% HMDA samples. We report the fraction of applications denied, originated, for owner-occupied properties, high interest, the race of the primary applicant, and the regulator of the lender. When using the HMDA data it is important to recognize that changes in reporting requirements from 2003 to 2004 had significant effects on the coverage of the mortgage market and so statistics we calculate. This can be seen clearly when comparing the change in racial composition of applicants from 2003 to 2004. While some of this might reflect real shifts in the provision of credit to non-white groups it also reflects the increased coverage of rural areas and smaller, non-bank lenders. This can also be seen by the large increase in applications filed at lenders regulated by HUD. While mortgage company activity was almost certainly increasing over this period many lenders were simply not reporting in the HMDA data.

The health of the mortgage market can be traced out by changes in the sample size. The number of applications reported peaked in 2007 and then declined steadily until 2011. Interestingly, the fraction of loans with high interest rates has also declined sharply, probably reflecting fewer loans with junior liens.

Notice that the mean applicant income reported in the HMDA data is substantially higher than the average household income reported in the SCF data and the imputed CCP data. However, average income is comparable to the average income of homeowners as reported in the 2007 SCF, which is about $\$ 99,500$.

Table 2 provides some sample correlations from 2007, most of which are qualitatively similar to other years. Owner-occupied applications are less likely to be denied while applications with high LTI ratios are more likely to be denied. Applicants applying to HUD-regulated lenders are more likely to be denied, which could reflect the stress of mortgage companies in this period or an increased likelihood that the applicant is subprime. Applicants to HUD lenders tend to have smaller incomes and higher LTI ratios. 
APPENDIX TABLE E1: SUMMARY STATISTICS FROM HMDA

\begin{tabular}{|c|c|c|c|c|c|c|c|c|c|c|c|}
\hline & 2001 & 2002 & 2003 & 2004 & 2005 & 2006 & 2007 & 2008 & 2009 & 2010 & 2011 \\
\hline Denied & 0.15 & 0.13 & 0.13 & 0.15 & 0.16 & 0.18 & 0.18 & 0.17 & 0.14 & 0.15 & 0.15 \\
\hline Originated & 0.78 & 0.79 & 0.78 & 0.76 & 0.72 & 0.71 & 0.72 & 0.73 & 0.76 & 0.75 & 0.75 \\
\hline OOC & 0.94 & 0.93 & 0.92 & 0.90 & 0.88 & 0.90 & 0.91 & 0.92 & 0.94 & 0.94 & 0.93 \\
\hline LTI & 2.31 & 2.43 & 2.58 & 2.65 & 2.67 & 2.63 & 2.72 & 2.72 & 2.81 & 2.79 & 2.70 \\
\hline sd & 0.88 & 0.94 & 1.03 & 1.08 & 1.08 & 1.04 & 1.11 & 1.10 & 1.12 & 1.12 & 1.10 \\
\hline Loan & 140.16 & 154.40 & 168.24 & 193.11 & 212.85 & 223.00 & 226.41 & 207.03 & 198.34 & 203.31 & 200.69 \\
\hline sd & 96.03 & 104.30 & 111.90 & 147.30 & 165.15 & 173.16 & 180.86 & 155.68 & 141.21 & 148.88 & 151.88 \\
\hline Income & 64.84 & 68.46 & 70.72 & 78.13 & 85.41 & 91.21 & 91.01 & 84.15 & 78.02 & 80.84 & 82.38 \\
\hline sd & 47.46 & 49.75 & 50.95 & 63.29 & 70.48 & 76.46 & 81.55 & 73.44 & 65.42 & 68.73 & 71.28 \\
\hline High Int & & & & 0.08 & 0.16 & 0.16 & 0.08 & 0.06 & 0.04 & 0.02 & 0.03 \\
\hline White & 0.89 & 0.88 & 0.88 & 0.74 & 0.71 & 0.69 & 0.73 & 0.76 & 0.76 & 0.76 & 0.77 \\
\hline Black & 0.08 & 0.07 & 0.08 & 0.08 & 0.10 & 0.11 & 0.10 & 0.08 & 0.07 & 0.07 & 0.07 \\
\hline OCC & 0.28 & 0.27 & 0.26 & 0.23 & 0.20 & 0.23 & 0.32 & 0.32 & 0.29 & 0.31 & 0.06 \\
\hline FRS & 0.11 & 0.18 & 0.18 & 0.15 & 0.16 & 0.16 & 0.17 & 0.09 & 0.09 & 0.08 & 0.04 \\
\hline FDIC & 0.09 & 0.08 & 0.07 & 0.07 & 0.06 & 0.06 & 0.06 & 0.09 & 0.11 & 0.11 & 0.09 \\
\hline OTS & 0.11 & 0.10 & 0.09 & 0.08 & 0.09 & 0.08 & 0.10 & 0.08 & 0.06 & 0.05 & 0.00 \\
\hline NCUA & 0.02 & 0.02 & 0.02 & 0.02 & 0.02 & 0.02 & 0.03 & 0.05 & 0.04 & 0.04 & 0.04 \\
\hline HUD & 0.39 & 0.36 & 0.38 & 0.45 & 0.47 & 0.45 & 0.33 & 0.36 & 0.40 & 0.41 & 0.43 \\
\hline
\end{tabular}

Note: The table provides sample means for all variables and standard deviations for continuous variables for all years of the HMDA data under the sample restrictions identified in the text. Denied gives the probability that an application was formally denied while originated gives the probability a loan was approved and the funds disbursed to the borrower. OOC indicates that the application is for an owner-occupied home. LTI is the loan-to-income ratio on the application constructed from the application's stated loan and income. High Int indicates if a loan was ultimately originated as a high interest loan. While and black both refer to the race of the primary applicant. OCC indicates a loan filed at a lender regulated by the Office of the Comptroller of the Currency. Similarly, FRS indicates a lender regulated by the Federal Reserve System, OTS regulated by the Office of Thrift Supervision, NCUA the National Credit Union Administration, and HUD the Department of Housing and Urban Development. 
APPENDIX TABLE E2: SAMPLE CORRELATIONS FROM 2007 HMDA

\begin{tabular}{|c|c|c|c|c|c|c|c|c|}
\hline & Denied & Originated & $\mathrm{OOC}$ & LTI & Loan & Inc & White & Black \\
\hline Denied & 1.000 & & & & & & & \\
\hline Originated & $-0.762 * * *$ & 1.000 & & & & & & \\
\hline OOC & $-0.0192 * * *$ & $0.021^{* * *}$ & 1.000 & & & & & \\
\hline LTI & $0.053^{* * *}$ & $-0.060 * * *$ & $0.200 * * *$ & 1.000 & & & & \\
\hline Loan & 0.001 & $-0.020 * * *$ & $-0.0308 * * *$ & $0.208^{* * *}$ & 1.000 & & & \\
\hline Income & $-0.028 * * *$ & $0.014^{* * *}$ & $-0.169 * * *$ & $-0.238 * * *$ & $0.815^{* * *}$ & 1.000 & & \\
\hline White & $-0.145^{* * *}$ & $0.146 * * *$ & $-0.0105^{* * *}$ & $-0.116^{* * *}$ & $-0.033^{* * *}$ & $0.034^{* * *}$ & 1.000 & \\
\hline Black & $0.116^{* * *}$ & $-0.113 * * *$ & $0.007 * * *$ & $0.050 * * *$ & $-0.053 * * *$ & $-0.074 * * *$ & $-0.545^{* * *}$ & 1.000 \\
\hline OCC & $-0.066^{* * *}$ & $0.120^{* * *}$ & $-0.005^{* * *}$ & $-0.012^{* * *}$ & $0.056^{* * *}$ & $0.063^{* * *}$ & $0.006^{* * *}$ & $-0.025 * * *$ \\
\hline FRS & $0.051^{* * *}$ & $-0.070 * * *$ & -0.002 & $-0.022 * * *$ & $-0.023^{* * *}$ & $-0.011 * * *$ & 0.001 & $0.004 * *$ \\
\hline FDIC & $-0.044 * * *$ & $0.045^{* * *}$ & $-0.031 * * *$ & $-0.031 * * *$ & $-0.060 * * *$ & $-0.041 * * *$ & $0.078 * * *$ & $-0.037 * * *$ \\
\hline OTS & $0.0547 * * *$ & $-0.009 * * *$ & $-0.022 * * *$ & $-0.003^{*}$ & $0.081 * * *$ & $0.070^{* * *}$ & $-0.027 * * *$ & $0.006^{* * *}$ \\
\hline NCUA & $-0.025 * * *$ & $0.008 * * *$ & $0.029 * * *$ & $-0.004^{* *}$ & $-0.042 * * *$ & $-0.040 * * *$ & $0.039 * * *$ & $-0.020 * * *$ \\
\hline HUD & $0.022 * * *$ & $-0.084 * * *$ & $0.026 * * *$ & $0.048^{* * *}$ & $-0.042 * * *$ & $-0.062 * * *$ & $-0.044^{* * *}$ & $0.044^{* * *}$ \\
\hline
\end{tabular}

Note: The table provides correlations for all years of the HMDA data under the sample restrictions identified in the text. Denied gives the probability that an application was formally denied while originated gives the probability a loan was approved and the funds disbursed to the borrower. OOC indicates that the application is for an owner-occupied home. LTI is the loan-to-income ratio on the application constructed from the application's stated loan and income. High Int indicates if a loan was ultimately originated as a high interest loan. White and black both refer to the race of the primary applicant. OCC indicates a loan filed at a lender regulated by the Office of the Comptroller of the Currency. Similarly, FRS indicates a lender regulated by the Federal Reserve System, OTS regulated by the Office of Thrift Supervision, NCUA the National Credit Union Administration, and HUD the Department of Housing and Urban Development. 


\section{APPENDIX F: INCOME AND DEFAULT}

We use the CCP data to verify our assumption about probability of default conditional on income. In particular, we estimate a linear probability model of the probability of default as a function of household income.

The dependent variable takes value 1 if any member of the household in year $t$ is 60-day past due or longer on any account (mortgage, auto loan, credit card, etc.). The explanatory variable of interest is the (log of the) household income in year 2001 (using the expected imputed income). We first estimate a parsimonious specification with only the income measure. We then estimate a specification with the measure of income and the full set of household and regional controls. These household-level controls are the following variables measured at 2001: dummies for age of the head of household and for the size of the household; amount of mortgage, auto loan, credit card balance, credit card limit, HELOC, student loan; dummies for bankruptcy and 60 DPD or longer, and risk score. The regional-level controls are the following zip code-level variables measured in 2001: income inequality, median of total household debt, median of household mortgage, house price growth between 2001 and year $t$, the ratio of the median house price to the median income, and the county level fixed effects. In the estimation, the standard errors are clustered by zip code. We use a linear probability model since the mean of the dependent variable is in the range $0.25-0.30$. The equation is estimated for each year from 2002 to 2012 for the sample of the households use in the benchmark regression of our analysis (i.e., the households that do not change location between year 2001 and year $t$ ).

We report results in Appendix Table E1. We find that higher-income households and households with higher income ranks have lower probability of default. 
Appendix Table F1. Income and default.

\begin{tabular}{|c|c|c|c|c|c|c|c|c|c|c|c|}
\hline & 2002 & 2003 & 2004 & 2005 & 2006 & 2007 & 2008 & 2009 & 2010 & 2011 & 2012 \\
\hline rank & $\begin{array}{c}-0.387 * * * \\
(0.00181)\end{array}$ & $\begin{array}{c}-0.337 * * * \\
(0.00184)\end{array}$ & $\begin{array}{c}-0.347 * * * \\
(0.00186)\end{array}$ & $\begin{array}{c}-0.314 * * * \\
(0.00182)\end{array}$ & $\begin{array}{r}P a r \\
-0.294 * * * \\
(0.00179)\end{array}$ & $\begin{array}{l}\text { A: No Cont } \\
-0.264 * * * \\
(0.00179)\end{array}$ & $\begin{array}{l}l s \\
\qquad-0.244^{* * *} \\
(0.00180)\end{array}$ & $\begin{array}{l}-0.219 * * * \\
(0.00183)\end{array}$ & $\begin{array}{l}-0.206 * * * \\
(0.00185)\end{array}$ & $\begin{array}{c}-0.199 * * * \\
(0.00188)\end{array}$ & $\begin{array}{c}-0.205^{* * *} \\
(0.00191)\end{array}$ \\
\hline $\begin{array}{l}N \\
R^{2} \\
\end{array}$ & $\begin{array}{c}6,172,512 \\
0.029 \\
\end{array}$ & $\begin{array}{c}5,676,766 \\
0.022 \\
\end{array}$ & $\begin{array}{c}5,039,109 \\
0.023 \\
\end{array}$ & $\begin{array}{c}4,570,211 \\
0.019 \\
\end{array}$ & $\begin{array}{c}4,218,948 \\
0.017 \\
\end{array}$ & $\begin{array}{c}3,950,618 \\
0.014 \\
\end{array}$ & $\begin{array}{c}3,731,267 \\
0.012 \\
\end{array}$ & $\begin{array}{c}3,581,280 \\
0.010 \\
\end{array}$ & $\begin{array}{c}3,433,201 \\
0.008 \\
\end{array}$ & $\begin{array}{c}3,310,773 \\
0.008 \\
\end{array}$ & $\begin{array}{c}3,197,351 \\
0.008 \\
\end{array}$ \\
\hline rank & $\begin{array}{c}-0.385^{* * *} \\
(0.00184)\end{array}$ & $\begin{array}{c}-0.335^{* * *} \\
(0.00186)\end{array}$ & $\begin{array}{c}-0.345^{* * *} \\
(0.00189)\end{array}$ & $\begin{array}{c}-0.312 * * * \\
(0.00184)\end{array}$ & $\begin{array}{c}\text { Panel E } \\
-0.293^{* * *} \\
(0.00179)\end{array}$ & $\begin{array}{c}\text { County Fixe } \\
-0.263^{* * *} \\
(0.00178)\end{array}$ & $\begin{array}{l}\text { Effects } \\
-0.245^{* * *} \\
(0.00177)\end{array}$ & $\begin{array}{c}-0.220 * * * \\
(0.00180)\end{array}$ & $\begin{array}{c}-0.208 * * * \\
(0.00180)\end{array}$ & $\begin{array}{c}-0.201^{* * *} \\
(0.00183)\end{array}$ & $\begin{array}{c}-0.208 * * * \\
(0.00186)\end{array}$ \\
\hline $\begin{array}{l}N \\
R^{2} \\
\end{array}$ & $\begin{array}{c}6,172,512 \\
0.058\end{array}$ & $\begin{array}{c}5,676,766 \\
0.051 \\
\end{array}$ & $\begin{array}{c}5,039,109 \\
0.055\end{array}$ & $\begin{array}{c}4,570,211 \\
0.051\end{array}$ & $\begin{array}{c}4,218,948 \\
0.048\end{array}$ & $\begin{array}{c}3,950,618 \\
0.043 \\
\end{array}$ & $\begin{array}{c}3,731,267 \\
0.039 \\
\end{array}$ & $\begin{array}{c}3,581,280 \\
0.035\end{array}$ & $\begin{array}{c}3,433,201 \\
0.034 \\
\end{array}$ & $\begin{array}{c}3,310,773 \\
0.033 \\
\end{array}$ & $\begin{array}{c}3,197,351 \\
0.033 \\
\end{array}$ \\
\hline rank & $\begin{array}{c}-0.0381 * * * \\
(0.00168)\end{array}$ & $\begin{array}{c}-0.0422^{* * * *} \\
(0.00189)\end{array}$ & $\begin{array}{c}-0.0443^{* * *} \\
(0.00209)\end{array}$ & $\begin{array}{c}\text { Panel C: Hc } \\
-0.0489^{* * *} \\
(0.00221)\end{array}$ & $\begin{array}{c}\text { sehold-specifi } \\
-0.0521^{* * *} \\
(0.00230)\end{array}$ & $\begin{array}{c}\text { Characterist } \\
-0.0458^{* * *} \\
(0.00245)\end{array}$ & $\begin{array}{c}\text { and County } \\
-0.0288^{* * *} \\
(0.00251)\end{array}$ & $\begin{array}{c}\text { ixed Effects } \\
-0.0083^{* * *} \\
(0.00260)\end{array}$ & $\begin{array}{c}0.00125 \\
(0.00268)\end{array}$ & $\begin{array}{c}0.00724 * * * \\
(0.00270)\end{array}$ & $\begin{array}{c}0.0146 * * * \\
(0.00276)\end{array}$ \\
\hline $\begin{array}{l}N \\
R^{2} \\
\end{array}$ & $\begin{array}{c}4,195,007 \\
0.460 \\
\end{array}$ & $\begin{array}{c}3,836,566 \\
0.359 \\
\end{array}$ & $\begin{array}{c}3,380,052 \\
0.326 \\
\end{array}$ & $\begin{array}{c}3,047,381 \\
0.274 \\
\end{array}$ & $\begin{array}{c}2,803,886 \\
0.244 \\
\end{array}$ & $\begin{array}{c}2,619,591 \\
0.213 \\
\end{array}$ & $\begin{array}{c}2,470,908 \\
0.187 \\
\end{array}$ & $\begin{array}{c}2,367,350 \\
0.177 \\
\end{array}$ & $\begin{array}{c}2,265,545 \\
0.171 \\
\end{array}$ & $\begin{array}{c}2,182,951 \\
0.161 \\
\end{array}$ & $\begin{array}{c}2,105,700 \\
0.159 \\
\end{array}$ \\
\hline $\ln (y)$ & $\begin{array}{c}-0.163^{* * *} \\
(0.000620)\end{array}$ & $\begin{array}{c}-0.149 * * * \\
(0.000600)\end{array}$ & $\begin{array}{c}-0.157 * * * \\
(0.000621)\end{array}$ & $\begin{array}{c}-0.147 * * * \\
(0.000627)\end{array}$ & $\begin{array}{c}\text { Panel D } \\
-0.142^{* * *} \\
(0.000634)\end{array}$ & $\begin{array}{c}\text { No Controls } \\
-0.131^{* * *} \\
(0.000632)\end{array}$ & $\begin{array}{c}-0.122^{* * *} \\
(0.000649)\end{array}$ & $\begin{array}{c}-0.111^{* * *} \\
(0.000675)\end{array}$ & $\begin{array}{c}-0.105^{* * *} \\
(0.000697)\end{array}$ & $\begin{array}{c}-0.102^{* * *} \\
(0.000709)\end{array}$ & $\begin{array}{c}-0.105^{* * *} \\
(0.000730)\end{array}$ \\
\hline $\begin{array}{l}N \\
R^{2} \\
\end{array}$ & $\begin{array}{c}6,172,512 \\
0.049 \\
\end{array}$ & $\begin{array}{c}5,676,766 \\
0.041 \\
\end{array}$ & $\begin{array}{c}5,039,109 \\
0.045 \\
\end{array}$ & $\begin{array}{c}4,570,211 \\
0.041 \\
\end{array}$ & $\begin{array}{c}4,218,948 \\
0.038 \\
\end{array}$ & $\begin{array}{c}3,950,618 \\
0.033 \\
\end{array}$ & $\begin{array}{c}3,731,267 \\
0.029 \\
\end{array}$ & $\begin{array}{c}3,581,280 \\
0.023 \\
\end{array}$ & $\begin{array}{c}3,433,201 \\
0.021 \\
\end{array}$ & $\begin{array}{c}3,310,773 \\
0.020 \\
\end{array}$ & $\begin{array}{c}3,197,351 \\
0.021 \\
\end{array}$ \\
\hline $\ln (y)$ & $\begin{array}{c}-0.152^{* * *} \\
(0.000625)\end{array}$ & $\begin{array}{l}-0.136^{* * *} \\
(0.000616)\end{array}$ & $\begin{array}{c}-0.143^{* * *} \\
(0.000633)\end{array}$ & $\begin{array}{c}-0.133^{* * *} \\
(0.000626)\end{array}$ & $\begin{array}{c}\text { Panel E: Co } \\
-0.127^{* * *} \\
(0.000619)\end{array}$ & $\begin{array}{c}\text { aty Fixed Eff } \\
-0.117^{* * *} \\
(0.000611)\end{array}$ & $\begin{array}{l}\text { ts } \\
-0.111^{* * *} \\
(0.000615)\end{array}$ & $\begin{array}{c}-0.102^{* * *} \\
(0.000632)\end{array}$ & $\begin{array}{c}-0.0972 * * * \\
(0.000635)\end{array}$ & $\begin{array}{c}-0.0943 * * * \\
(0.000640)\end{array}$ & $\begin{array}{c}-0.0977 * * * \\
(0.000654)\end{array}$ \\
\hline $\begin{array}{l}N \\
R^{2} \\
\end{array}$ & $\begin{array}{c}6,172,512 \\
0.070 \\
\end{array}$ & $\begin{array}{c}5,676,766 \\
0.062 \\
\end{array}$ & $\begin{array}{c}5,039,109 \\
0.067 \\
\end{array}$ & $\begin{array}{c}4,570,211 \\
0.062 \\
\end{array}$ & $\begin{array}{c}4,218,948 \\
0.059\end{array}$ & $\begin{array}{c}3,950,618 \\
0.053 \\
\end{array}$ & $\begin{array}{c}3,731,267 \\
0.049 \\
\end{array}$ & $\begin{array}{c}3,581,280 \\
0.043 \\
\end{array}$ & $\begin{array}{c}3,433,201 \\
0.042 \\
\end{array}$ & $\begin{array}{c}3,310,773 \\
0.040\end{array}$ & $\begin{array}{c}3,197,351 \\
0.041\end{array}$ \\
\hline $\ln (y)$ & $\begin{array}{c}-0.0107 * * * \\
(0.000599)\end{array}$ & $\begin{array}{c}-0.0115^{* * *} \\
(0.000676)\end{array}$ & $\begin{array}{r}P \\
-0.0128 * * * \\
(0.000742)\end{array}$ & $\begin{array}{l}\text { el F: Househ } \\
-0.0147^{* * *} \\
(0.000789)\end{array}$ & $\begin{array}{c}d \text {-specific Ch } \\
-0.0161^{* * *} \\
(0.000820)\end{array}$ & $\begin{array}{r}\text { acteristics a } \\
-0.0138^{* * *} \\
(0.000873)\end{array}$ & $\begin{array}{c}\text { County Fixed } \\
-0.0081^{* * *} \\
(0.000895)\end{array}$ & $\begin{array}{l}\text { Effects } \\
\quad-0.00102 \\
(0.000936)\end{array}$ & $\begin{array}{l}0.00211^{* *} \\
(0.000966)\end{array}$ & $\begin{array}{c}0.00425^{* * *} \\
(0.000974)\end{array}$ & $\begin{array}{c}0.00649 * * * \\
(0.00100)\end{array}$ \\
\hline $\begin{array}{l}N \\
R^{2}\end{array}$ & $\begin{array}{c}4,195,007 \\
0.460\end{array}$ & $\begin{array}{c}3,836,566 \\
0.359\end{array}$ & $\begin{array}{c}3,380,052 \\
0.326\end{array}$ & $\begin{array}{c}3,047,381 \\
0.274\end{array}$ & $\begin{array}{c}2,803,886 \\
0.244\end{array}$ & $\begin{array}{c}2,619,591 \\
0.213\end{array}$ & $\begin{array}{c}2,470,908 \\
0.187\end{array}$ & $\begin{array}{c}2,367,350 \\
0.177\end{array}$ & $\begin{array}{c}2,265,545 \\
0.171\end{array}$ & $\begin{array}{c}2,182,951 \\
0.161\end{array}$ & $\begin{array}{c}2,105,700 \\
0.159\end{array}$ \\
\hline
\end{tabular}

Note: The table reports estimated coefficients on income rank (Panels A-C) and log income (Panels D-F) in the linear regression where the dependent variable is a dummy variable equal to one if a household defaults in a given year and zero otherwise. Standard errors (clustered by zip code) are reported in parentheses. $* * *, * *, *$ denote statistical significance at $1 \%, 5 \%$ and $10 \%$. 


\section{APPENDIX G: IMPUTATION OF INCOME}

In the first step of our work, we estimate the relationship between income and observables in the SCF and then use this relationship to impute income in the CCP. In this appendix, we describe how variables are constructed and what specification is estimated.

In the table below, we describe how variables are constructed in CCP and SCF. We use only variables which are available in both CCP and SCF. While there are some differences in the definitions across datasets, we made every effort to make it as comparable as possible.

\begin{tabular}{|c|c|c|}
\hline Variable & SCF & Counterpart in CCP \\
\hline Auto loans & $\begin{array}{l}\text { X2218 + X2318 + X2418 + } \\
\text { X7169 + X2424 + X2507 + } \\
\text { X2607 }\end{array}$ & $\begin{array}{l}\text { Auto loan bank and auto } \\
\text { loan finance balance }\end{array}$ \\
\hline Bankruptcy flag & X6772 & $\begin{array}{l}\text { Chapter } 7 \text { or Chapter } 13 \\
\text { bankruptcy flag }\end{array}$ \\
\hline Credit Card Limit ${ }^{30}$ & $\mathrm{X} 414$ & $\begin{array}{l}\text { Bank card + retail card } \\
\text { high credit }\end{array}$ \\
\hline Credit Card Balance & $\begin{array}{l}\text { X413+X427+ X421 + X424 } \\
+ \text { X430 }\end{array}$ & $\begin{array}{l}\text { Bank card + retail card } \\
\text { balance }\end{array}$ \\
\hline Delinquency flag & X3005 & $\begin{array}{l}\text { A flag if any account is } \\
60 \text { DPD or more }\end{array}$ \\
\hline HELOC Balance & $\begin{array}{l}\text { X1108 + X1119 + X1130+ } \\
\text { X1136 }\end{array}$ & $\begin{array}{l}\text { Home equity revolving } \\
\text { balance }\end{array}$ \\
\hline Income & X5729 & None \\
\hline Mortgage Debt & X805 + X905 + X1005 & $\begin{array}{l}\text { First mortgage balance } \\
+\quad \text { home equity } \\
\text { installment balance }\end{array}$ \\
\hline Student Loans & $\begin{array}{l}\text { X7824 + X7847 + } \\
\text { X7870 + X7924 + } \\
\text { X7947 + X7970 }\end{array}$ & Student loans balance \\
\hline
\end{tabular}

We also use household size and head of household age. The CCP does not include racial identifiers so we do not use these. In our imputation, we use all of the SCF replicates, which are discussed in detail by Kennickell (1998). Because the SCF intentionally oversamples wealthy households, we apply the SCF-computed weights X42001. Note that we take the natural log of one plus the level for all continuous variables to make the distribution of these variables more well-behaved and to avoid dropping observations with zero values. We also restrict the sample to households where the head's age was between 20 and 65. We dropped outliers using Cook's distance.

As discussed in the text, our regression has the general form

$$
\log \left(Y_{i, S C F}\right)=\beta f\left(X_{i, S C F}\right)+\epsilon_{i, S C F} .
$$

In choosing the specific form of $f$, we aimed to capture as much of joint distribution of the observables and income as we could with a flexible assumption. Terms were added if it was found that they were meaningful predictors of log income. Households with missing values are dropped, although results are essentially the same if we keep them and add one before taking logs. The function $f$ was composed of

\footnotetext{
${ }^{30}$ We code responses of "no limit” in the SCF as 1,000,000.
} 
1. Third-order Chebychev polynomials of mortgage, auto, and credit card limits,

2. Credit card, HELOC, and student loan balances,

3. Nine age bins in five year intervals,

4. Interactions of all age bins with each type of debt balance,

5. Household size and interactions of household size with debt balances and age bins,

6. Indicators for bankruptcy and delinquency and interactions of these indicators with other indicators,

7. Indicators for positive credit card limit and interactions of this variable with various variables,

8. Interactions of household size, age, and debt levels.

Table 2 shows that using data from 2001 the aggregate income statistics computed directly from the SCF match those we impute in the CCP very closely. 


\section{APPENDIX H: EMPIRICAL RESULTS USING INCOME FROM THE EQUIFAX CREDIT RISK INSIGHT SERVICING MCDASH (CRISM) DATASET}

\section{H.1. Data Description}

In this section, we replicate the empirical results using the measure of income available in the Equifax Credit Risk Servicing McDash (CRISM) Dataset as opposed to the imputed income that we use in the main analysis in the paper.

CRISM dataset contains Equifax credit bureau data on individual consumers' credit histories matched to the mortgage-level McDash servicing data. Consequently, CRISM contains information on credit borrowers with a mortgage. Updated monthly, with coverage beginning in June 2005, CRISM is constructed by using a proprietary and confidential matching process in which Equifax uses anonymous fields such as original and current mortgage balance, origination date, zip code, and payment history to match each loan in the McDash dataset to a particular consumer's tradeline in the Equifax.

Within the CRISM dataset, our variable of interest is the income variable, Personal Income Model (PIM). Based on a large, national sample of employer-provided, known incomes, PIM is developed using Equifax's national consumer credit database, and predicts income at an individual level. It estimates an individual's income and then returns a specific three-digit income value (ranging from 1-999), representing the individual's annual income in thousands.

Since the CRISM dataset is available starting from June 2005, we use year 2005 as the base year for replication of the main empirical results rather than year 2001. Since the CCP dataset is quarterly while the CRISM dataset is monthly, we use September of 2005 from the CRISM dataset to match to 2005Q3 in the CCP dataset.

\section{H.2. Results}

We then replicate the benchmark results in Table 3 using the income variable (PIM) from CRISM. In the construction of the household's income rank, we obtain the relative rank within a zip code directly instead of utilizing bootstrap procedure. We relax the minimum number of households needed to construct rank in a given zip code from 100 to 30, and in a given county from 300 to 100. We also use PIM to construct the inequality variable as discussed in the main text.

Table H.1 contains summary statistics of the income measure from CRISM. As can be seen, the mean is higher and the standard deviation is lower than of the income from the SCF in Table 2. This could be due to the fact that only borrowers with mortgages are included in the CRISM dataset. Figure H.1 shows the results.

Table H.2 shows the results from estimating the regression of the debt accumulation between 2005 and the following years (relative to the household's income in 2005) on the household's income rank in 2005, local inequality in 2005 and the interaction of the two as described in eq. 2. The income rank and inequality are constructed at a zip-code level. The table replicates four specifications in Table 3. As can be seen from the specifications with controls (Panels B, C, D) the main results carry through. The only exception is the specification without controls (Panel A): the coefficients on the inequality and on the interaction of inequality with income rank in the specification without controls change signs as compared to the results in Table 3; these coefficients are also not statistically significant after 2009.

Table H.3 shows the results from estimating the specifications similar to the ones in table H.2 but with actual income level rather than income rank as the explanatory variable. The results from Table H.2 carry through.

Table H.4 replicates table H.2 but with county-level income rank and inequality measures. All results from table H.2 carry through. (Table 6, Panel A shows the specification with the full set of controls, Panel C.)

Finally, Table H.5 shows the results with the inverse of the expected income instead of the income rank (Panel A) and with the outcome expressed as the log of the difference between debt in 2005 and the debt in a subsequent year (Panel B). All the main results carry through (the corresponding table is A2 in the appendix). 
TABLE H.1: INCOME STATISTICS FROM SCF (ACTUAL) AND CRISM, \$2005

\begin{tabular}{lccrrrrr}
\hline & \multirow{2}{*}{ Mean } & St. dev. & \multicolumn{5}{c}{ Percentiles } \\
\cline { 4 - 8 } & & & 10 & 25 & 50 & 75 & 90 \\
\hline \hline & & & & & & & \\
Ln(Y), pim in CRISM & 11.27 & 0.60 & 10.49 & 10.90 & 11.34 & 11.67 & 11.95 \\
\hline \hline
\end{tabular}

Note: The sample is restricted to households with the 20-65 y.o. head of household and positive gross income. 
TABLE H.2: BASELINE Results ON HOUSEHOLD DEBT ACCUMULATION, 2005 - ONWARDS USING INCOME FROM CRISM, ZIP CODE-LEVEL INEQUALITY

\begin{tabular}{|c|c|c|c|c|c|c|c|}
\hline & 2006 & 2007 & 2008 & 2009 & 2010 & 2011 & 2012 \\
\hline \multirow{3}{*}{$\alpha$} & \multicolumn{7}{|c|}{ Panel A: Parsimonious Specification } \\
\hline & $-0.479 * * *$ & $-0.492 * * *$ & $-0.458^{* * *}$ & $-0.460 * * *$ & $-0.416^{* * *}$ & $-0.310^{* * *}$ & $-0.235 * * *$ \\
\hline & $(0.0288)$ & $(0.0374)$ & $(0.0389)$ & $(0.0417)$ & $(0.0437)$ & $(0.0444)$ & $(0.0456)$ \\
\hline \multirow[t]{2}{*}{$\beta$} & $0.104^{* * *}$ & $0.156^{* * *}$ & $0.152 * * *$ & $0.123 * * *$ & 0.0371 & -0.00420 & $-0.0583 * *$ \\
\hline & $(0.0177)$ & $(0.0226)$ & $(0.0232)$ & $(0.0246)$ & $(0.0252)$ & $(0.0255)$ & $(0.0262)$ \\
\hline \multirow[t]{2}{*}{$\gamma$} & $-0.0510 * *$ & $-0.156 * * *$ & $-0.161 * * *$ & $-0.136 * * *$ & -0.0624 & $-0.0685^{*}$ & -0.0484 \\
\hline & $(0.0249)$ & $(0.0326)$ & $(0.0337)$ & $(0.0362)$ & $(0.0380)$ & $(0.0385)$ & $(0.0394)$ \\
\hline$N$ & $1,515,494$ & $1,398,594$ & $1,314,108$ & $1,256,436$ & $1,201,184$ & $1,154,719$ & $1,111,231$ \\
\hline \multirow[t]{2}{*}{$R^{2}$} & 0.037 & 0.045 & 0.041 & 0.034 & 0.022 & 0.017 & 0.014 \\
\hline & \multicolumn{7}{|c|}{ Panel B: Specification with Household Controls } \\
\hline \multirow[t]{2}{*}{$\alpha$} & $-0.476^{* * *}$ & $-0.466 * * *$ & $-0.426^{* * *}$ & $-0.444 * * *$ & $-0.428 * * *$ & $-0.342 * * *$ & $-0.290 * * *$ \\
\hline & $(0.0269)$ & $(0.0352)$ & $(0.0360)$ & $(0.0382)$ & $(0.0398)$ & $(0.0395)$ & $(0.0405)$ \\
\hline \multirow[t]{2}{*}{$\beta$} & $-0.0712 * * *$ & $-0.0386^{*}$ & -0.0336 & $-0.0456 * *$ & $-0.114 * * *$ & $-0.147 * * *$ & $-0.198 * * *$ \\
\hline & $(0.0159)$ & $(0.0205)$ & $(0.0210)$ & $(0.0223)$ & $(0.0232)$ & $(0.0233)$ & $(0.0240)$ \\
\hline \multirow[t]{2}{*}{$\gamma$} & $0.274^{* * *}$ & $0.199 * * *$ & $0.184^{* * *}$ & $0.185^{* * *}$ & $0.233^{* * *}$ & $0.219 * * *$ & $0.235 * * *$ \\
\hline & $(0.0235)$ & $(0.0309)$ & $(0.0316)$ & $(0.0335)$ & $(0.0349)$ & $(0.0346)$ & $(0.0352)$ \\
\hline$N$ & $1,515,257$ & $1,398,167$ & $1,313,470$ & $1,255,442$ & $1,199,727$ & $1,152,689$ & $1,108,681$ \\
\hline \multirow[t]{2}{*}{$R^{2}$} & 0.221 & 0.197 & 0.190 & 0.166 & 0.144 & 0.141 & 0.138 \\
\hline & \multicolumn{7}{|c|}{ Panel C: Specification with Household and Zip-Level Controls } \\
\hline \multirow[t]{2}{*}{$\alpha$} & $-0.467 * * *$ & $-0.457 * * *$ & $-0.414 * * *$ & $-0.432 * * *$ & $-0.415^{* * *}$ & $-0.325^{* * *}$ & $-0.273 * * *$ \\
\hline & $(0.0269)$ & $(0.0351)$ & $(0.0360)$ & $(0.0382)$ & $(0.0398)$ & $(0.0395)$ & $(0.0405)$ \\
\hline \multirow[t]{2}{*}{$\beta$} & $-0.0981 * * *$ & $-0.0662 * * *$ & $-0.0520 * *$ & $-0.0554 * *$ & $-0.103^{* * *}$ & $-0.118 * * *$ & $-0.155^{* * *}$ \\
\hline & $(0.0156)$ & $(0.0203)$ & $(0.0208)$ & $(0.0222)$ & $(0.0229)$ & $(0.0229)$ & $(0.0236)$ \\
\hline \multirow[t]{2}{*}{$\gamma$} & $0.286^{* * *}$ & $0.208 * * *$ & $0.198 * * *$ & $0.200 * * *$ & $0.256^{* * *}$ & $0.250 * * *$ & $0.269 * * *$ \\
\hline & $(0.0235)$ & $(0.0309)$ & $(0.0316)$ & $(0.0335)$ & $(0.0349)$ & $(0.0346)$ & $(0.0353)$ \\
\hline$N$ & $1,515,257$ & $1,398,167$ & $1,313,470$ & $1,255,442$ & $1,199,727$ & $1,152,689$ & $1,108,681$ \\
\hline \multirow[t]{2}{*}{$R^{2}$} & 0.222 & 0.198 & 0.191 & 0.167 & 0.145 & 0.142 & 0.140 \\
\hline & \multicolumn{7}{|c|}{ Panel D: Specification with Zip-Level Fixed Effects } \\
\hline \multirow[t]{2}{*}{$\alpha$} & $-0.465 * * *$ & $-0.452 * * *$ & $-0.410 * * *$ & $-0.431 * * *$ & $-0.414 * * *$ & $-0.327 * * *$ & $-0.273 * * *$ \\
\hline & $(0.0427)$ & $(0.0690)$ & $(0.0727)$ & $(0.0697)$ & $(0.0651)$ & $(0.0627)$ & $(0.0674)$ \\
\hline \multirow[t]{2}{*}{$\gamma$} & $0.286 * * *$ & $0.205^{* * *}$ & $0.197 * * *$ & $0.201^{* * *}$ & $0.258 * * *$ & $0.255^{* * *}$ & $0.273 * * *$ \\
\hline & $(0.0390)$ & $(0.0652)$ & $(0.0648)$ & $(0.0622)$ & $(0.0624)$ & $(0.0576)$ & $(0.0559)$ \\
\hline$N$ & $1,515,257$ & 1,398,167 & $1,313,470$ & $1,255,442$ & $1,199,727$ & $1,152,689$ & $1,108,681$ \\
\hline$R^{2}$ & 0.229 & 0.205 & 0.199 & 0.175 & 0.154 & 0.151 & 0.150 \\
\hline
\end{tabular}

Note: The table presents estimates of specifications (2), (3), (4) and (5) in Panels A through D respectively. Coefficient $\alpha$ corresponds to the partial correlation of household income rank and debt accumulation between 2005 and the year indicated in each column (relative to household's 2005 income). Coefficient $\beta$ corresponds to the partial correlation of local inequality and household debt accumulation. Coefficient $\gamma$ is for the interaction of household income and local inequality. Each regression is run at the household level. Statistical significance at the $1 \%, 5 \%$, and $10 \%$ levels are indicated by $* * *, * *$, and * respectively. In Panels A-C, the standard errors are clustered by zip code; in Panel D, standard errors are clustered by state. See sections 3.1 and 3.2 in the text for details. 
TABLE H.3: RESULTS ON HOUSEHOLD DEBT ACCUMULATION USING INCOME LEVEL RATHER THAN INCOME RANK, 2005 - ONWARDS USING INCOME FROM CRISM, ZIP CODE-LEVEL INEQUALITY

\begin{tabular}{|c|c|c|c|c|c|c|c|}
\hline & 2006 & 2007 & 2008 & 2009 & 2010 & 2011 & 2012 \\
\hline \multirow[b]{2}{*}{$\alpha$} & \multicolumn{7}{|c|}{ Panel A: Parsimonious Specification } \\
\hline & $\begin{array}{c}-5.14 \mathrm{e}-06 * * * \\
(2.08 \mathrm{e}-07)\end{array}$ & $\begin{array}{c}-5.91 \mathrm{e}-06 * * * \\
(2.50 \mathrm{e}-07)\end{array}$ & $\begin{array}{c}-5.65 \mathrm{e}-06 * * * \\
(2.56 \mathrm{e}-07)\end{array}$ & $\begin{array}{c}-5.38 \mathrm{e}-06 * * * \\
(2.54 \mathrm{e}-07)\end{array}$ & $\begin{array}{c}-4.26 \mathrm{e}-06^{* * *} \\
(2.62 \mathrm{e}-07)\end{array}$ & $\begin{array}{c}-2.73 \mathrm{e}-06 * * * \\
(2.48 \mathrm{e}-07)\end{array}$ & $\begin{array}{c}-1.67 \mathrm{e}-06 * * * \\
(2.59 \mathrm{e}-07)\end{array}$ \\
\hline$\beta$ & $-0.125 * * *$ & $-0.128 * * *$ & $-0.128 * * *$ & $-0.135 * * *$ & $-0.148 * * *$ & $-0.108 * * *$ & $-0.103^{* * *}$ \\
\hline & $(0.0192)$ & $(0.0235)$ & $(0.0241)$ & $(0.0252)$ & $(0.0263)$ & $(0.0257)$ & $(0.0269)$ \\
\hline \multirow[t]{2}{*}{$\gamma$} & $1.88 \mathrm{e}-06^{* * *}$ & $1.83 \mathrm{e}-06^{* * *}$ & $1.76 \mathrm{e}-06^{* * *}$ & $1.67 e-06 * * *$ & $1.37 \mathrm{e}-06^{* * *}$ & $5.78 \mathrm{e}-07 * * *$ & $1.25 \mathrm{e}-07$ \\
\hline & $(1.72 \mathrm{e}-07)$ & (2.09e-07) & $(2.15 \mathrm{e}-07)$ & $(2.13 e-07)$ & $(2.21 \mathrm{e}-07)$ & $(2.08 \mathrm{e}-07)$ & $(2.18 \mathrm{e}-07)$ \\
\hline$N$ & $1,515,494$ & $1,398,594$ & $1,314,108$ & $1,256,436$ & $1,201,184$ & $1,154,719$ & $1,111,231$ \\
\hline$R^{2}$ & 0.031 & 0.040 & 0.036 & 0.030 & 0.020 & 0.015 & 0.012 \\
\hline & \multicolumn{7}{|c|}{ Panel B: Specification with Household Controls } \\
\hline$\alpha$ & $\begin{array}{c}-2.19 \mathrm{e}-06 * * * \\
(1.61 \mathrm{e}-07)\end{array}$ & $\begin{array}{c}-2.48 \mathrm{e}-06^{* * *} \\
(2.07 \mathrm{e}-07)\end{array}$ & $\begin{array}{c}-2.21 \mathrm{e}-06 * * * \\
(2.19 \mathrm{e}-07)\end{array}$ & $\begin{array}{c}-2.29 \mathrm{e}-06 * * * \\
(2.24 \mathrm{e}-07)\end{array}$ & $\begin{array}{c}-1.75 \mathrm{e}-06 * * * \\
(2.35 \mathrm{e}-07)\end{array}$ & $\begin{array}{c}-5.29 \mathrm{e}-07 * * \\
(2.30 \mathrm{e}-07)\end{array}$ & $\begin{array}{c}2.07 \mathrm{e}-07 \\
(2.44 \mathrm{e}-07)\end{array}$ \\
\hline$\beta$ & $-0.116^{* * *}$ & $-0.110^{* * *}$ & $-0.104 * * *$ & $-0.114 * * *$ & $-0.136^{* * *}$ & $-0.0993 * * *$ & $-0.101 * * *$ \\
\hline \multirow{3}{*}{$\gamma$} & $(0.0161)$ & $(0.0206)$ & $(0.0215)$ & $(0.0227)$ & $(0.0237)$ & $(0.0235)$ & $(0.0247)$ \\
\hline & $1.76 \mathrm{e}-06^{* * *}$ & $1.61 \mathrm{e}-06^{* * *}$ & $1.52 \mathrm{e}-06^{* * *}$ & $1.50 \mathrm{e}-06 * * *$ & $1.33 \mathrm{e}-06^{* * *}$ & $6.17 \mathrm{e}-07 * * *$ & $2.48 \mathrm{e}-07$ \\
\hline & $(1.34 \mathrm{e}-07)$ & $(1.74 \mathrm{e}-07)$ & $(1.85 \mathrm{e}-07)$ & $(1.89 \mathrm{e}-07)$ & $(1.99 \mathrm{e}-07)$ & $(1.93 \mathrm{e}-07)$ & $(2.04 \mathrm{e}-07)$ \\
\hline$N$ & $1,515,257$ & $1,398,167$ & $1,313,470$ & $1,255,442$ & $1,199,727$ & $1,152,689$ & $1,108,681$ \\
\hline$R^{2}$ & 0.220 & 0.195 & 0.189 & 0.165 & 0.144 & 0.141 & 0.139 \\
\hline \multicolumn{8}{|c|}{ Panel C: Specification with Household and Zip-Level Controls } \\
\hline$\alpha$ & $\begin{array}{c}-2.92 \mathrm{e}-06 * * * \\
(1.54 \mathrm{e}-07)\end{array}$ & $\begin{array}{c}-3.36 \mathrm{e}-06 * * * \\
(2.01 \mathrm{e}-07)\end{array}$ & $\begin{array}{c}-3.19 \mathrm{e}-06 * * * \\
(2.16 \mathrm{e}-07)\end{array}$ & $\begin{array}{c}-3.40 \mathrm{e}-06 * * * \\
(2.21 \mathrm{e}-07)\end{array}$ & $\begin{array}{c}-2.92 \mathrm{e}-06 * * * \\
(2.34 \mathrm{e}-07)\end{array}$ & $\begin{array}{c}-1.73 \mathrm{e}-06 * * * \\
(2.30 \mathrm{e}-07)\end{array}$ & $\begin{array}{c}-9.10 \mathrm{e}-07 * * * \\
(2.43 \mathrm{e}-07)\end{array}$ \\
\hline$\beta$ & $-0.139 * * *$ & $-0.129 * * *$ & $-0.117^{* * *}$ & $-0.120 * * *$ & $-0.129 * * *$ & $-0.0818^{* * *}$ & $-0.0746 * * *$ \\
\hline & $(0.0155)$ & $(0.0201)$ & $(0.0209)$ & $(0.0220)$ & $(0.0231)$ & $(0.0228)$ & $(0.0240)$ \\
\hline \multirow[t]{2}{*}{$\gamma$} & $1.97 e-06 * * *$ & $1.87 \mathrm{e}-06^{* * *}$ & $1.82 \mathrm{e}-06^{* * *}$ & $1.85 \mathrm{e}-06 * * *$ & $1.73 \mathrm{e}-06^{* * *}$ & $1.04 \mathrm{e}-06^{* * *}$ & $6.64 \mathrm{e}-07^{* * *}$ \\
\hline & $(1.28 \mathrm{e}-07)$ & $(1.70 \mathrm{e}-07)$ & $(1.81 \mathrm{e}-07)$ & $(1.85 e-07)$ & $(1.97 e-07)$ & $(1.92 \mathrm{e}-07)$ & $(2.01 \mathrm{e}-07)$ \\
\hline$N$ & $1,515,257$ & 1,398,167 & $1,313,470$ & $1,255,442$ & $1,199,727$ & $1,152,689$ & $1,108,681$ \\
\hline$R^{2}$ & 0.222 & 0.197 & 0.191 & 0.167 & 0.145 & 0.142 & 0.140 \\
\hline & \multicolumn{7}{|c|}{ Panel D: Specification with Zip-Level Fixed Effects } \\
\hline$\alpha$ & $\begin{array}{c}-4.03 \mathrm{e}-06^{* * *} \\
(2.92 \mathrm{e}-07)\end{array}$ & $\begin{array}{c}-4.78 \mathrm{e}-06 * * * \\
(3.80 \mathrm{e}-07)\end{array}$ & $\begin{array}{c}-4.39 \mathrm{e}-06 * * * \\
(4.25 \mathrm{e}-07)\end{array}$ & $\begin{array}{c}-4.57 \mathrm{e}-06^{* * *} \\
(3.95 \mathrm{e}-07)\end{array}$ & $\begin{array}{c}-3.81 \mathrm{e}-06 * * * \\
(3.83 \mathrm{e}-07)\end{array}$ & $\begin{array}{c}-2.60 \mathrm{e}-06 * * * \\
(4.76 \mathrm{e}-07)\end{array}$ & $\begin{array}{c}-1.72 \mathrm{e}-06 * * * \\
(5.98 \mathrm{e}-07)\end{array}$ \\
\hline$\gamma$ & 2.92e- $06 * * *$ & 3.09e- $06 * * *$ & $2.86 \mathrm{e}-06 * * *$ & $2.86 \mathrm{e}-06 * * *$ & $2.48 \mathrm{e}-06 * * *$ & $1.77 \mathrm{e}-06 * * *$ & $1.35 \mathrm{e}-06^{* * *}$ \\
\hline & & & & & & & \\
\hline$N$ & $1,515,257$ & $1,398,167$ & $1,313,470$ & $1,255,442$ & $1,199,727$ & $1,152,689$ & $1,108,681$ \\
\hline$R^{2}$ & 0.228 & 0.205 & 0.199 & 0.175 & 0.154 & 0.151 & 0.150 \\
\hline
\end{tabular}

Note: See note to Table H.2. 
TABle H.4: BASELine Results On HOUSEHOld DEBT ACCUMULATION, 2005 - ONWARDS USING INCOME FROM CRISM, COUNTY-LEVEL INEQUALITY

\begin{tabular}{|c|c|c|c|c|c|c|c|}
\hline & 2006 & 2007 & 2008 & 2009 & 2010 & 2011 & 2012 \\
\hline & \multicolumn{7}{|c|}{ Panel A: Parsimonious Specification } \\
\hline$\alpha$ & $\begin{array}{c}-0.572 * * * \\
(0.0887)\end{array}$ & $\begin{array}{c}-0.591 * * * \\
(0.178)\end{array}$ & $\begin{array}{c}-0.676 * * * \\
(0.188)\end{array}$ & $\begin{array}{c}-0.745^{* * *} \\
(0.200)\end{array}$ & $\begin{array}{c}-0.733 * * * \\
(0.175)\end{array}$ & $\begin{array}{c}-0.680 * * * \\
(0.164)\end{array}$ & $\begin{array}{c}-0.686 * * * \\
(0.162)\end{array}$ \\
\hline \multirow[t]{2}{*}{$\beta$} & $0.167 * * *$ & $0.290 * * *$ & $0.246 * *$ & $0.217^{* *}$ & 0.119 & 0.0576 & -0.0664 \\
\hline & $(0.0479)$ & $(0.0882)$ & $(0.0961)$ & $(0.108)$ & $(0.101)$ & $(0.0968)$ & $(0.0998)$ \\
\hline \multirow[t]{2}{*}{$\gamma$} & -0.0803 & -0.222 & -0.143 & -0.0593 & 0.0545 & 0.110 & 0.207 \\
\hline & $(0.0707)$ & $(0.142)$ & $(0.150)$ & $(0.160)$ & $(0.140)$ & $(0.130)$ & $(0.129)$ \\
\hline$N$ & $1,662,764$ & $1,571,626$ & $1,503,671$ & $1,457,806$ & $1,415,040$ & $1,378,848$ & $1,345,265$ \\
\hline \multirow[t]{2}{*}{$R^{2}$} & 0.040 & 0.049 & 0.045 & 0.037 & 0.023 & 0.016 & 0.011 \\
\hline & \multicolumn{7}{|c|}{ Panel B: Specification with Household Controls } \\
\hline$\alpha$ & $\begin{array}{c}-0.365 * * * \\
(0.0882)\end{array}$ & $\begin{array}{c}-0.335^{*} \\
(0.180)\end{array}$ & $\begin{array}{c}-0.442 * * \\
(0.179)\end{array}$ & $\begin{array}{c}-0.532 * * * \\
(0.175)\end{array}$ & $\begin{array}{c}-0.556 * * * \\
(0.137)\end{array}$ & $\begin{array}{c}-0.498 * * * \\
(0.117)\end{array}$ & $\begin{array}{c}-0.520 * * * \\
(0.107)\end{array}$ \\
\hline \multirow[t]{2}{*}{$\beta$} & $0.147 * * *$ & $0.260 * * *$ & $0.207^{* *}$ & $0.188^{*}$ & 0.105 & 0.0673 & -0.0474 \\
\hline & $(0.0477)$ & $(0.0889)$ & $(0.0930)$ & $(0.100)$ & $(0.0881)$ & $(0.0805)$ & $(0.0779)$ \\
\hline \multirow[t]{2}{*}{$\gamma$} & $0.145^{* *}$ & 0.0288 & 0.118 & 0.173 & $0.259 * *$ & $0.286 * * *$ & $0.377 * * *$ \\
\hline & $(0.0679)$ & $(0.141)$ & $(0.140)$ & $(0.138)$ & $(0.108)$ & $(0.0925)$ & $(0.0853)$ \\
\hline$N$ & $1,662,467$ & $1,571,086$ & $1,502,833$ & $1,456,525$ & $1,413,182$ & $1,376,196$ & $1,341,907$ \\
\hline \multirow[t]{2}{*}{$R^{2}$} & 0.230 & 0.205 & 0.195 & 0.170 & 0.150 & 0.147 & 0.145 \\
\hline & \multicolumn{7}{|c|}{ Panel C: Specification with Household and Zip-Level Controls } \\
\hline \multirow[t]{2}{*}{$\alpha$} & $-0.350 * * *$ & $-0.320 *$ & $-0.428 * *$ & $-0.519 * * *$ & $-0.545^{* * *}$ & $-0.487 * * *$ & $-0.510 * * *$ \\
\hline & $(0.0882)$ & $(0.179)$ & $(0.179)$ & $(0.175)$ & $(0.137)$ & $(0.117)$ & (0.108) \\
\hline \multirow[t]{2}{*}{$\beta$} & -0.0644 & 0.00393 & -0.0155 & 0.00321 & -0.00625 & 0.00906 & -0.0294 \\
\hline & $(0.0422)$ & $(0.0850)$ & $(0.0913)$ & $(0.100)$ & $(0.0910)$ & $(0.0833)$ & $(0.0810)$ \\
\hline \multirow[t]{2}{*}{$\gamma$} & $0.153^{* *}$ & 0.0341 & 0.124 & 0.177 & $0.265^{* *}$ & $0.294 * * *$ & $0.384 * * *$ \\
\hline & $(0.0681)$ & $(0.141)$ & $(0.140)$ & $(0.138)$ & $(0.109)$ & $(0.0934)$ & $(0.0861)$ \\
\hline$N$ & $1,662,467$ & $1,571,086$ & $1,502,833$ & $1,456,525$ & $1,413,182$ & $1,376,196$ & $1,341,907$ \\
\hline \multirow[t]{2}{*}{$R^{2}$} & 0.233 & 0.208 & 0.197 & 0.172 & 0.151 & 0.148 & 0.146 \\
\hline & \multicolumn{7}{|c|}{ Panel D: Specification with Zip-Level Fixed Effects } \\
\hline$\alpha$ & $\begin{array}{c}-0.631^{* * *} \\
(0.0512)\end{array}$ & $\begin{array}{c}-0.806 * * * \\
(0.0651)\end{array}$ & $\begin{array}{c}-0.817 * * * \\
(0.0577)\end{array}$ & $\begin{array}{c}-0.872^{* * *} \\
(0.0507)\end{array}$ & $\begin{array}{c}-0.745^{* * *} \\
(0.0535)\end{array}$ & $\begin{array}{c}-0.620 * * * \\
(0.0614)\end{array}$ & $\begin{array}{c}-0.434 * * * \\
(0.0755)\end{array}$ \\
\hline \multirow[t]{2}{*}{$\gamma$} & $0.347 * * *$ & $0.386^{* * *}$ & $0.402 * * *$ & $0.431^{* * *}$ & $0.403 * * *$ & $0.379 * * *$ & $0.312 * * *$ \\
\hline & $(0.0390)$ & $(0.0518)$ & $(0.0452)$ & $(0.0383)$ & $(0.0369)$ & $(0.0420)$ & $(0.0517)$ \\
\hline$N$ & $1,662,467$ & $1,571,086$ & $1,502,833$ & $1,456,525$ & $1,413,182$ & $1,376,196$ & $1,341,907$ \\
\hline$R^{2}$ & 0.230 & 0.205 & 0.195 & 0.170 & 0.150 & 0.147 & 0.145 \\
\hline
\end{tabular}

Note: See note to Table H.2. 
TABLE H.5: ALTERNATIVE SPECIFICATIONS WITH INCOME FROM CRISM, 2005 - ONWARDS USING INCOME FROM CRISM, ZIP CODE-LEVEL INEQUALITY

\begin{tabular}{|c|c|c|c|c|c|c|c|}
\hline & 2006 & 2007 & 2008 & 2009 & 2010 & 2011 & 2012 \\
\hline & \multicolumn{7}{|c|}{ Panel A: Inverse of Expected Income Replaces Rank } \\
\hline$\alpha$ & $\begin{array}{c}23,788^{* * *} \\
(1,109)\end{array}$ & $\begin{array}{c}26,955^{* * *} \\
(1,477)\end{array}$ & $\begin{array}{c}23,779 * * * \\
(1,531)\end{array}$ & $\begin{array}{c}24,348^{* * *} \\
(1,630)\end{array}$ & $\begin{array}{c}17,600 * * * \\
(1,660)\end{array}$ & $\begin{array}{c}7,291^{* * *} \\
(1,672)\end{array}$ & $\begin{array}{l}-1,136 \\
(1,700)\end{array}$ \\
\hline$\beta$ & $\begin{array}{c}0.235^{* * *} \\
(0.0128)\end{array}$ & $\begin{array}{c}0.217^{* * *} \\
(0.0179)\end{array}$ & $\begin{array}{c}0.213^{* * *} \\
(0.0186)\end{array}$ & $\begin{array}{c}0.224 * * * \\
(0.0194)\end{array}$ & $\begin{array}{c}0.191 * * * \\
(0.0195)\end{array}$ & $\begin{array}{c}0.111^{* * *} \\
(0.0194)\end{array}$ & $\begin{array}{c}0.0433 * * \\
(0.0193)\end{array}$ \\
\hline$\gamma$ & $\begin{array}{c}-13,978 * * * \\
(929.5)\end{array}$ & $\begin{array}{c}-13,527 * * * \\
(1,244)\end{array}$ & $\begin{array}{c}-12,524 * * * \\
(1,286)\end{array}$ & $\begin{array}{c}-13,532 * * * \\
(1,365)\end{array}$ & $\begin{array}{c}-12,297 * * * \\
(1,391)\end{array}$ & $\begin{array}{c}-7,409 * * * \\
(1,399)\end{array}$ & $\begin{array}{c}-4,101 * * * \\
(1,416)\end{array}$ \\
\hline $\begin{array}{l}N \\
R^{2} \\
\end{array}$ & $\begin{array}{c}1,515,257 \\
0.223 \\
\end{array}$ & $\begin{array}{c}1,398,167 \\
0.198 \\
\end{array}$ & $\begin{array}{c}1,313,470 \\
0.191 \\
\end{array}$ & $\begin{array}{c}1,255,442 \\
0.167 \\
\end{array}$ & $\begin{array}{c}1,199,727 \\
0.145 \\
\end{array}$ & $\begin{array}{c}1,152,689 \\
0.142 \\
\end{array}$ & $\begin{array}{c}1,108,681 \\
0.141 \\
\end{array}$ \\
\hline \multicolumn{8}{|c|}{ Panel B: Outcome is the Log of the Difference of Debt } \\
\hline$\alpha$ & $\begin{array}{c}-0.192 * * * \\
(0.0279)\end{array}$ & $\begin{array}{c}-0.189 * * * \\
(0.0356)\end{array}$ & $\begin{array}{c}-0.195^{* * *} \\
(0.0393)\end{array}$ & $\begin{array}{c}-0.233^{* * *} \\
(0.0467)\end{array}$ & $\begin{array}{c}-0.314^{* * *} \\
(0.0547)\end{array}$ & $\begin{array}{c}-0.293^{* * *} \\
(0.0593)\end{array}$ & $\begin{array}{c}-0.326 * * * \\
(0.0639)\end{array}$ \\
\hline$\beta$ & $\begin{array}{c}-0.0862 * * * \\
(0.0164)\end{array}$ & $\begin{array}{c}-0.103 * * * \\
(0.0211)\end{array}$ & $\begin{array}{c}-0.0919 * * * \\
(0.0233)\end{array}$ & $\begin{array}{c}-0.133^{* * *} \\
(0.0277)\end{array}$ & $\begin{array}{c}-0.173^{* * *} \\
(0.0320)\end{array}$ & $\begin{array}{c}-0.193 * * * \\
(0.0346)\end{array}$ & $\begin{array}{c}-0.217 * * * \\
(0.0372)\end{array}$ \\
\hline$\gamma$ & $\begin{array}{c}0.219 * * * \\
(0.0244)\end{array}$ & $\begin{array}{c}0.181^{* * *} \\
(0.0310)\end{array}$ & $\begin{array}{c}0.176^{* * *} \\
(0.0343)\end{array}$ & $\begin{array}{c}0.212 * * * \\
(0.0409)\end{array}$ & $\begin{array}{c}0.299 * * * \\
(0.0478)\end{array}$ & $\begin{array}{c}0.301^{* * *} \\
(0.0518)\end{array}$ & $\begin{array}{c}0.324 * * * \\
(0.0557)\end{array}$ \\
\hline$N$ & $1,578,281$ & $1,456,265$ & $1,367,972$ & $1,307,516$ & $1,249,511$ & $1,200,516$ & $1,154,700$ \\
\hline$R^{2}$ & 0.252 & 0.201 & 0.171 & 0.128 & 0.098 & 0.088 & 0.083 \\
\hline
\end{tabular}

Note: The estimated specification corresponds to the specification in Panel C in Table H.2. 
FIGURE H.1: THE ESTIMATED EFFECT OF ONE SD INCREASE IN INEQUALITY ON DEBT ACCUMULATION, 2005 ONWARDS USING INCOME FROM CRISM, ZIP CODE-LEVEL INEQUALITY

$\boldsymbol{\sigma}($ Inequality $) *(\boldsymbol{\beta}+\boldsymbol{\gamma} * \boldsymbol{R a n k})$

Panel A: Parsimonious Specification (Panel A in Table H.2)

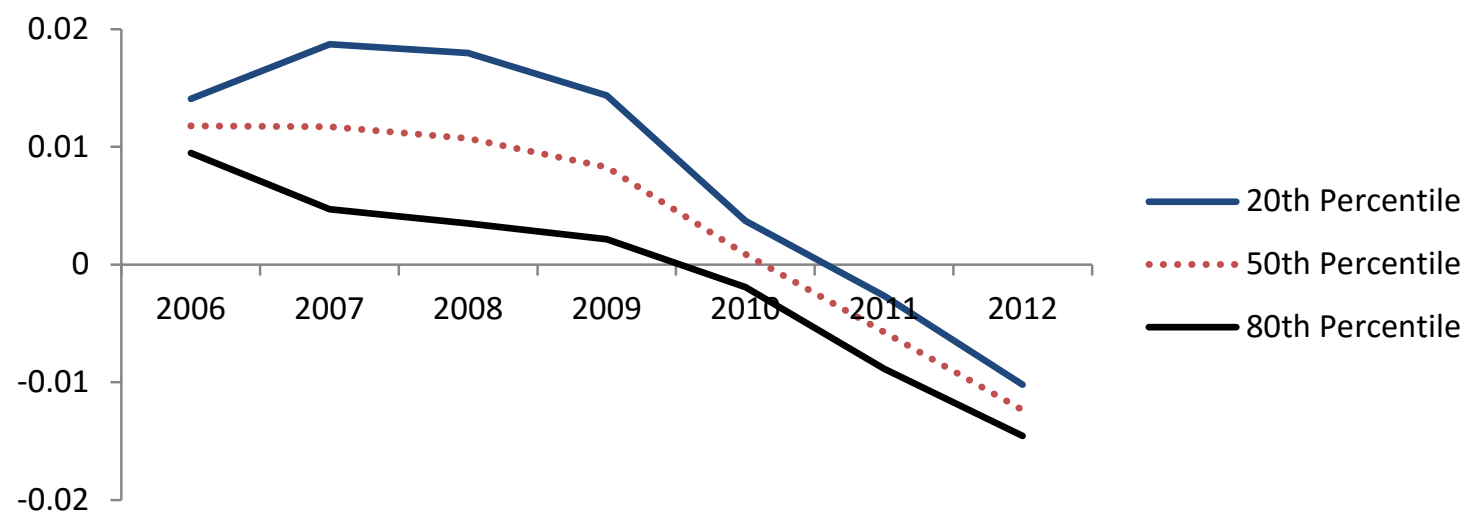

Panel B: Specification with Full Set of Controls (Panel C in Table H.2)

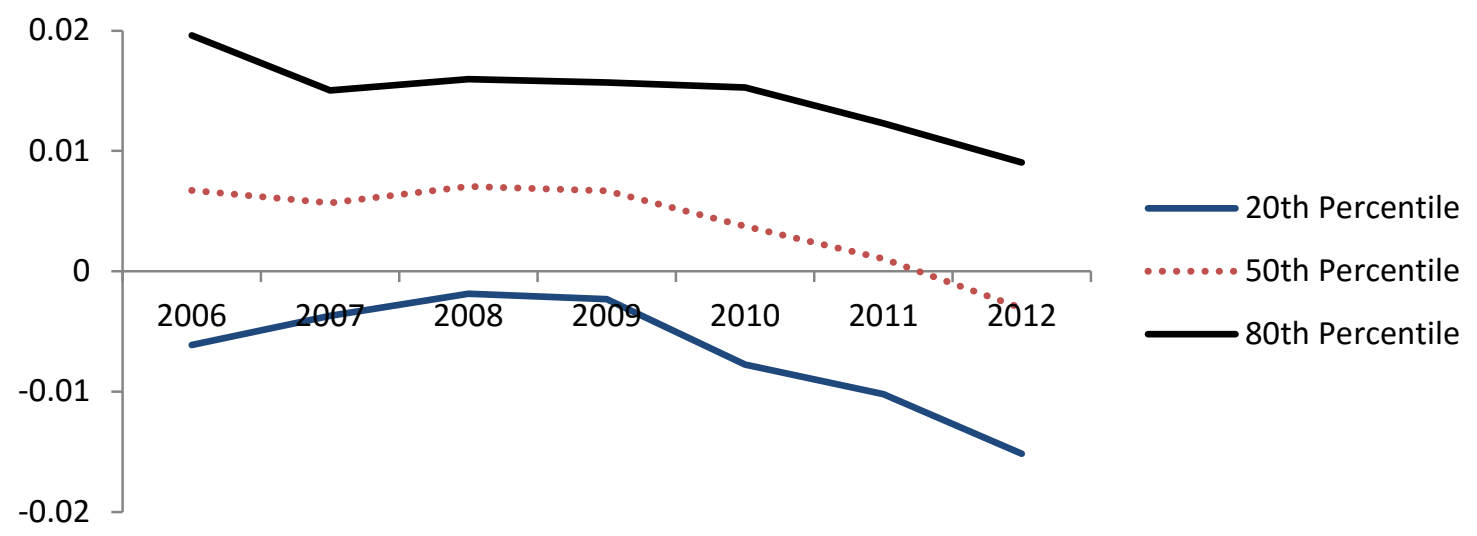

Panel C: Specification with Controls (Panel B in Table H.2)

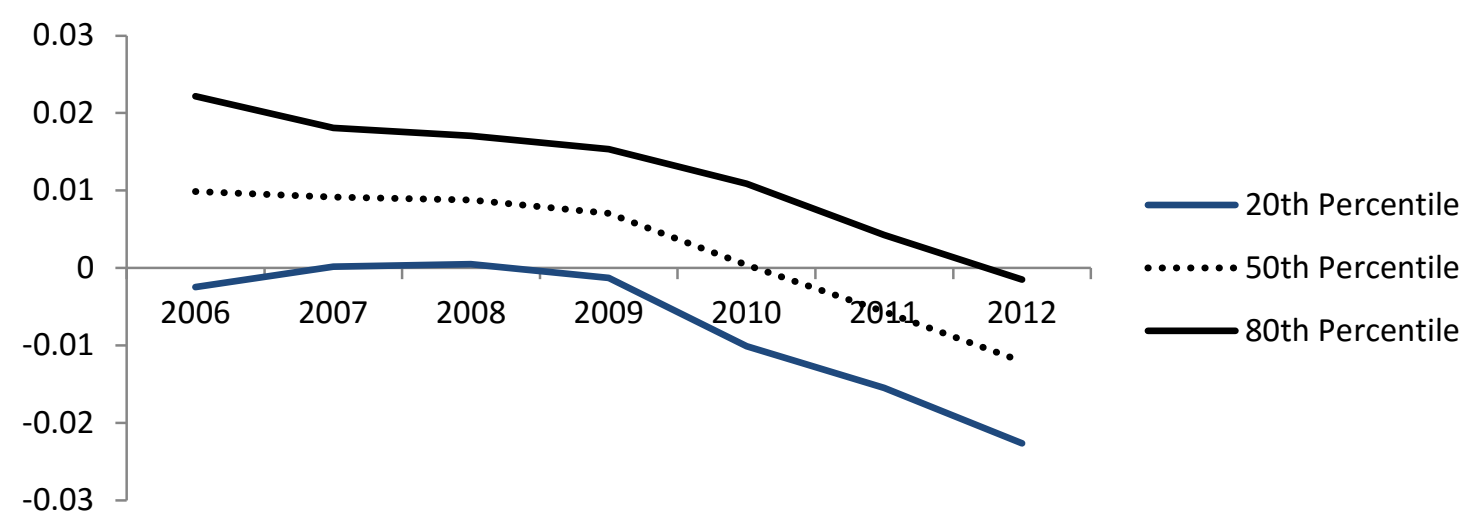

